Claudia Nery Teixeira-Palombo

\title{
Estado nutricional de crianças: conhecimentos e práticas de educadoras de uma creche
}

Dissertação apresentada à Escola de Enfermagem da Universidade de São Paulo para obtenção do título de mestre em Saúde Coletiva

Orientadora:

Profa. Dra. Elizabeth Fujimori 
Aos meus pais, Nilva e Cláudio, por tudo o que me ensinaram. Aos meus irmãos, Eretuza, Fabiana e Danilo por tudo que compartiᄃhamos e aprendemos juntos. Ao meu marido, Cleber, pela paciência, incentivo e apoio em todos os momentos. Aos filhinhos que certamente virão, pela motivação e inspiração. 


\section{Agradecimentos}

Esse trabalho foi realizado graças ao incentivo, torcida, oração, colaboração, compreensão e dedicação de várias pessoas, às quais quero agradecer nesse momento:

À todos os meus familiares que mesmo de longe torceram e rezaram para a conclusão de mais uma etapa da minha vida.

À querida amiga Ivani Roma, que permitiu meu ingresso no curso de mestrado, suportando as dificuldades e incentivando-me sempre a continuar meu caminho.

Aos colegas de trabalto da unidade de saúde Santa Luzia que agüentaram firme minhas ausências, apoiando-me nos momentos de maior dificuldade.

À todos os funcionários da creche do Pq. São Jorge, especialmente à Irene e Vanessa, que me receberam com muito entusiasmo e contribuíram muito em todas as etapas do desenvolvimento desse trabalho.

À todas as crianças, mães e pais da creche Pq. São Jorge, que com muita paciência participaram das reuniões, entrevistas, colaborando muito para o desenvolvimento desse estudo.

À Profa. Maria De La Ó Veríssimo e á Profa. Cássia Baldini que contribuíram com sugestões valiosas para o encaminhamento do trabalho.

À todos os professores e funcionários do departamento de Saúde Coletiva que me acolheram com muito carinho e torceram por mim.

Enfim, a todos aqueles que direta ou indiretamente tenham contribuido para a realização desse trabalho, muito obrigado!! 


\section{Agradecimento Especial}

À Profa. Elizabeth Fujimori que me recebeu com muito carinho e entusiasmo, direcionou o trabalho com muita paciência, conduzindo-me suavemente pelo caminho do saber, respeitando minhas limitações e dificuldades.

Muito Obrigada!! 
Cada pessoa pensa como pode...

(Mário Quintana) 


\section{SUMÁRIO}

RESUMO

ABSTRACT

APRESENTAÇÃO

1 INTRODUÇÃO.

1.1 A creche como equipamento social de promoção à saúde infantil

1.2 Panorama das deficiências nutricionais na infância

1.3 A desnutrição energético-protéica

1.4 A Anemia por deficiência de ferro

\section{PRESSUPOSTOS E QUESTÕES DA PESQUISA}

\section{OBJETIVOS}

3.1 Geral

3.2 Específicos

\section{METODOLOGIA}

4.1 Desenho da pesquisa

4.2 Local do estudo

4.3 População do estudo

4.4 Coleta de dados

4.5 Avaliação do estado nutricional

4.6 Procedimentos ético-legais

4.7 Sistematização e análise dos dados

\section{APRESENTAÇÃO E DISCUSSÃO DOS RESULTADOS}

5.1 Caracterização dos sujeitos da pesquisa

5.1.1 Caracterização das crianças

5.1.2 Caracterização das educadoras

5.2 Principais problemas de saúde na creche

5.3 Conhecimentos e práticas das educadoras em relação à desnutrição

5.4 Conhecimentos e práticas das educadoras em relação à anemia

\section{CONSIDERAÇÕES FINAIS}

\section{REFERÊNCIAS BIBLIOGRÁFICAS}

\section{ANEXOS}




\section{LISTAS}

\section{Lista de Mapas}

Mapa 1. Localização do Distrito do Lajeado

Mapa 2. Mapa da exclusão social da cidade de São Paulo

\section{Lista de Tabelas}

Tabela 1. Distribuição das crianças segundo variáveis sócio-econômico-demográficas e de saúde

Tabela 2. Distribuição das crianças segundo presença de doenças e sintomas referidos nos quinze dias anteriores à entrevista

Tabela 3. Distribuição das crianças quanto ao estado nutricional caracterizado segundo escore $\mathrm{Z}$ de peso/idade, peso/altura e altura/idade

Tabela 4. Distribuição das crianças segundo dados sobre o estado nutricional de ferro

\section{Lista de Quadros}

Quadro 1. Distribuição das crianças por turma/faixa etária e número de educadoras

Quadro 2. Distribuição das educadoras de creche segundo características gerais

Quadro 3. Questões norteadoras e temas relacionados aos conhecimentos e

práticas das educadoras em relação à desnutrição

Quadro 4. O que é desnutrição?

Quadro 5. Causas da desnutrição

Quadro 6. Conseqüências da desnutrição

Quadro 7. Reconhecimento da desnutrição nas crianças

Quadro 8. Como aprendeu sobre a desnutrição

Quadro 9. O que faz quando identifica uma criança com desnutrição

Quadro 10. O que fazer para combater a desnutrição na comunidade

Quadro 11 Questões norteadoras e temas relacionados aos conhecimentos e

práticas das educadoras em relação à anemia

Quadro 12. O que é anemia?

Quadro13. Causas da anemia

Quadro14. Conseqüências da anemia 
Quadro 15. Reconhecimento da anemia nas crianças

Quadro 16. Como aprendeu sobre a anemia

Quadro 17. O que faz quando identifica uma criança com anemia?

Quadro 18. O que fazer para combater a anemia na comunidade? 


\section{Catalogação na publicação (CIP) Biblioteca "Wanda de Aguiar Horta" da EEUSP}

\section{Teixeira-Palombo, Claudia Nery}

Estado nutricional de crianças: conhecimentos e práticas de educadoras de uma creche. / Claudia Nery Teixeira-Palombo. - São Paulo: C.N. Teixeira-Palombo, 2005.

$96 \mathrm{p}$.

Dissertação (Mestrado) - Escola de Enfermagem da Universidade de São Paulo.

Orientadora: Profa. Dra. Elizabeth Fujimori

1. Enfermagem 2. Saúde da criança 3. Estado nutricional

4. Desnutrição infantil 5. Anemia 6. Creches

I. Título. 
Teixeira-Palombo CN. Estado nutricional de crianças: conhecimentos e práticas de educadoras de uma creche. [dissertação]. São Paulo (SP): Escola de Enfermagem da Universidade de São Paulo; 2005.

\section{RESUMO}

Alimentação e nutrição constituem requisitos básicos para a promoção, proteção e recuperação da saúde. A creche representa um equipamento social importante para a promoção da saúde da criança e pode ser uma aliada das unidades de saúde no combate às principais deficiências nutricionais, como a desnutrição e a anemia, que exercem efeitos deletérios à saúde da criança. Com a finalidade de levantar dados para subsidiar propostas de intervenção para prevenir, detectar e controlar esses problemas nutricionais, este estudo, aprovado por Comitê de Ética em Pesquisa, teve como objetivo, caracterizar as condições de saúde e nutrição de crianças e identificar e analisar conhecimentos e práticas de educadoras de uma creche relativos à desnutrição e à anemia. O estado nutricional foi caracterizado utilizando-se dados antropométricos e de palidez palmar, além de resultados recentes de exame de sangue. Os índices peso/idade, altura/idade e peso/altura foram utilizados para caracterizar o estado nutricional e identificar desnutrição (<-2 escore Z) e a palidez palmar e/ou $\mathrm{Hb}<11 \mathrm{~g} / \mathrm{dL}$ foram utilizados para identificar anemia. Os dados sobre os conhecimentos e as práticas das educadoras foram obtidos por entrevistas transcritas na íntegra e submetidas à análise de conteúdo. Participaram do estudo 149 crianças de 0 a 5 anos; $86,4 \%$ freqüentavam a creche por mais de 6 meses; $2 / 3$ pertenciam a famílias com renda per capita $<0,5$ salário mínimo e $84,9 \%$ estavam cadastradas em alguma unidade de saúde da família do bairro. Mais da metade das crianças haviam apresentado problema de saúde nos últimos 15 dias. A desnutrição foi pouco freqüente: $2,7 \%$ das crianças apresentaram déficit de peso/idade, $2,0 \%$ déficit de altura/idade e $0,7 \%$ déficit de peso/altura, porém a anemia foi encontrada em 43,3\% das crianças. Foram entrevistadas 15 educadoras com idade média de 28 anos, todas com o segundo grau de escolaridade completo. A maioria não tinha experiência anterior de trabalho em creche e não havia recebido nenhum treinamento específico. Para a maioria das educadoras, desnutrição era representada por crianças pequenas, com atraso no desenvolvimento e sempre doentes; causada por má alimentação e falta de acompanhamento de saúde; tendo como principal conseqüência o retardo no desenvolvimento. A anemia foi definida como "sangue fraco", crianças pálidas e hipoativas; causada por má alimentação; tendo como consequiência a leucemia. Estimular a alimentação e a participação nas atividades foram as práticas relatadas para minimizar as conseqüências desses agravos. Na concepção das educadoras, informação, alimentação e acompanhamento de saúde são medidas fundamentais para o controle da desnutrição e da anemia. Evidenciou-se que os conhecimentos e as práticas foram adquiridos no dia a dia, pela vivência de cuidar de crianças na creche e em casa. Embora fossem capazes de identificar algumas crianças com problemas nutricionais e procurassem contribuir para a promoção da saúde, atribuíam aos profissionais e serviços de saúde a responsabilidade por tais ações, não sendo capazes de relacionar com as condições e práticas do cuidado cotidiano na creche, de sua competência. O estudo aponta a necessidade de se incluir conhecimentos sobre processo saúde-doença, especialmente anemia e práticas de cuidados com as crianças, tanto na formação inicial quanto continuada dos educadores infantis. Ao mesmo tempo indica a importância da parceria entre unidades locais de saúde e creches para a promoção da saúde da criança.

Descritores: enfermagem, saúde da criança, estado nutricional, desnutrição infantil, anemia, creche. 
Teixeira-Palombo CN. Child nutritional status: knowledge and practice of child educators day-care center. [dissertation]. São Paulo: Nursing School of São Paulo University; 2005.

\begin{abstract}
Food and nutrition constitute basic requisitions to the promotion, protection and rehabilitation of health. The day-care center is important social equipment for the promotion of the children's health and, therefore, it can be an ally of the units of health to combat of nutrition deficiencies. The purpose of this study, approved by Research Ethic's Committee, was subsidized intervention's proposals to prevent, to detect and to control more common nutritional problems. The objective was to characterize the children health and nutritional conditions and to analyze the educators of a day-care center's knowledge and practice relative to malnutrition and anemia. The indicators weight/age, height/age and weight/height were used to characterize the nutritional condition and to identify malnutrition ( $<-2$ escore $\mathrm{Z}$ ) and the palm's pallor and/or $\mathrm{Hb}<11 \mathrm{~g} / \mathrm{dL}$ were used to identify anemia. The data about the knowledge and the practice ones of the educators have been gotten by interviews integrally transcribed and submitted to the content analysis. Hundredforty-nine children between zero and five years old participated of the study: $86.4 \%$ frequented the day-care center for more than 6 months; $2 / 3$ belonged to families with lesser per capita income than $1 / 2$ wage and $84.9 \%$ were registered in some quarter's family's unit of health. More of half the children have been presented health's problems in the last 15 days. The malnutrition was not very frequent: $2.7 \%$ of the children presented deficit of weight/age and $2.0 \%$ deficit of height/age. Just $0.7 \%$ of the children presented deficit of weight and height, but the anemia was found in $43.3 \%$ of the children. Fifteen educators with age around twenty-eight years participated of the study, all they with the complete scholar second rank. The majority had no anterior experience of working in a day-care center and did not have received any specific training. The malnutrition was represented by small children, with delay in the development and always sick; it is caused by bad alimentation and lack of health accompaniment; it has as main consequence the retard in the development. The anemia mentions to "weak blood"; pale and hypoactive children; it is caused by harm-feeding and it has as consequence the leukemia. The related practice to minimize the consequences of these problems was stimulating alimentation and participation in activities. In the educators' conception, information, alimentation and accompaniment of health are fundamental steps for the control of the malnutrition and the anemia. It was proven that the practices and knowledge were originated from the common sense and the proper experience of the educators. Although were able to identify some children with nutritional problems and wanted contribute to health promotion, attribute to professionals and health's services the responsable of that actions, has not been able to relate with the conditions and pratices of the everyday care in the child care. The study aim the necessity to include knowledge about the process health-disease, specially anemia and pratices of care with children, as initial education as continued of the child educators. At the same time aim the importance of the partnership among locals health's units and day care centers to promote child's health.
\end{abstract}

Descriptors: nursing, child's health, nutritional condition, malnutrition, anemia, day-care center. 
Apresentação 


\section{APRESENTAÇÃO}

Como enfermeira de uma unidade de saúde do Programa de Saúde da Família, localizada em região periférica do município de São Paulo, observamos que os problemas relacionados à alimentação e nutrição infantil conferem grande demanda na rotina do atendimento de enfermagem.

A orientação relacionada à alimentação infantil é realizada desde o atendimento à gestante no pré-natal, com o incentivo ao aleitamento materno, e em seguida no acompanhamento da saúde da criança, em que são realizadas orientações sistemáticas sobre a importância da manutenção do aleitamento materno exclusivo nos primeiros 6 meses e também sobre a importância da introdução adequada e oportuna da alimentação complementar, assim como a melhor forma para se alimentar uma criança e como lidar com os principais problemas na infância, como a falta de apetite, constipação intestinal, entre outras.

Além disso, é comum o atendimento de crianças desnutridas e/ou anêmicas que requerem orientação mais específica e acompanhamento periódico. Acreditamos que esses problemas nutricionais sejam comuns nessa unidade de saúde por sua localização em região de forte exclusão social.

Buscar mais informações e conhecimentos na área de alimentação e nutrição infantil para aprender a lidar com tais situações nos motivaram a ingressar num curso de especialização em desnutrição energético-protéica.

O curso nos motivou a levantar dados sobre o perfil nutricional das crianças atendidas para obter um diagnóstico e planejar as ações de intervenção. Assim, em meados de 2002, um levantamento feito a partir de anotações em prontuários das crianças atendidas na unidade mostrou que cerca de $10 \%$ das crianças menores de 5 
anos apresentavam algum grau de desnutrição, e aproximadamente $36 \%$ apresentavam anemia.

Esse resultado mostrou que somente um atendimento individualizado na unidade de saúde era insuficiente para combater as deficiências nutricionais, pois a recuperação dessas crianças depende muito mais das condições de vida e trabalho a que estão inseridas suas famílias, isto é, das condições de acesso à alimentação adequada, higiene, saneamento e cuidados que recebem, tanto em casa quanto nos ambientes coletivos em que passam a maior parte do dia, tais como creches e pré-escolas.

Ações integradas entre o serviço de saúde e os equipamentos sociais disponíveis na comunidade foram alternativas pensadas para minimizar esses problemas. O primeiro passo foi sensibilizar a equipe quanto ao problema detectado, promovendo momentos de educação continuada com os agentes comunitários de saúde e os auxiliares de enfermagem sobre o assunto. Ao mesmo tempo, foram feitos contatos com a igreja local e com o grupo da pastoral da criança, com a promoção de curso de treinamento e formação de líderes comunitários. A creche foi outro equipamento social contatado na busca da resolução dos problemas detectados, uma vez que cerca de $70 \%$ das crianças cadastradas no posto eram matriculadas na creche localizada na área de abrangência.

O ingresso no curso de pós-graduação na área da enfermagem em saúde coletiva despertou-nos para a importância do trabalho embrionário que realizávamos na creche, pois compreendemos a necessidade da participação da unidade de saúde nas redes sociais locais, para o planejamento e desenvolvimento de ações intersetoriais que, segundo o Ministério da Saúde, é um dos princípios norteadores para o cuidado integral da saúde da criança.

Conhecendo a creche, os funcionários e as crianças, surgiram alguns questionamentos relacionados aos cuidados prestados pelas educadoras em relação à 
alimentação e acompanhamento do crescimento e desenvolvimento das crianças: como as educadoras lidam com crianças desnutridas/anêmicas? Essa questão surge a partir da observação de que crianças com problemas de saúde tais como febre, diarréia ou vômito são encaminhadas à unidade de saúde, porém não crianças com desnutrição ou anemia. Assim, surgiram outras questões como, será que não há criança desnutridas ou anêmicas na creche? Ou será que as educadoras não conseguem identificar tais crianças? Que conhecimentos as educadoras têm a respeito desses problemas? Será que sabem como cuidar dessas crianças adequadamente?

Apresenta-se assim uma preocupação: se as educadoras não sabem o que representam esses problemas para as crianças, como elas vão cuidar dessas crianças adequadamente? Não que seja uma obrigação que elas saibam o que é desnutrição ou anemia, mas se já foi detectado um número expressivo dessas deficiências nas crianças da área de abrangência, se a creche atende cerca de $70 \%$ dessa população, não é possível que não exista crianças desnutridas e /ou anêmicas na creche.

A partir daí, colocamos como objeto desse estudo os conhecimentos e as práticas das educadoras da creche em relação à desnutrição e anemia, com a finalidade de utilizarmos os resultados para subsidiar ações de intervenção para o combate dessas deficiências nutricionais na comunidade. 
Introdução 


\section{INTRODUÇÃO}

A alimentação e a nutrição constituem requisitos básicos para promoção, proteção e recuperação da saúde, especialmente quando se trata da população infantil.

Nos países pobres, como é o caso do Brasil, as condições de vida desfavoráveis propiciam inúmeros problemas de saúde, sobretudo relacionados à alimentação e à nutrição, destacando-se a desnutrição energético-protéica e a anemia ferropriva como os de maior importância epidemiológica na infância.

A necessidade do controle dessas deficiências nutricionais, no âmbito da saúde coletiva, decorre da influência decisiva que tanto a desnutrição quanto a anemia exercem sobre a saúde infantil, especialmente pelo conhecimento de seus efeitos deletérios na qualidade de vida, na morbidade e na mortalidade das crianças menores de cinco anos (WHO, 1995; Freire, 1997; Halpern et al., 2000; Guardiola et al., 2001; Caldeira et al., 2001).

Embora a erradicação completa das deficiências nutricionais dependa da superação dos grandes contrastes econômicos e sociais gerados e mantidos pelo processo de produção e distribuição de bens e serviços (Laurell, 1983; Campino, 1986; Martins et al., 1987; Goldenberg, 1989; Szarfarc et al., 1995), ações específicas do setor saúde, sobretudo da atenção primária, podem contribuir para melhorar o quadro epidemiológico dessas deficiências (Batista Filho \& Rissin, 1993).

Na atenção primária, o Programa de Saúde da Família (PSF) lançado pelo Ministério da Saúde, em 1994, como estratégia de reorganização dos serviços básicos de saúde necessária para o fortalecimento do Sistema Único de Saúde, prioriza ações de promoção, proteção e recuperação da saúde de forma integral e contínua. Chiesa (2000), ao discutir a promoção da saúde como eixo estruturante do PSF, destaca o 
fortalecimento da atuação intersetorial. A agenda de compromissos do Ministério da Saúde (2004) para a Saúde Integral da Criança e Redução da Mortalidade Infantil aponta como primeiro princípio norteador do cuidado na saúde da criança, o planejamento e desenvolvimento de ações intersetoriais, incluindo nesse aspecto, a articulação da unidade de saúde com creches e pré-escolas.

O projeto "Com Gosto de Saúde", desenvolvido nas escolas no município do Rio de Janeiro, RJ desde 2000, demonstra uma articulação do setor saúde com a educação, enfocando a alimentação/nutrição como componente fundamental da promoção da saúde nas escolas (Maldonado et al., 2002).

Em Curitiba, PR, a intersetorialidade tem sido apontada como importante estratégia para sustentabilidade das políticas públicas de promoção da saúde no Movimento das Cidades Saudáveis (Moysés et al., 2004).

Assim, observa-se que a intersetorialidade tem sido foco de diversos trabalhos no campo da saúde coletiva, mostrando que cada comunidade pode contribuir com suas especificidades, articulando ou produzindo novas ações com vistas à promoção da saúde (Castro et al., 2002; Maldonado et al., 2002; Silva, 2002; Zancan \& Bodstein, 2002; Nobre, 2003; Moysés et al., 2004; Paula et al., 2004).

Tendo em vista essas considerações, este estudo tomou como objeto, conhecimentos e práticas de educadoras infantis em relação ao estado nutricional de crianças.

\subsection{A creche como equipamento social de promoção à saúde infantil}

O Ministério da Saúde (1989) define creche como "uma instituição social, dentro de um contexto de socialização complementar ao da família, que deve proteger e 
propiciar cuidados diurnos integrais de higiene, alimentação, educação e saúde, em clima afetivo, estimulante e seguro às crianças sadias de 3 meses a 4 anos".

Historicamente as creches estão vinculadas a uma postura assistencialista e de atendimento somente de crianças de famílias de baixa renda. Entretanto, como resultado de transformações econômicas e ideológicas da sociedade brasileira, tem aumentado muito a demanda por estes serviços em função do número cada vez maior de mulheres que ingressam no mercado de trabalho. Isto se reflete, por exemplo, na crescente ampliação do número de creches e escolas maternais particulares que se tem observado em todas as classes sociais (Vitória \& Rossetti-Ferreira, 1993).

Nos últimos anos, a literatura científica sobre educação infantil incorpora a necessidade de integrar o cuidar e o educar na busca da superação do preconceito em relação ao ato de apenas cuidar, que surgiu quando a creche foi reconhecida como espaço educativo (Maranhão, 2000b). Assim, parece ser uma questão de consenso o fato de que não basta um atendimento que garanta apenas assistência e/ou custódia de crianças (Vitória \& Rossetti-Ferreira, 1993).

Um reflexo dessa mudança de postura foi a inclusão da creche no capítulo da Educação, na Constituição Nacional de 1988 e no Projeto Lei de Diretrizes e Bases da Educação, atualmente em discussão (Brasil, 1988; 1996). Nesses documentos, a creche passa a ser definida como "direito da criança, opção da família e obrigação do estado".

A inclusão da creche no sistema educativo representa um importante avanço nos programas destinados a essa faixa etária, pois representa a superação do caráter assistencialista predominante nesses programas e impõem a necessidade de formulação de uma política nacional de educação, estabelecendo diretrizes básicas para a implantação e desenvolvimento de programas de creche e pré-escolas no Brasil (Haddad, 1991). Apesar dessa incorporação ao sistema de ensino, as creches são 
instituições nas quais o cuidado à criança é inerente às atividades desenvolvidas, sobretudo com as crianças menores (Rezende \& Silva, 2002).

Nesse contexto, o educador assume um papel importantíssimo e, para que desenvolva um trabalho de qualidade, é necessário um investimento sério na sua formação, tanto inicial, quanto continuada no serviço.

Veríssimo et al. (2003), com o intuito de apreender as representações de trabalhadoras de creches de uma universidade pública do município de São Paulo, SP, acerca do cuidado da criança, constataram que para as trabalhadoras, cuidado era definido como atendimento às necessidades físicas e emocionais da criança, constituindo etapa preliminar às atividades pedagógicas e como momento de aprendizado, necessitando assim de capacitação e habilitação específica.

Carmo (2004) coloca que cuidar e educar crianças pequenas em instituições coletivas é tarefa para um profissional, que portanto necessita de formação prévia que contemple conhecimentos sobre esse duplo objetivo, formação em serviço, espaço e instrumentos de trabalho adequados.

No Brasil, levantamento sobre o perfil do magistério da educação básica revelou que $14,9 \%$ dos professores de pré-escola de todo país não possuíam primeiro grau completo (MEC, 1997).

Estudando o perfil de creches numa cidade do sul do país, Barros et al. (1999) encontraram uma grande parcela de creches públicas com educadoras de baixa escolaridade, isto é, $48 \%$ das creches públicas possuíam educadoras com o primeiro grau incompleto. Assim, destaca como prioridade, um maior nível de escolaridade das educadoras para melhor assistência às crianças. A esse respeito, Maranhão (2000a) 
ressalta a importância de incluir nos currículos de formação inicial ou continuada dos educadores, conhecimentos sobre o processo saúde-doença.

Em se tratando de crianças que freqüentam creches, uma outra questão também deve ser considerada, a que se relaciona com o desenvolvimento de morbidades em ambientes coletivos. Estudos mostram que crianças freqüentadoras de creches adoecem mais por infecções respiratórias e diarréias que as crianças cuidadas exclusivamente em casa, sobretudo quando esses agravos estão associados a déficits nutricionais (Fuchs et al., 1996; Amaral et al., 1997; Fonseca et al., 1997; Barros, 1999; Prado et al., 2002).

Apesar de constituir ambientes que favoreçam maior incidência de doenças infecciosas, as creches também têm sido apontadas como fator de proteção para as crianças, em relação ao seu estado nutricional (Siviero et al., 1997; Correa et al., 1999).

Taddei et al. (2000) acompanharam 180 crianças usuárias de creche durante 9 meses com a finalidade de avaliar a eficácia da freqüência à creche em promover a recuperação nutricional das crianças. O estudo demonstrou que o percentual de crianças em risco nutricional diminuiu no decorrer do acompanhamento, passando de 10,1\% para 3,4\% em relação ao índice peso/estatura, enquanto para os índices peso/idade e altura/idade, a queda foi de $29,8 \%$ para $15,2 \%$ e de $50 \%$ para $44,8 \%$, respectivamente, sendo necessários aproximadamente 4 meses para que esses benefícios fossem identificados.

Em Cuiabá, MT, Brunken et al. (2002), estudando a prevalência de anemia em crianças menores de 36 meses freqüentadoras de creches públicas, encontraram uma prevalência estatisticamente menor de anêmicos no grupo de crianças que haviam ingressado na creche há mais de 4 meses. 
Partindo da premissa de que para promover a saúde integral das crianças é importante prevenir, acredita-se que a creche constitui um local propício para se efetivar práticas preventivas.

Assim, cabe aos serviços de saúde e profissionais engajados na área da saúde coletiva trabalhar em conjunto com os equipamentos sociais, tais como creches, de forma a promover a saúde da criança.

\subsection{Panorama das deficiências nutricionais na infância}

Estimativas da OMS (WHO, 1997) indicam que nos países pobres 38,1\% das crianças menores de cinco anos apresentam comprometimento severo do crescimento linear (stunting) e 9,0\% sofrem de emagrecimento extremo (wasting). Dados mundiais também mostram que a desnutrição está envolvida com 55\% das mortes infantis nesses países (Unicef, 1998).

No Brasil, estudos de abrangência nacional realizados nas últimas décadas têm demonstrado tendências expressivas de declínio na prevalência de déficits de altura em menores de cinco anos: de $32 \%$ na década de 70 as prevalências caíram para 15,4\% e 10,5\% nas décadas de 80 e 90, respectivamente (Monteiro et al., 2000a).

Esses dados revelam que a desnutrição tornou-se um problema nutricional de menor relevância, porém, estudos pontuais mostram que nas regiões mais pobres do país, a desnutrição continua a apresentar uma prevalência elevada, da mesma forma que em algumas áreas excluídas a prevalência pode ser superior a $20 \%$ entre os menores de cinco anos, mostrando-se ainda muito significativa do ponto de vista epidemiológico (Reichenheim \& Harpham, 1990; Marins et al., 1995; Santos et al., 1995; Soares et al., 2001). 
O estudo de Reichenheim \& Harpham (1990), realizado na favela da rocinha no Rio de Janeiro, RJ, avaliou o perfil nutricional de 591 crianças das quais 23,9\% delas apresentavam desnutrição leve e $22,0 \%$ desnutrição moderada, de acordo com a classificação de Gómez, evidenciando que a desnutrição ainda está muito presente nas áreas de maior exclusão social, mesmo em região desenvolvida.

Diferentemente do que vem ocorrendo com a desnutrição, a anemia ferropriva tem apresentado aumento significativo nas últimas décadas (Torres et al., 1994a; Monteiro et al., 2000b; Neuman et al., 2000; Soares et al., 2000; Silva et al., 2001; Brunken et al., 2002; Silva et al., 2002; Oliveira et al., 2002; Miranda et al., 2003). Atualmente tem sido considerada a deficiência nutricional de maior magnitude, estimando-se que sua prevalência afeta em torno de um terço de toda a população mundial (DeMaeyer \& Tegman, 1985; WHO, 1996).

Na cidade de São Paulo, SP, análise da tendência secular da anemia realizada por Monteiro et al. (2000b) revela que a prevalência da anemia entre as crianças com menos de 5 anos aumentou de $22,7 \%$ na década de 70 para 35,6\% na década de 80 e 46,9\% na década de 90, afetando especialmente as crianças dos estratos sócioeconômicos mais baixos da população.

Vale destacar também o estudo de Torres et al. (1994a), que envolveu 63 municípios do estado São Paulo e verificou que 59,1\% das crianças menores de 2 anos, atendidas nos serviços estaduais de saúde estavam anêmicas, sendo que 25,1\% delas apresentavam anemia grave. $\mathrm{O}$ estudo reiterou a relação existente entre a anemia e a desnutrição, constatando presença de anemia em 61,9\% das crianças com desnutrição leve e em 73,6\% das crianças com desnutrição moderada e grave. 
Com base nessas informações, é certo que a desnutrição e a anemia constituem problemas nutricionais que exigem prioridade para definição de estratégias de combate e controle.

É importante considerar também que no âmbito dos distúrbios nutricionais, um outro problema vem ganhando destaque, a obesidade. Embora este estudo não tenha a pretensão de abordar essa problemática, reconhece-se que a obesidade vem apresentando uma evolução crescente entre todas as faixas etárias e camadas sociais da população, e seus danos à saúde são tão deletérios quanto os provocados pela desnutrição e anemia (Monteiro et al., 2000c).

\subsection{A desnutrição energético-protéica}

A desnutrição energético-protéica é definida por Gómez (2003) como a assimilação insuficiente de alimentos pelo organismo, conduzindo a um estado patológico de diferentes intensidades e manifestações clínicas.

Várias classificações do estado nutricional têm sido propostas, baseadas nos índices antropométricos peso/idade, altura/idade e peso/altura. O Comitê de Especialistas para o assunto da Organização Mundial da Saúde (OMS) recomenda a adoção do escore $\mathrm{Z}$ como parâmetro de avaliação do estado nutricional da criança, adotando como nível de corte -2 escore $\mathrm{Z}$ para definir desnutrição energético-protéica. Esse ponto de corte é útil nos países onde a prevalência é elevada, pois diminui os riscos de falsos positivos, identificando as crianças com maior probabilidade de serem desnutridas (WHO, 1995).

É certo que numa população normal existem indivíduos naturalmente magros ou baixos devido à constituição genética, porém a proporção desses indivíduos em uma população sadia é muito pequena, isto é, cerca de $2,5 \%$. Portanto, quando o número de 
crianças baixas e/ou magras é elevado, certamente existem fatores que estão impedindo o pleno desenvolvimento do potencial genético (Brasil, 2001).

No Brasil, a desnutrição representa o efeito cumulativo das condições desfavoráveis de alimentação e está aliada ao acesso limitado a bens e serviços essenciais como saneamento, serviços de saúde e educação que, na verdade, refletem a realidade social do país (Bittencourt \& Magalhães, 1999).

Nos últimos 50 anos, vários modelos foram desenvolvidos para explicar a prevalência da desnutrição energético-protéica na população. Os primeiros modelos propunham uma única causa para a desnutrição, que seria representada pela má alimentação. Mais tarde, esse modelo unicausal foi superado pelo referencial teórico da multicausalidade, que pressupõe uma história natural para os processos mórbidos, considerando como determinantes do problema, variáveis biológicas, demográficas, socioeconômicas e mesmo de ordem estrutural (políticas estatais de desenvolvimento econômico e social), com o mesmo peso causativo e sem qualquer hierarquia. No final da década de 60, toma corpo a compreensão de que o processo saúde-doença é determinado socialmente, ou seja, de que formas de trabalhar e de viver geram potenciais de benefícios e de riscos, que se expressam no coletivo e nos indivíduos que o compõem através da saúde e sobrevivência e do adoecimento e morte (Facchini, 1995).

Nesse sentido, o social, antes subsidiário aos fenômenos biológicos, passa a se constituir no filtro através do qual se apresentam os fenômenos biológicos - e nutricionais - justificando, por assim dizer, a dimensão social da ocorrência das doenças e, conseqüentemente, a sua determinação social (Goldenberg, 1989).

As crianças desnutridas são mais vulneráveis à agressão dos agentes infecciosos, uma vez que a má nutrição diminui a resistência do organismo (Rivera \& Martorell, 
1988a, b; Woodward, 2001), o que também eleva a taxa de mortalidade infantil (Puffer \& Serrano, 1973; WHO, 1995). Associado ao déficit de crescimento e emagrecimento, também destaca-se o retardo no desenvolvimento psicomotor, a dificuldade no aproveitamento escolar, a diminuição da estatura e da capacidade produtiva na idade adulta (Paine \& Lisboa, 1976; Nóbrega, 1981; Lei et al., 1995; Guardiola et al., 2001).

Em relação ao retardo do crescimento, no sexo feminino o problema está associado ao efeito inter-gerações da desnutrição, ou seja, o retardo do crescimento na infância tem como resultado mulheres adultas com baixa estatura, que apresentam maior probabilidade de gerar crianças com baixo peso ao nascer. Estas, por sua vez, estão sujeitas a maior risco de apresentar retardo no crescimento e também gerar recémnascidos de baixo peso (Nóbrega, 1981).

A prevenção da desnutrição por meio de ações de promoção da saúde ainda representa uma das melhores alternativas de combate da desnutrição que pode ser promovido pelos serviços de saúde, destacando-se entre elas: acompanhamento prénatal, vigilância do crescimento da criança, incentivo ao aleitamento materno, educação nutricional e proteção às infecções comuns na infância.

\subsection{Anemia por deficiência de ferro}

A Organização Mundial da Saúde define a anemia nutricional como "estado em que a concentração de hemoglobina no sangue é anormalmente baixa em consequiência da carência de um ou mais nutrientes essenciais, qualquer que seja a origem desta carência" (OMS, 1968).

Entre as anemias nutricionais, a anemia por deficiência de ferro é a principal responsável pela elevada prevalência mundial (Freire, 1997). Geralmente resulta de ingestão insuficiente desse mineral, porém destacam-se também a baixa absorção e o 
aumento das perdas de ferro pelo organismo (Vannucchi et al., 1992; Szarfarc et al., 1995).

A reconhecida relevância desse tipo de anemia, em termos de saúde coletiva, decorre não apenas da magnitude de sua ocorrência atual, mas principalmente dos efeitos deletérios que ocasiona na saúde e na qualidade de vida.

As crianças constituem um dos grupos mais vulneráveis à anemia ferropriva, devido ao crescimento acelerado de todos os tecidos, impondo uma necessidade maior do mineral (Vannuchi et al., 1992; Lönnerdal \& Dewey, 1996). Segundo estimativas da OMS, $51 \%$ das crianças com menos de cinco anos e $46 \%$ daquelas com idade entre 5 e 12 anos dos países em desenvolvimento são anêmicas (DeMaeyer et al., 1989).

A carência de ferro na criança tem sido associada à diminuição da atividade motora e interação social, sonolência, irritabilidade, e incapacidade de fixar a atenção, que podem reduzir a capacidade de aprendizagem, e também comprometer o crescimento (DeMaeyer et al., 1989; Gillespie et al., 1991; Walter, 1996; WHO, 1996a). Quanto à associação entre deficiência de ferro, anemia e função imune, a revisão de Walter (1996) revela que ainda há muitas controvérsias sobre o assunto, uma vez que há tanto evidências de que a deficiência de ferro moderada pode promover a infecção, pois o déficit de ferro reduz a resposta imune, tornando o organismo mais susceptível às infecções, quanto uma leve deficiência de ferro pode proteger o organismo contra ela, uma vez que as bactérias necessitam de ferro para seu crescimento.

O diagnóstico clínico da anemia não constitui tarefa fácil, uma vez que estudos mostram que o tipo de anemia mais prevalente em nosso meio é a anemia leve (Monteiro et al., 2000b; Osório et al., 2001; Brunken et al., 2002; Assis et al., 2004a; 2004b; Ramos et al., 2004) e, portanto apresenta sinais e sintomas muito discretos, sendo na maioria dos casos assintomática (DeMaeyer et al., 1989). 
De modo geral, a identificação da anemia pode ser realizada por meio da observação de palidez em pele e mucosas. Sobre esse aspecto, vale destacar a estratégia da Atenção Integrada às Doenças Prevalentes na Infância (AIDPI), proposta pela OMS/UNICEF, com vistas a reduzir a mortalidade infantil a partir do controle de doenças mais prevalentes na infância (Ministério da Saúde, 1999). Nessa proposta, a identificação de uma palidez palmar fora do comum é sinal de anemia. Apesar de detectar apenas anemia moderada e grave, menos comum entre nós, essa estratégia chamou a atenção dos profissionais de saúde para a avaliação sistemática da anemia em todas as crianças atendidas, reforçando o diagnóstico precoce e o tratamento.

A dosagem de hemoglobina sanguínea é o método ideal e deve ser utilizada para um diagnóstico mais seguro. A OMS considera existência de anemia quando a concentração de hemoglobina é inferior a 11g/dL (OMS, 1968; DeMaeyer, 1989), podendo ser classificada em leve (10 a $11 \mathrm{~g} / \mathrm{dL})$, moderada ( 7 a $10 \mathrm{~g} / \mathrm{dL})$ e severa $(<7$ g/dL) (DeMaeyer et al., 1989).

A prevenção da anemia deve ser iniciada na gestação, durante o pré-natal, com a prescrição de suplemento medicamentoso, para se assegurar a adequada evolução do estado nutricional materno o qual garantirá a reserva adequada de ferro para o recémnascido (Gillespie et al., 1991).

Após o nascimento, o aleitamento materno exclusivo até os seis meses de idade assegura à criança, o ferro necessário para a manutenção das suas reservas orgânicas, entretanto, a partir daí, deve-se incluir alimentos que sejam boas fontes de ferro (Souza et al., 1997, Ministério da Saúde, 2002). Além disso, prevenir doenças infecciosas e promover campanhas educativas também são medidas eficazes no combate da anemia na população infantil. 


\section{Pressupostos e questões da pesquisa}




\section{PRESSUPOSTOS E QUESTÕES DA PESQUISA}

Tendo em vista a prevalência das deficiências nutricionais e sua repercussão nas taxas de morbi-mortalidade infantil, aliado à importância das creches como equipamentos sociais imprescindíveis para a promoção da saúde, delineou-se este estudo com a finalidade de caracterizar a saúde e a nutrição das crianças e levantar dados sobre conhecimentos e práticas de educadoras de uma creche para subsidiar propostas de intervenção com vistas a prevenir, detectar e controlar os problemas nutricionais mais comuns.

Teve como pressuposto, que a prevalência da desnutrição crônica (estatura/idade) seria superior a $10 \%$ e que a anemia nas formas leve e moderada estaria presente em mais de $40 \%$ das crianças estudadas, considerando-se que a prevalência da desnutrição e da anemia na década de 90, de acordo com estudos de Monteiro (2000a; $2000 b$ ) eram de, respectivamente, $10,5 \%$ e $46,9 \%$, e que a creche estudada localizava-se em região periférica da cidade de São Paulo, de grande exclusão social (Sposati, 1996).

Outro pressuposto foi que as educadoras teriam baixa escolaridade e qualificação profissional insuficiente (MEC, 1997; Barros et al., 1999), de forma que o conhecimento em relação aos sinais e sintomas, causas e consequiências dos distúrbios nutricionais seria deficiente e que as práticas não seriam adequadas e/ou seriam insuficientes para prevenir e/ou controlar as deficiências nutricionais estudadas, uma vez que mesmo sendo rotina encaminhar para a unidade de saúde mais próxima, todas as crianças com algum problema de saúde como febre, diarréia, vômito, varicela, escabiose, entre outros, não havia encaminhamento de crianças com déficits nutricionais (Boletim Mensal Creche, 2003 a 2004 - Anexo VIII).

Assim, conforme o exposto, as questões que nortearam este estudo foram: 
a) Será que a desnutrição e a anemia são mais freqüentes nessa creche, em relação à cidade de São Paulo, devido à exclusão social?

b) Será que as educadoras recebem treinamento para cuidar das crianças?

c) O que as educadoras consideram como problemas de saúde?

d) Será que as educadoras consideram os distúrbios nutricionais como problemas de saúde?

e) Será que as educadoras apresentam conhecimentos suficientes para reconhecer crianças desnutridas e anêmicas e práticas adequadas para prevenção e manejo das crianças com essas deficiências nutricionais? 
Objetivos 


\section{OBJETIVOS}

\subsection{Geral}

Identificar e analisar conhecimentos e práticas de educadoras de uma creche, relativas ao estado nutricional de crianças, com vistas a subsidiar propostas de intervenção para prevenir, detectar e controlar a desnutrição e a anemia a partir de ações intersetoriais.

\subsection{Específicos}

- Caracterizar as condições de vida, saúde e nutrição das crianças;

- Caracterizar as educadoras em relação à formação e experiência profissional;

- Identificar conhecimentos e práticas das educadoras em relação à desnutrição;

- Identificar conhecimentos e práticas das educadoras em relação à anemia. 
Metodologia 


\section{METODOLOGIA}

\subsection{Desenho da pesquisa}

Esta pesquisa de natureza transversal adota uma abordagem quantitativa e qualitativa para melhor compreensão do objeto de estudo e cumprimento dos objetivos propostos.

Do ponto de vista metodológico, segundo Minayo \& Sanches (1993), não há contradição na utilização concomitante dessas duas técnicas associadas, embora ambas tenham natureza diferente. As técnicas quantitativas têm como objetivo trazer à luz dados, indicadores e tendências observáveis, enquanto as qualitativas trabalham com valores, crenças, representações, hábitos, atitudes e opiniões, focalizando particularidades e especificidades dos grupos sociais estudados.

Sendo assim, a identificação e a descrição das características gerais das crianças e das educadoras foi abordada de forma quantitativa, enquanto a análise dos conhecimentos e práticas das educadoras o foi de modo qualitativo.

\subsection{Local de estudo}

O estudo foi desenvolvido em uma creche municipal conveniada, localizada no distrito de Lajeado, subprefeitura de Guaianases, zona leste da cidade de São Paulo.

A subprefeitura de Guaianases possui dois distritos, Guaianases com 8,60 $\mathrm{Km}^{2} \mathrm{e}$ 99.905 habitantes e Lajeado com 9,60 $\mathrm{Km}^{2}$ e 163.353 habitantes, num total de 263.258 habitantes (www.prefeitura.sp.gov.br).

O distrito do Lajeado faz divisa com os bairros de Itaim Paulista, Vila Curuçá, São Miguel Paulista, Itaquera, José Bonifácio e Guaianases (Mapa 1), e localiza-se na região mais excluída da cidade de São Paulo de acordo com o mapa da exclusão social elaborado por Sposati (1996). 
Mapa 1: Localização do distrito do Lajeado.

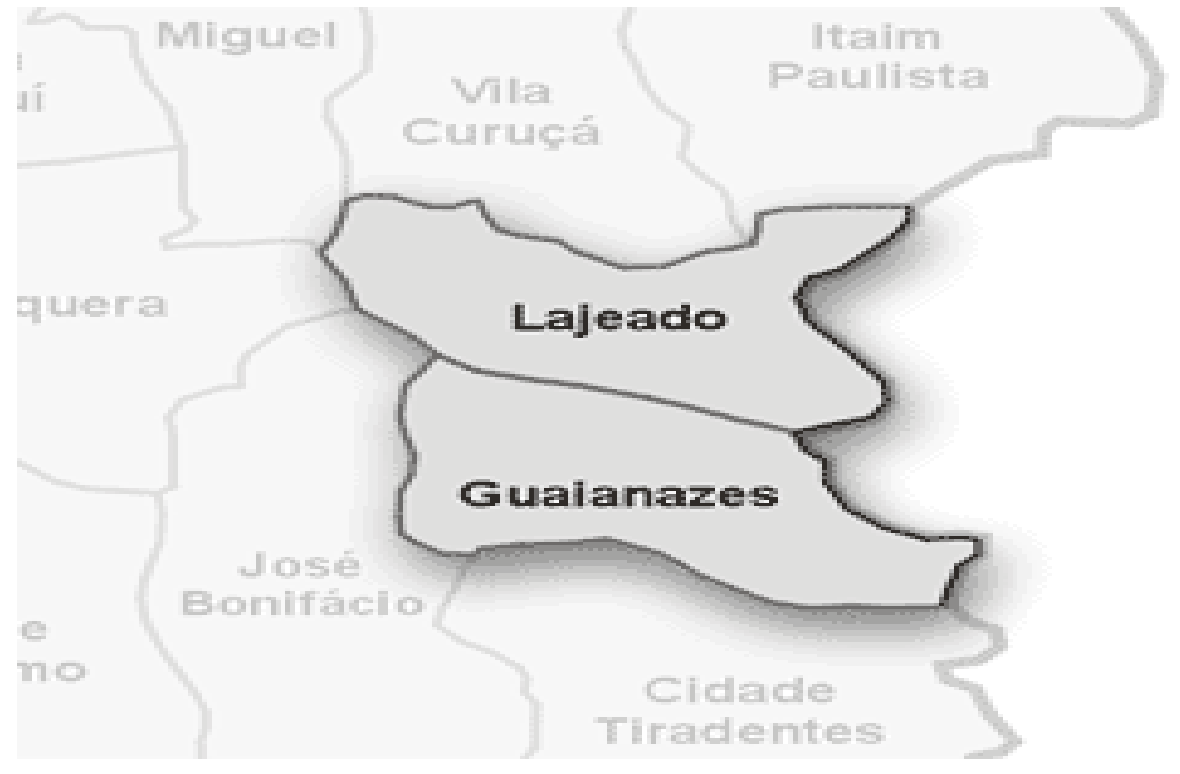

Fonte: www.prefeitura.sp.gov.br

O mapa da exclusão social, que foi construído para ser um instrumento de análise do processo de exclusão/inclusão social dos 96 distritos da cidade de São Paulo (Mapa 2), expressa as desigualdades sociais, econômicas, políticas e culturais, mostrando o distanciamento das condições de vida entre os distritos, por meio de índices que estabelecem notas de exclusão/inclusão social, a partir de padrões básicos de cidadania. A partir desse mapa, observa-se que a região de Guaianases localiza-se no extremo leste mais excluído da cidade de São Paulo, o que demonstra a precariedade das condições sócio-econômicas e ambientais da região, marcadas constantemente pelo desemprego, discriminação e violência.

Em 2002, a principal causa de morte na subprefeitura de Guaianases foi homicídio (204 óbitos), seguido pelas doenças isquêmicas do coração (157 óbitos), doenças cerebrovasculares (117 óbitos), pneumonias (81 óbitos) e diabetes mellitus (65 óbitos). Em relação às doenças de notificação compulsória, foram notificados 202 casos 
de tuberculose, 41 casos de AIDS e 6 casos de hanseníase (Secretaria Municipal de Saúde, 2003).

Mapa 2: Mapa da Exclusão Social da cidade de São Paulo.

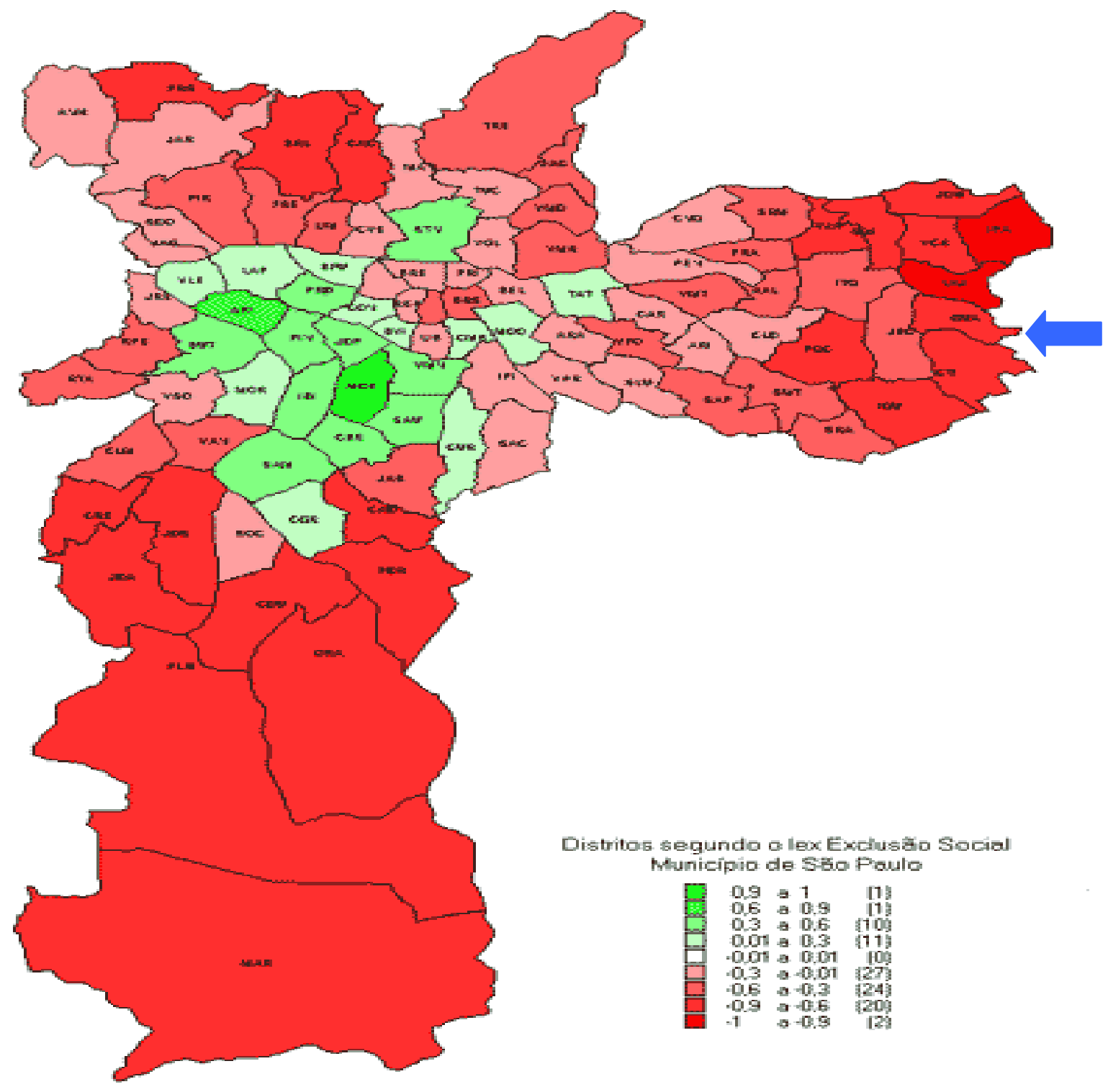

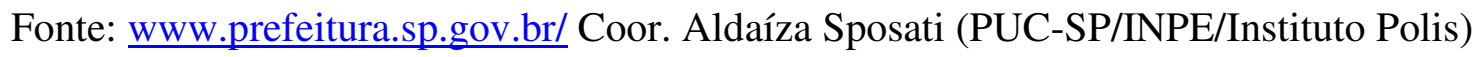

Do total de 5.530 nascidos vivos, $8,9 \%$ nasceram com baixo peso $(<2.500 \mathrm{~g})$, $18,8 \%$ eram de mães adolescentes $(<20$ anos) e 43,8\% de mães com menos de 7 consultas pré- natal. Em 2002, o coeficiente de mortalidade infantil foi de 16,9/1000 
nascidos vivos, com um total de 89 óbitos em crianças menores de 5 anos (Boletim CEInfo, 2003).

\section{$\underline{\text { A Creche }}$}

A Creche foi construída pela prefeitura em 1996, como resposta às lutas dos movimentos comunitários locais. Atualmente, está conveniada com a Pró-Saúde, que realiza o gerenciamento dos recursos financeiros provenientes da Prefeitura do Município de São Paulo.

Com capacidade para 170 crianças menores de 5 anos, é classificada como de grande porte. $\mathrm{O}$ horário de expediente é de segunda a sexta-feira, das 7 às $17 \mathrm{~h}$, sendo as atividades interrompidas apenas no mês de janeiro para período de férias coletivas dos funcionários e das crianças. O único critério para admissão da criança na creche é a idade.

A lista de espera é grande e a triagem para o preenchimento de vagas remanescentes durante o ano é realizada por entrevista com os pais e visitas domiciliárias às famílias. Nesses casos, há prioridade para mães que estão trabalhando no momento, crianças encaminhadas pelo serviço de saúde por apresentar risco nutricional ou desnutrição, e/ou crianças que apresentam risco social identificado durante a visita domiciliária por funcionário da creche.

O quadro de funcionários inclui 25 trabalhadores com carga horária de 40 horas semanais, sendo 1 diretora, 1 coordenadora, 1 auxiliar de enfermagem, 2 ajudantes de serviços gerais, 4 cozinheiras e 16 educadoras.

Quatro unidades de saúde do Programa de Saúde da Família, que atendem cerca de 4000 famílias cada (Santa Luzia, $1^{\circ}$ de Outubro, Jd. Indaiá e D. João Nery), localizam-se no entorno da creche, além de uma EMEI que atende 1080 crianças de 4 a 
6 anos, duas outras creches que atendem mais de 150 crianças cada uma e uma escola de ensino fundamental.

\subsection{População do estudo}

Das 170 crianças matriculadas na creche, o estudo envolveu 149 cujos pais ou responsáveis concordaram em participar da pesquisa, foram entrevistados e as crianças tiveram as medidas de peso e altura verificadas. Optou-se por estudar todo o universo de crianças, uma vez que a verificação das medidas antropométricas é um procedimento de rotina na creche.

Do total de 16 educadoras, que constituem o quadro de funcionários, apenas 1 , em licença maternidade, não participou do estudo.

Embora a designação oficial para trabalhadoras que cuidam de crianças em creche seja Auxiliar do Desenvolvimento Infantil (ADI), o termo "educadora" será adotado neste estudo, da mesma forma que Veríssimo et al. (2003a, 2003b), Melchiori et al. (2001), Farias e Padilha (2000), Maranhão (2000), Amaral et.al. (1996), Motta (1996), entre outros.

A distribuição das crianças por faixa etária e educadoras na época da coleta de dados é apresentada no Quadro 1:

Quadro 1. Distribuição das crianças por turma/ faixa etária, número de educadoras e relação educadora/criança.

\begin{tabular}{|ccccc|}
\hline Turma/Faixa etária & $\mathrm{N}^{\circ}$ de salas & $\mathrm{N}^{\circ}$ educadoras* & $\mathrm{N}^{\circ}$ de crianças & $\begin{array}{c}\text { Relação } \\
\text { educadora/criança }\end{array}$ \\
\hline A (menor de 1 ano) & 1 & 03 & 15 & $1: 3$ \\
B (1 a 2 anos) & 1 & 04 & 28 & $1: 7$ \\
C (2 a 3 anos) & 3 & 04 & 75 & $1: 18$ \\
D (3 a 5 anos) & 2 & 04 & 52 & $1: 13$ \\
\hline TOTAL & 7 & 15 & 170 & \\
\hline
\end{tabular}

*Uma educadora estava de licença maternidade 


\subsection{Coleta de dados}

A coleta de dados foi realizada na própria creche nos meses de junho, julho e agosto de 2004 por uma enfermeira (própria pesquisadora) e duas alunas de iniciação científica, graduandas da Escola de Enfermagem da USP, devidamente treinadas.

Para esclarecimento dos pais sobre o desenvolvimento da pesquisa, realizou-se uma reunião geral. A partir daí, as entrevistas foram realizadas no horário de entrada ou saída das crianças da creche, porém algumas entrevistas foram realizadas por telefone, e outras por meio de visitas domiciliárias, nos casos de pais que não foram encontrados na creche. Nas entrevistas, depois de tomada ciência e assinatura do Termo de Consentimento Livre e Esclarecido, os pais foram orientados a trazer o último exame de sangue da criança para avaliação do estado nutricional de ferro.

Para caracterizar as crianças, utilizou-se um formulário próprio, com dados obtidos a partir da ficha da criança na creche, e entrevista com os pais, para se obter informações a respeito da família e das crianças, tais como dados sócio-econômicos, condições maternas de gravidez e parto, e morbidade (Anexo 1). As crianças foram pesadas e medidas e tiveram avaliação da palidez palmar. Nenhuma criança apresentou patologias que interferissem no estado nutricional e/ou impossibilitassem a verificação das medidas antropométricas, como uso de aparelhos ortopédicos ou deformidades corporais.

Tendo em vista que os dados relacionados às educadoras envolviam dados subjetivos, relativos às atitudes, crenças e opiniões das entrevistadas, esta etapa da coleta de dados foi realizada pela própria pesquisadora, por meio de entrevista individual, realizada em uma sala reservada na creche, seguindo-se os cuidados recomendados por Chizzotti (2001), ou seja, ouvir atentamente as informações prestadas, intervir com discretas interrogações de conteúdo ou com sugestões que 
estimulem a expressão mais circunstanciada de questões que interessem à pesquisa, de forma a manter um diálogo descontraído que deixasse a educadora livre para exprimirse, sem constrangimentos sobre seus atos ou idéias.

Utilizou-se um instrumento composto por duas partes, uma com dados de identificação pessoal e outra parte com um roteiro semi-estruturado relativo aos conhecimentos e práticas das educadoras sobre desnutrição e anemia (Anexo II). As entrevistas tiveram duração média de 30 minutos, foram gravadas e posteriormente, transcritas na íntegra.

\subsection{Avaliação do estado nutricional}

Desnutrição

O peso e estatura/comprimento das crianças foram verificados utilizando-se técnicas padronizadas pelo Ministério da Saúde (2001).

As crianças dos grupos A (0 a 1 ano) e B ( 1 a 2 anos) foram pesadas e medidas no momento do banho, antes ou depois, aproveitando-se que elas estavam totalmente despidas. Para a verificação do comprimento dessas crianças, utilizou-se uma régua antropométrica de madeira (sem marca) com precisão de 0,1 centímetro, com as crianças deitadas. A aferição do peso foi feita em balança pediátrica mecânica com prato acoplado e capacidade para $15 \mathrm{~kg}$, com precisão de 10 gramas (marca Baxter).

Crianças maiores, dos grupos C (2 a 3 anos) e D (3 a 4 anos), foram pesadas e medidas na sala de enfermagem, somente com roupas íntimas e descalças. A estatura foi aferida utilizando-se o antropômetro acoplado à balança de adulto com precisão de 0,1 centímetro e o peso foi verificado no mesmo equipamento com capacidade para $150 \mathrm{~kg}$ e precisão de $100 \mathrm{~g}$ (marca Welmy). 


\section{Anemia}

A verificação da palidez palmar é uma proposta da OMS/UNICEF na estratégia AIDPI (Atenção Integrada as Doenças Prevalentes na Infância) para detectar anemia em crianças menores de cinco anos a partir de sinais clínicos simples (Brasil, 1999). Embora alguns estudos demonstrem uma baixa concordância e sensibilidade dessa técnica em relação ao diagnóstico da anemia (Spinelli et al., 2003; Ramos et al., 2004), ela foi utilizada nesse estudo, como um método alternativo para triagem da anemia, uma vez que não foi objetivo desse estudo estimar a prevalência de anemia na creche.

Esse procedimento foi realizado somente pela própria pesquisadora, devidamente capacitada na estratégia AIDPI. As crianças que apresentaram palidez palmar foram encaminhadas ao serviço de saúde local para as devidas providências.

\subsection{Procedimentos ético-legais}

Os procedimentos adotados atenderam ao rigor científico e aos aspectos éticos da pesquisa envolvendo seres humanos, como descritos a seguir:

Ética e Pesquisa: o projeto foi submetido ao Comitê de Ética em Pesquisa da Escola de Enfermagem da USP e foi solicitada autorização à direção da creche para a realização do estudo no local (Anexo III).

Direitos Humanos: como medida de proteção aos direitos humanos, antes da coleta de dados, as mães e/ou responsáveis pelas crianças e as educadoras foram informadas detalhadamente sobre os objetivos da pesquisa, a coleta de dados e os encaminhamentos quando se fizerem necessários. A liberdade de se recusar a participar ou retirar seu consentimento, em qualquer fase da pesquisa foi assegurada aos sujeitos sem penalização alguma ou prejuízo ao seu cuidado. Também foram garantidos o sigilo das informações colhidas e a privacidade dos sujeitos. A coleta de dados foi realizada 
somente depois de tomada ciência e assinatura do Termo de Consentimento Livre e Esclarecido, em duas vias, uma retida pelo sujeito da pesquisa e/ou seu responsável, e outra arquivada pelo pesquisador (Anexo IV e V).

Encaminhamentos: a classificação do estado nutricional das crianças foi fornecida por escrito para cada mãe ou responsável, com explicação de seu significado (Anexo VI) e as crianças com resultados alterados foram encaminhadas ao serviço de saúde local (Anexo VII). Todos os dados foram encaminhados à equipe de saúde local, para que se possa avaliar a prestação dos serviços de saúde específicos a essa população e subsidiar o planejamento de intervenções que possibilitem diminuir a prevalência da anemia e da DEP na população estudada.

\subsection{Sistematização e análise dos dados}

Para análise dos dados relativos à caracterização das crianças e educadoras, procedeu-se uma análise quantitativa: os dados pré-codificados foram organizados em bancos do software Excel e analisados utilizando-se o software EpiInfo 6.

Para caracterizar o estado nutricional das crianças, utilizou-se o software EpiNut, acoplado ao EpiInfo 6, que gerou valores individuais de escore $\mathrm{Z}$ dos índices peso para idade $(\mathrm{P} / \mathrm{I})$, altura para idade $(\mathrm{A} / \mathrm{I})$ e peso para altura $(\mathrm{P} / \mathrm{A})$, tendo como referência o padrão

Norte-Americano do National Center for Health Statistics (NCHS). Os índices antropométricos foram categorizados de acordo com os seguintes intervalos de escore $\mathrm{Z}$ : menor que -2 (déficit nutricional), de -2 a -1 (risco nutricional), entre -1 e +1 (eutrofia), de +1 a +2 (risco de sobrepeso) e maior que +2 (sobrepeso), da mesma forma que Bueno et al. (2003). 
Os dados relativos à caracterização dos conhecimentos e práticas das educadoras sobre desnutrição e anemia foram submetidos a uma análise qualitativa, utilizando-se a técnica "análise de conteúdo" proposta por Bardin (1979). Para tanto as entrevistas foram gravadas e transcritas na íntegra.

Segundo Minayo (1998), essa técnica é a mais comumente utilizada para o tratamento dos dados de uma pesquisa qualitativa no campo das investigações sociais.

A análise de conteúdo pode ser definida como:

"Um conjunto de técnicas de análise de comunicação visando obter, por procedimentos sistemáticos $e$ objetivos de descrição de conteúdo das mensagens, indicadores (quantitativos ou não) que permitam a inferência de conhecimentos relativos às condições de produção/recepção destas mensagens”. (Bardin, 1979, 42).

Dentre o conjunto de técnicas contempladas pela análise de conteúdo proposto por Bardin (1979), tais como análise da enunciação, análise da expressão, análise das relações, entre outras, este estudo desenvolveu a análise temática.

A análise temática consiste na identificação dos núcleos de sentido ou temas que compõe a comunicação, cuja frequiência ou presença tenham um significado para o objetivo da pesquisa e tanto pode assumir um caráter quantitativo, quando se encaminha para a contagem das frequiências dos temas, como pode ser qualitativo quando avalia os valores de referência dos temas (Minayo, 1998).

Para análise temática, procedeu-se inicialmente à leitura integral e exaustiva dos discursos na tentativa de apreender seu sentido global. Na seqüência, cada discurso foi submetido a uma "dissecação", visando-se extrair as frases temáticas a partir das falas das educadoras e de acordo com as questões norteadoras. O material resultante foi organizado em quadros que apresentam as questões norteadoras sobre os conhecimentos e práticas das educadoras sobre desnutrição e anemia com seus respectivos temas. 
Resultados e discussão 


\section{APRESENTAÇÃO E DISCUSSÃO DOS RESULTADOS}

\subsection{Caracterização dos sujeitos da pesquisa}

O conhecimento das características gerais de uma dada população deve constituir a primeira etapa a ser considerada para compreensão do objeto de estudo. Características físicas, sócio-econômicas e demográficas revelam as condições de vida e de saúde de um determinado grupo populacional. Assim, neste estudo, dois grupos distintos foram caracterizados: as crianças e as educadoras. A caracterização das crianças foi realizada apenas no sentido de melhor contextualizar os conhecimentos e as práticas das educadoras.

\subsubsection{Caracterização das crianças}

A Tabela 1 apresenta características gerais das crianças estudadas. Observou-se uma proporção ligeiramente maior de crianças do sexo masculino $(54,8 \%)$ e na faixa etária de 36 a 48 meses (30,1\%), seguida pelo grupo de 24 a 36 meses (22,6\%). O trabalho materno foi apontado por $86,3 \%$ dos entrevistados como o principal motivo para o ingresso da criança na creche. Embora o trabalho materno não seja utilizado como critério para priorizar a matrícula da criança na creche, esse acaba sendo um dos motivos para desempate, caso as crianças tenham a mesma data de inscrição. Não houve nenhuma referência quanto ao ingresso na creche por risco nutricional.

Quanto ao tempo de freqüência, a maioria das crianças $(86,5 \%)$ freqüentava a creche há mais de 6 meses. A grande maioria das crianças $(78,7 \%)$ pertencia a famílias constituídas por 4 ou mais pessoas, com renda per capita inferior a 0,5 salário mínimo $(64 \%)$. 
Tabela 1. Distribuição das crianças segundo variáveis sócio-econômicas-demográficas e de saúde.

\begin{tabular}{|c|c|c|}
\hline Variáveis & $\mathbf{n}$ & $\%$ \\
\hline \multicolumn{3}{|l|}{ Sexo } \\
\hline Masculino & 80 & 54,8 \\
\hline Feminino & 66 & 45,2 \\
\hline \multicolumn{3}{|l|}{ Faixa etária } \\
\hline 0 a 6 meses & 01 & 0,7 \\
\hline 6 a 12 meses & 12 & 8,2 \\
\hline 12 a 24 meses & 28 & 19,2 \\
\hline 24 a 36 meses & 33 & 22,6 \\
\hline 36 a 48 meses & 44 & 30,1 \\
\hline 48 meses e mais & 28 & 19,2 \\
\hline \multicolumn{3}{|c|}{ Motivo de ingresso na creche (referido por familiares) } \\
\hline Trabalho materno & 126 & 86,3 \\
\hline Baixas condições sócio-econômicas & 6 & 4,1 \\
\hline Outros & 14 & 9,6 \\
\hline \multicolumn{3}{|l|}{ Tempo de freqüência à creche* } \\
\hline$<6$ meses & 19 & 13,6 \\
\hline$\geq 6$ meses & 121 & 86,4 \\
\hline \multicolumn{3}{|c|}{ Número de pessoas na mesma residência da criança } \\
\hline$<4$ & 31 & 21,2 \\
\hline$\geq 4$ & 115 & 78,8 \\
\hline \multicolumn{3}{|c|}{ Renda familiar ( salário mínimo per capita)* } \\
\hline $0-0,5$ & 89 & 64,0 \\
\hline $0,5-1,0$ & 39 & 28,1 \\
\hline$\geq 1$ & 11 & 7,9 \\
\hline \multicolumn{3}{|l|}{ Pré-natal* } \\
\hline Sim & 141 & 97,9 \\
\hline Não & 3 & 2,1 \\
\hline \multicolumn{3}{|l|}{ Duração da gravidez } \\
\hline$<9$ meses & 25 & 17,1 \\
\hline$\geq 9$ meses & 121 & 82,9 \\
\hline \multicolumn{3}{|l|}{ Peso ao nascer } \\
\hline$<2.500 \mathrm{~g}$ & 09 & 6,2 \\
\hline$\geq 2.500 \mathrm{~g}$ & 137 & 93,8 \\
\hline \multicolumn{3}{|l|}{ Aleitamento materno* } \\
\hline $\mathrm{Sim}$ & 127 & 88,2 \\
\hline Não & 17 & 11,8 \\
\hline \multicolumn{3}{|l|}{ Duração do aleitamento (em meses)* } \\
\hline$<3$ meses & 24 & 22,9 \\
\hline 3 a 6 meses & 25 & 23,8 \\
\hline$\geq 6$ meses & 56 & 53,3 \\
\hline \multicolumn{3}{|l|}{ Freqüência a posto de saúde } \\
\hline Sim & 124 & 84,9 \\
\hline Não & 22 & 15,1 \\
\hline \multicolumn{3}{|l|}{ Carteira de vacinação atualizada* } \\
\hline Sim & 140 & 99,3 \\
\hline Não & 1 & 0,7 \\
\hline \multicolumn{3}{|l|}{ Uso de medicação* } \\
\hline Sim & 62 & 42,8 \\
\hline Não & 83 & 57,2 \\
\hline \multicolumn{3}{|l|}{ Principais medicamentos utilizados $* *$} \\
\hline Suplementação vitamínica & 48 & 64,9 \\
\hline Sulfato ferroso & 14 & 18,9 \\
\hline Antibióticos & 12 & 16,2 \\
\hline
\end{tabular}

* Não foram obtidas informações para a totalidade das crianças.

** Mais de um medicamento foi referido para a mesma criança. 
A renda per capita é uma das medidas mais comumente utilizadas para se verificar o padrão de vida de uma população. As pessoas são consideradas pobres se o seu consumo ou renda for inferior a um certo limite necessário para satisfazer suas necessidades básicas. Esse limite mínimo é denominado "linha da pobreza". O Banco Mundial utiliza como linha de referência para medir a pobreza de uma população, a renda per capita de um ou dois dólares por dia (Moreira, 1999). Tomando-se então essa referência para análise do nível de pobreza desse grupo, pode-se dizer que a maioria das famílias (64\%) encontrava-se abaixo da linha de pobreza, ou seja, não possuía as condições mínimas para satisfazer suas necessidades básicas.

Quanto ao peso das crianças ao nascer, constatou-se que apenas 6,1\% das crianças nasceram com baixo peso $(<2.500 \mathrm{~g})$. Considerando a procedência, região de forte exclusão social, talvez o acesso aos serviços de saúde (84,9\% das famílias eram cadastradas em alguma unidade de saúde, 96,6\% das mães tiveram acesso ao pré-natal e $82,9 \%$ das crianças nasceram a termo, ou seja, com nove meses de gestação ou mais) possa justificar esse achado, uma vez que os dados da Pesquisa Nacional sobre Saúde e Nutrição (Monteiro, 1992), mostraram uma incidência estável, em torno de 10\%, desse indicador no país.

Quanto ao aleitamento materno, 86,9\% $(\mathrm{n}=127)$ das crianças foram amamentadas, porém apenas $38,3 \%$ receberam leite materno por um período igual ou superior a 6 meses.

O uso de algum tipo de medicação no momento da entrevista foi referido para 42,8\% (n=62) das crianças, sendo que a grande maioria fazia uso de suplementação vitamínica ou mineral, porém 16,2\% estavam usando antibióticos. 
Os dados relativos à morbidade são apresentados na Tabela 2. Constatou-se que $60,3 \%$ das crianças adoeceram nos últimos 15 dias que antecederam a entrevista. A febre foi referida por $22,7 \%$ dos entrevistados. Os sintomas relacionados aos problemas do trato respiratório foram responsáveis por $79,6 \%$ das queixas, enquanto os gastrointestinais representaram $20,5 \%$ dos principais sintomas referidos.

Tabela 2. Distribuição das crianças segundo presença de doença e sintomas referidos nos quinze dias anteriores à entrevista.

\begin{tabular}{lrr}
\hline \multicolumn{1}{c}{ Doenças e sintomas } & n & \% \\
\hline $\begin{array}{l}\text { Adoecimento nos últimos 15 dias } \\
\text { Não }\end{array}$ & 58 & 39,7 \\
Sim \\
Sintomas* \\
$\quad$ Febre & 88 & 60,3 \\
Do aparelho respiratório & 20 & 22,7 \\
Tosse & 18 & 20,4 \\
Gripe & 17 & 19,3 \\
Bronquite & 11 & 12,5 \\
Resfriado/ garganta inflamada & 10 & 11,4 \\
Coriza & 06 & 6,8 \\
Pneumonia/ broncopneumonia/ otite & 05 & 5,7 \\
Sinusite/ peito cheio & 03 & 3,4 \\
Do aparelho gastrintestinal & & \\
Diarréia & 08 & 9,1 \\
Vômito & 07 & 8,0 \\
Inapetência/ dor de barriga/ verme & 03 & 3,4 \\
\hline Outros** & 06 & 6,8 \\
\hline * Para cada criança foi referido mais de um sintoma. & &
\end{tabular}

Benício et al. (1992), analisando os dados da Pesquisa Nacional sobre Saúde e Nutrição, encontraram resultados similares em relação à febre $(21,8 \%)$ e aos sintomas do aparelho gastro-intestinal $(29,2 \%)$, porém, os sintomas do aparelho respiratório, de um modo geral, constituíram apenas $24 \%$ das queixas referidas. Acredita-se que essa discrepância em relação aos problemas respiratórios reitera os estudos sobre a saúde das crianças que freqüentam creches, onde os problemas respiratórios se destacam como os de maior prevalência (Fuchs et al., 1996; Amaral et al., 1997; Fonseca et al., 1997; Barros, 1999; Prado et al., 2002). 
Fonseca et al. (1997), analisando fatores de risco para pneumonia em menores de dois anos na região metropolitana de Fortaleza, $\mathrm{CE}$, apontaram a freqüência à creche como um dos fatores de risco de maior magnitude para a incidência das infecções respiratórias. Revisão da literatura sobre a freqüência em creches e sua associação com infecções respiratórias e diarréia, revela que apesar das diferenças de medidas e resultados desiguais, os estudos se mostraram consistentes no sentido de associar a freqüência à creche com um maior risco da incidência dessas morbidades (Barros, 1999).

Quanto ao estado nutricional, constatou-se, surpreendentemente, um número insignificante de desnutrição, como pode ser observado na Tabela 3:

Tabela 3. Distribuição das crianças quanto ao estado nutricional caracterizado segundo escore $\mathrm{Z}$ de peso/idade, peso/altura e altura/idade.

\begin{tabular}{lcccccc}
\hline \multirow{2}{*}{ Índices } & \multicolumn{2}{c}{ Peso/Idade } & \multicolumn{2}{c}{ Altura/Idade } & \multicolumn{2}{c}{ Peso/Altura } \\
\cline { 2 - 7 } & $\mathbf{n}$ & $\mathbf{\%}$ & $\mathbf{n}$ & $\mathbf{\%}$ & $\mathbf{n}$ & $\mathbf{\%}$ \\
\hline $\mathrm{Z}<-2$ & 04 & 2,7 & 03 & 2,0 & 01 & 0,7 \\
$-2 \leq \mathrm{Z}<-1$ & 21 & 14,0 & 20 & 13,4 & 12 & 8,1 \\
$-1 \leq \mathrm{Z}<+1$ & 101 & 67,8 & 103 & 69,1 & 108 & 72,5 \\
$+1 \leq \mathrm{Z}<+2$ & 22 & 14,8 & 21 & 14,2 & 24 & 16,0 \\
$\mathrm{Z} \geq+2$ & 01 & 0,7 & 02 & 1,3 & 04 & 2,7 \\
Total & $\mathbf{1 4 9}$ & $\mathbf{1 0 0}$ & $\mathbf{1 4 9}$ & $\mathbf{1 0 0}$ & $\mathbf{1 4 9}$ & $\mathbf{1 0 0}$ \\
\hline
\end{tabular}

Em função da creche estudada estar localizada em região de forte exclusão social, esperava-se que a prevalência da desnutrição fosse maior do que a encontrada, uma vez que estudos demonstram uma prevalência em torno de 5 a $21 \%$ de desnutrição em crianças que freqüentam creches (Antonio et al., 1996; Siviero et al., 1997; Silva et al., 1998; Taddei et al., 2000; Bueno et al., 2003).

Acredita-se que alguns fatores possam ter contribuído para esse resultado. Um deles é o fato das crianças passarem a maior parte do tempo na creche e por isso terem acesso a uma alimentação de boa qualidade. Alguns estudos mostram que há uma 
relação entre frequiência à creche e melhora do estado nutricional, ou seja, as creches são apontadas como um fator de proteção contra a desnutrição (Silva et al., 1998; Silva et al., 2000; Taddei et al., 2000; Correa et al., 1999; Brunken et al., 2002; Correa et al., 2002; Bueno et al., 2003).

Os resultados da pesquisa de Silva \& Sturion (1998), que analisaram o estado nutricional de 2096 pré-escolares atendidos em 27 Centros Educacionais de Piracicaba, SP, mostraram a influência estatisticamente significante exercida pelo tempo de permanência em creches sobre o escore $\mathrm{Z}$ de altura para idade das crianças.

Bueno et al. (2003), investigando o crescimento de crianças atendidas em creches públicas do município de São Paulo, SP, também constataram que a creche apresenta impacto positivo sobre o estado nutricional das crianças ao final do primeiro ano.

Da mesma forma como comentado para o baixo peso ao nascer, o acesso aos serviços de saúde na região pode ter contribuído para a baixa prevalência da desnutrição na creche em estudo, pois como demonstrado por Monteiro et al. (1992), o acesso da população a serviços essenciais como os de saúde, educação e saneamento, é capaz de modular o efeito da renda sobre os determinantes do estado nutricional das crianças.

O estado nutricional de ferro das crianças foi analisado sob três aspectos: episódio anterior de anemia referida nas entrevistas pelos responsáveis; níveis de hemoglobina em exame recente (últimos 6 meses); e avaliação da palidez palmar. A Tabela 4 apresenta essas informações. 
Tabela 4. Distribuição das crianças segundo dados sobre estado nutricional de ferro.

\begin{tabular}{lcc}
\hline Variáveis & $\mathbf{n}$ & $\mathbf{\%}$ \\
\hline Presença de anemia em algum momento da vida & & \\
Sim & 52 & 35,6 \\
Não & 85 & 58,2 \\
Não sabe & 09 & 6,2 \\
Idade em que teve anemia (em meses)* & & \\
$0 \vdash 6$ & 08 & 15,7 \\
$6 \vdash 9$ & 08 & 15,7 \\
$12 \vdash 18$ & 21 & 41,2 \\
$\geq 18$ & 14 & 27,4 \\
Forma pela qual descobriu a anemia* & & \\
Avaliação laboratorial & 44 & 88,0 \\
Avaliação clínica & 06 & 12,0 \\
Níveis de hemoglobina (g/dL) de exame recente & & \\
$\quad<9$ & 01 & 3,3 \\
9 a 10 & 06 & 20,0 \\
10 a 11 & 06 & 20,0 \\
$\geq 11$ & 17 & 56,7 \\
Palidez Palmar & & \\
Sim & 10 & 6,8 \\
Não & 136 & 93,2 \\
\hline
\end{tabular}

* Não foram obtidas informações para a totalidade das crianças.

A entrevista com os responsáveis revelou que 35,6\% das crianças já haviam tido anemia em algum momento da vida. Dessas, $84,3 \%$ tiveram com idade superior a 6 meses e $88 \%$ dos casos foram identificados por meio de exame laboratorial.

A avaliação dos níveis de hemoglobina pôde ser realizada em 30 crianças que apresentaram exame recente. Os exames apontaram 43,3\% das crianças com níveis de hemoglobina abaixo de $11 \mathrm{~g} / \mathrm{dL}$. Vale destacar que houve apenas 1 criança com hemoglobina abaixo de $9 \mathrm{~g} / \mathrm{dL}$, portanto, quase a totalidade das crianças havia apresentado anemia leve.

Diversos estudos também apontam prevalência de anemia acima de $30 \%$ entre crianças que freqüentam creches (Guerra et al., 1986; Brunkem et al., 2002; Oliveira et al., 2002; Silva et al., 2001; Assis et al., 2004b), da mesma forma como observado nesse estudo. Há que se destacar, no entanto, a possibilidade de se tratar de uma amostra viciada, uma vez que muito provavelmente os exames tenham sido realizados por 
alguma suspeita clínica do profissional ao examinar a criança ou queixa prévia dos pais ao procurarem o serviço de saúde.

A palidez palmar foi identificada em apenas 10 crianças, sendo que somente 5 delas haviam realizado exame recente, permitindo-se comprovar o diagnóstico clínico com dados laboratoriais. Houve comprovação da anemia em $60 \%$ dos casos, ou seja, 3 crianças com palidez palmar também apresentavam níveis de hemoglobina inferiores a $11 \mathrm{~g} / \mathrm{dL}$.

Alguns estudos realizados na África em crianças com idade inferior a 5 anos apontam os sinais clínicos de palidez palmar, de conjuntivas e de leito ungueal como instrumentos importantes na detecção da anemia (Luby et al., 1995; Weber et al., 1997; Zucker et al., 1997), de forma que na estratégia AIDPI, a palidez palmar foi incorporada para avaliar anemia.

No Brasil, entretanto, Ramos et al. (2004) constataram que esse marcador não foi útil para detectar a presença de anemia entre as 242 crianças estudadas no município de Itupeva, SP, uma vez que a grande maioria das crianças apresentavam anemia leve, com níveis de $\mathrm{Hb} \geq 9,0 \mathrm{~g} / \mathrm{dL}$.

Entretanto, os resultados aqui obtidos demonstram que a anemia é o distúrbio nutricional mais prevalente entre as crianças da creche estudada.

\subsubsection{Caracterização das educadoras}

As 16 educadoras representam 64\% do quadro de funcionários da creche e são responsáveis pelos cuidados direto com a criança, tais como higiene, alimentação e repouso, além das atividades de recreação e educação propriamente dita. Fizeram parte 
deste estudo 15 educadoras (94\%), pois uma se encontrava em licença maternidade. O Quadro 2 sumariza as informações a respeito das educadoras.

O fato dessa categoria ser composta somente por mulheres confirma a tendência geral e histórica de que o trabalho de cuidado e educação da criança ainda constitui uma tarefa essencialmente feminina (Rosemberg, 1999). Dados do MEC (1997) revelam que 85,6\% dos professores da educação básica no Brasil são do sexo feminino.

Com relação à idade, observa-se que há uma concentração na faixa etária de 21 a 29 anos $(\mathrm{n}=10)$, com média e mediana de 28 anos.

A maioria das educadoras $(n=9)$ reside em Guaianases, ou seja, na mesma região de localização da creche e de moradia das crianças, enquanto as outras residem nas imediações. Trata-se, portanto, de um grupo homogêneo, do ponto de vista social, isto é, tanto educadoras como crianças estão inseridas numa região com as mesmas condições sociais, econômicas e culturais.

A grande maioria possui filhos na faixa etária de 3 meses a 9 anos, com média e mediana de 5 anos.

Todas as educadoras referiram ter concluído o segundo grau, sendo que oito haviam feito magistério, resultado similar ao encontrado por Shibayama (2001), Veríssimo (2001) e Carmo (2004), que estudaram creches no município de São Paulo, SP. 
QUADRO 2 
Segundo dados do MEC (1997), no Brasil 14,9\% dos educadores de pré-escola não possuem o primeiro grau completo, $58,1 \%$ completaram o segundo grau e $26,6 \%$ têm nível superior ou mais. Entretanto, há grandes desigualdades regionais: no Nordeste $32,7 \%$ dos educadores não possuem o primeiro grau completo, enquanto na região Sudeste essa proporção é de apenas $0,8 \%$.

A Lei de Diretrizes e Bases (LDB), no seu artigo 62, estabelece que o professor de educação infantil deve ser formado em curso de nível superior (licenciatura de graduação plena), admitida, porém, como formação mínima, aquela oferecida em nível médio, na modalidade normal (Brasil, 1996), realidade encontrada na creche estudada.

A maioria das educadoras trabalha na creche há pelo menos 4 anos $(60 \%)$ e somente uma delas referiu experiência anterior. Entretanto, apenas cinco educadoras (33\%) haviam recebido treinamento específico para o ingresso na creche. A maioria $(66,6 \%)$ não recebeu nenhum tipo de treinamento inicial para o trabalho, contando apenas com a experiência anterior de cuidar de crianças da família, pois a maioria já cuidava dos filhos e sobrinhos $(n=13)$ e apenas duas educadoras nunca tinham cuidado de crianças.

Há que se considerar que apenas a experiência anterior de cuidar de crianças num ambiente doméstico é insuficiente para a compreensão dos objetivos propostos pela Educação Infantil - desenvolvimento integral da criança de 0 a 6 anos, em seu aspecto físico, psicológico, intelectual e social, complementando a ação da família e da comunidade (Brasil, 1996) - que exige formação e especialização regulares, bem como mecanismos de atualização dos profissionais.

Segundo Haddad (1991), as políticas fundamentadas em concepções compensatórias geralmente propõem mão de obra barata que explora o trabalho de mulheres de baixa escolaridade, supondo que por meio de suas habilidades naturais elas 
possam realizar a prática educacional com crianças pequenas, mesmo na ausência de formação prévia.

O Conselho Nacional de Credenciamento de Creches da Austrália (1993) coloca como um dos princípios de qualidade da creche, a oferta de treinamento regular da equipe para ajudar a desenvolver habilidades relacionadas ao trabalho com a criança e a família.

Assim, vale destacar que além da formação mínima exigida, a qualidade dos serviços prestados pelos educadores infantis depende de um treinamento contínuo para que tenham oportunidade de atualizar seus conhecimentos, compartilhar suas habilidades, trocar experiências e assim, melhorar os cuidados prestados à criança.

\subsection{Principais problemas de saúde na creche}

Para Bittencourt \& Magalhães (1999), os profissionais de saúde dificilmente reconhecem a desnutrição como um problema de saúde, ou seja, não encaram os distúrbios nutricionais como uma doença, especialmente por considerá-la um problema social. Assim, iniciou-se a entrevista com a seguinte questão: Qual o principal problema de saúde das crianças aqui da creche? Essa questão visou avaliar se para as educadoras, os distúrbios nutricionais constituem ou não um problema de saúde.

Para a maioria das educadoras, os principais problemas de saúde referem-se a problemas respiratórios e gastrointestinais, como ilustram as falas abaixo:

"Diarréia, resfriado que nunca vai embora, e nariz escorrendo com catarro verde que a gente tenta, mas num tem jeito, é sempre a diarréia e o resfriado que são os principais (...)".

"É gripe, pneumonia e diarréia, é o mais comum, acho que é porque vive muita criança numa sala, dai eles ficam assim". 
Esses depoimentos, em síntese, revelam que os problemas respiratórios e gastrointestinais são muito representativos para as educadoras, isso possivelmente devido à sua elevada freqüência entre as crianças estudadas (Tabela 2).

Realmente, como já destacado, outros estudos realizados em creche apontam as doenças respiratórias como a primeira causa de adoecimento, seguida das doenças diarréicas (Amaral et al., 1997; Fonseca et al., 1997; Prado et al., 2002).

Amaral et al. (1997), em estudo realizado no sul do país, mostraram que crianças freqüentadoras de creche apresentavam risco 2,4 vezes maior de adoecer por infecções respiratórias se comparadas àquelas que não freqüentavam creches. Resultados similares foram encontrados num estudo caso-controle realizado em Fortaleza, CE, demonstrando que crianças freqüentadoras de creches estavam 5 vezes mais expostas ao risco de contrair pneumonia em relação às que não freqüentavam creches (Fonseca et al., 1997).

A forte prevalência desses agravos entre as crianças freqüentadoras de creche pode estar associada a diversos fatores. Um deles refere-se ao fato das crianças menores de 5 anos encontrarem-se num período da vida de grande vulnerabilidade às infecções. Outro ponto a se destacar refere-se aos ambientes coletivos, como o da creche, que contribuem para a propagação de doenças e reinfecções constantes, principalmente infecções respiratórias e diarréia (Fuchs et al., 1996; Barros, 1999).

Há que se destacar que os problemas nutricionais também foram citados como problemas de saúde pelas educadoras, mesmo que em menor escala. Sobre esse aspecto, observa-se que prevaleceram os problemas relacionados à aceitação da alimentação pela criança, de forma que ao falar das doenças, lembram-se logo da falta de apetite que as crianças apresentam durante esse período. Com relação à desnutrição e à anemia, apenas 2 educadoras apontaram como sendo um problema comum entre as crianças da creche, 
que talvez só tenha sido lembrado devido ao conhecimento que tinham do tema da pesquisa.

“(...) o nariz não pára de escorrer nunca, [daí] as crianças não aceitam muito a alimentação, dão o maior trabalho pra comer (...)".

"Ah, quando eles estão abatidos, ou ânsia de vômito, que é mais comum, [daí] eles não comem".

“Anemia tem bastante aqui (...)".

"Aqui é a desnutrição. Apesar de que esse ano não tem, o ano passado até teve. Esse ano está bem methor. $\mathcal{N} a ̃ o$ tem nenhuma criança que você olhe e diga que está desnutrida".

As infecções agudas são comumente acompanhadas por perda do apetite e, conseqüentemente, perda temporária de peso, que pode ser restabelecido quando se resolve o processo inflamatório (Farthing, 2001). Entretanto, nem sempre a criança consegue recuperar-se, ingressando no ciclo: "infecção - perda de peso - desnutrição", com maior chance de adoecer e morrer, como já revelado na década de 70, por Puffer \& Serrano (1973), cujos resultados mostraram que a deficiência nutricional era causa associada em $60,9 \%$ das mortes por doenças infecciosas.

As infecções gastrointestinais também contribuem para o desenvolvimento da desnutrição infantil, especialmente porque prejudica a absorção intestinal dos nutrientes. Segundo Brown (2001), as infecções gastrointestinais têm maior probabilidade de ocorrer em crianças com déficit nutricional pré-existente e os episódios podem ter duração mais longa, apresentar maior gravidade e levar essas crianças à morte.

O fato da desnutrição e da anemia terem sido apontadas apenas por duas educadoras não significa necessariamente que esses agravos não sejam relevantes no âmbito da creche, mas talvez sinalize que também as educadoras não consideram as deficiências nutricionais como problemas de saúde. 


\subsection{Conhecimentos e práticas das educadoras em relação à desnutrição}

A partir daqui, serão apresentados os resultados obtidos das entrevistas com as educadoras em relação aos seus conhecimentos e práticas sobre desnutrição.

Os temas foram obtidos a partir de questões norteadoras pré-determinadas no formulário de entrevista. O Quadro 3 apresenta os resultados, de modo esquemático, dividindo-se as questões norteadoras em dois grandes grupos: conhecimentos e práticas. 
Quadro 3. Questões norteadoras e temas relacionados aos conhecimentos e práticas das educadoras em relação à desnutrição.

\begin{tabular}{|c|c|c|}
\hline \multicolumn{2}{|c|}{ Questões norteadoras } & \multirow[b]{2}{*}{$\begin{array}{l}\text { Temas } \\
\text {-É a criança com alimentação inadequada } \\
\text {-É a criança que está abaixo do peso } \\
\text {-É a criança que tem atraso no } \\
\text { desenvolvimento } \\
\text {-É a criança que está sempre doente } \\
\text {-Está relacionada aos cuidados com a mãe no } \\
\text { pré-natal }\end{array}$} \\
\hline Sobre os Conhecimentos & O que é desnutrição & \\
\hline & Causas da desnutrição & $\begin{array}{l}\text {-Falta de alimentação adequada } \\
\text {-Falta de acompanhamento de saúde } \\
\text {-Falta de afeto dos pais }\end{array}$ \\
\hline & Conseqüências da desnutrição & $\begin{array}{l}\text {-Retardo no desenvolvimento } \\
\text {-Retardo no crescimento }\end{array}$ \\
\hline & $\begin{array}{c}\text { Reconhecimento da } \\
\text { desnutrição nas crianças }\end{array}$ & $\begin{array}{l}\text {-Relacionado ao crescimento } \\
\text {-Relacionado ao desenvolvimento } \\
\text {-Relacionado à alimentação } \\
\text {-Relacionado às doenças }\end{array}$ \\
\hline & $\begin{array}{c}\text { Como aprendeu sobre a } \\
\text { desnutrição }\end{array}$ & $\begin{array}{l}\text {-Pela experiência na creche } \\
\text {-Pela experiência de ser mãe }\end{array}$ \\
\hline \multirow[t]{2}{*}{ Sobre as Práticas } & $\begin{array}{l}\text { O que faz quando identifica a } \\
\text { criança desnutrida }\end{array}$ & $\begin{array}{l}\text {-Estimula a alimentação } \\
\text {-Comunica outro profissional da creche } \\
\text {-Estimula a participação nas atividades }\end{array}$ \\
\hline & $\begin{array}{l}\text { O fazer para combater a } \\
\text { desnutrição na comunidade }\end{array}$ & $\begin{array}{l}\text {-Informação aos pais } \\
\text {-Alimentação e acompanhamento de saúde } \\
\text {-Ajuda do governo }\end{array}$ \\
\hline
\end{tabular}

\section{O que é desnutrição?}

A partir das entrevistas, essa questão pôde ser agrupada em 5 temas. O Quadro 4 apresenta esses temas, com os respectivos recortes das falas. 
Quadro 4. O que é desnutrição?

\begin{tabular}{|c|c|}
\hline Temas & Recortes das falas \\
\hline $\begin{array}{c}\text { É a criança com alimentação } \\
\text { inadequada }\end{array}$ & 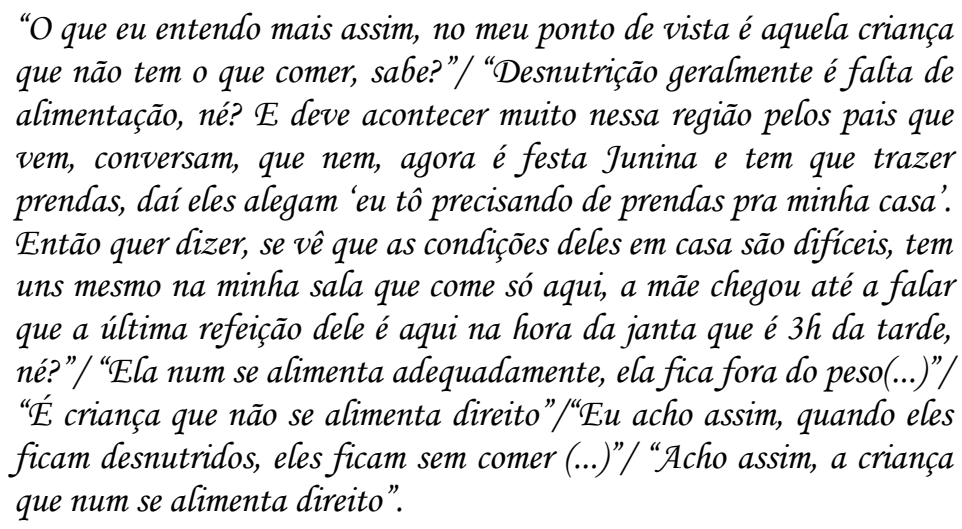 \\
\hline $\begin{array}{c}\text { É a criança que está abaixo do } \\
\text { peso }\end{array}$ & $\begin{array}{l}\text { "Acho que é a criança que tá fora do peso, né?"/ "A parte que eu ouvi } \\
\text { falar é assim, a criança tanto pode ficar inchada ou ficar seca, } \\
\text { gordinha, mas desnutrida" / “(..) magro, baixinho (...)" "Ah, o que eu } \\
\text { sei é que quando a criança se encontra desnutrida ela fica fora do peso } \\
\text { (...)". }\end{array}$ \\
\hline $\begin{array}{c}\text { É a criança que tem atraso no } \\
\text { desenvolvimento }\end{array}$ & $\begin{array}{l}\text { "Uma criança desnutrida você olha e vê que pela idade já era pra ela } \\
\text { tá fazendo aquilo que era pra ser feito na idade que ela tem, por } \\
\text { exemplo: engatinhar, dar as passadinhas, tipo aparência fica meio } \\
\text { apático, fica diferente, né?" / "O desenvolvimento dele é pouco, né? A } \\
\text { criança não se desenvolve muito. Até problemas de aprender, né?". }\end{array}$ \\
\hline $\begin{array}{c}\text { É a criança que está sempre } \\
\text { doente }\end{array}$ & $\begin{array}{l}\text { "é... diarréia, essas coisas, né? Fica mais doentinhos (...)"/ "Ah, o que } \\
\text { eu sei é que quando a criança se encontra desnutrida, a imunidade fica } \\
\text { baixa, éa fica fraquinha, o que eu sei é isso, né? daí acaba adquirindo } \\
\text { mais doenças que as outras". }\end{array}$ \\
\hline $\begin{array}{l}\text { Está relacionada aos cuidados } \\
\text { com a mãe no pré-natal }\end{array}$ & $\begin{array}{l}\text { "Da desnutrição [eu sei] muito pouco, né? Porque entra na parte da } \\
\text { afimentação, desde a gestação, a mãe não se alimenta bem, às vezes } \\
\text { não toma a vitamina que deve tomar dai a criança já nasce } \\
\text { desnutrida, né?". }\end{array}$ \\
\hline
\end{tabular}

Constata-se que as educadoras, individualmente, apresentam uma concepção "reduzida" a respeito da desnutrição. Entretanto, uma leitura dos depoimentos na íntegra revela que, embora fragmentados, todos os aspectos da desnutrição foram contemplados, desde o déficit no crescimento e desenvolvimento até as causas determinantes do problema.

Para a maioria das educadoras da creche, a desnutrição está relacionada a uma alimentação inadequada, representada basicamente pela ingestão insuficiente de alimentos necessários ao crescimento e desenvolvimento da criança. 
Para Batista Filho et al. (1976), o termo desnutrição energético-protéica é adotado como denominação genérica de um grupo específico de deficiências nutricionais, não se resumindo a uma deficiência de proteínas e calorias.

Carraza (1992) define desnutrição energético-protéica ou má nutrição como uma gama de condições patológicas com deficiência simultânea de proteínas e calorias em variadas proporções, que acomete, preferencialmente, crianças de baixa idade e comumente se associa a infecções, sendo os fatores etiológicos mais importantes, o baixo nível sócio-econômico (pobreza-privação nutricional) e seus acompanhantes intrínsecos, as más condições ambientais (infecção - hospitalização) e o baixo nível educacional e cultural (criança negligenciada- falta de amamentação - privação afetiva).

A partir das falas, percebe-se que para as educadoras a desnutrição está relacionada a dificuldades financeiras da família e falta de alimentos em casa, e portanto, é determinada pelas condições de vida a que essas crianças estão submetidas. Laurell (1983) pontua que a instalação de qualquer processo mórbido num corpo biológico está atrelado às condições sociais e econômicas a que uma determinada classe social está inserida. Entretanto, ao atribuir o adoecimento das crianças a determinantes externos à creche, ou seja, às condições de vida e aos cuidados prestados pelos familiares em casa, as educadoras eximem a responsabilidade de seu próprio trabalho na prevenção das doenças, da mesma forma como observado por Maranhão (2000).

Certamente, nas classes sociais mais baixas a precariedade de saneamento básico, alimentação, acesso a serviços de saúde e educação é mais intensa, favorecendo a vulnerabilidade da população infantil às doenças infecciosas e carenciais.

A associação entre desnutrição/infecção destaca-se nos discursos das educadoras, de forma que desnutrição para elas é sinônimo de criança doente. 
Realmente, alguns estudos revelam que a associação desnutrição/infecção é intensa entre crianças que freqüentam creches. Prado et al. (2002), estudando o estado nutricional de crianças em creches, verificaram que as crianças em risco de desnutrição eram as que apresentavam maior frequiência de morbidades, comparadas às eutróficas ou com sobrepeso.

Vários estudos têm evidenciado que condições da nutrição intra-uterina, refletidas no peso ao nascer, constituem determinantes imediatos não só da sobrevivência infantil, como também do estado nutricional nos primeiros anos de vida. Estudo prospectivo realizado no Sul do país indicou que crianças nascidas com baixo peso $(<2.500 \mathrm{~g})$ estavam expostas a um risco onze vezes maior de morrer no primeiro ano de vida e cinco vezes maior de virem a apresentar déficit ponderal no segundo ano de vida (Victora et al., 1987).

Recente estudo de Aerts et al. (2004), que envolveu 3389 crianças com menos de 5 anos, reitera a associação do baixo peso como determinante do retardo no crescimento. Apesar disso, apenas uma educadora conseguiu relacionar a desnutrição com os cuidados pré-natais.

\section{Causas da desnutrição}

O Quadro 5 apresenta os recortes das falas das educadoras que geraram os temas: falta de alimentação adequada; ausência de acompanhamento médico e/ou medicação; e, falta de afeto dos pais. 
Quadro 5. Causas da desnutrição.

\begin{tabular}{|c|c|}
\hline Temas & Recorte das falas \\
\hline Falta de alimentação adequada & $\begin{array}{l}\text { "Geralmente é por não ter alimento, falta de alimentação"/ "Que a } \\
\text { maioria das crianças aqui não tem nem o que comer em casa, né? Vem } \\
\text { na creche mais pra comer mesmo, né?" /"É falta de alimento, falta de } \\
\text { alimentos necessários, né?" / "Acho que passa necessidade em casa, } \\
\text { né? Acho também que tem criança que num come por ela né? Num } \\
\text { tem apetite, mas eu acho que é mais necessidade que a criança passa } \\
\text { em casa" /(...) também talvez seja difícil alimento em casa, pq a mãe } \\
\text { pode não ter tudo em casa (...)" / "Falta de alimentação, as condições } \\
\text { que as crianças moram, dentro de córregos" / "Geralmente é por não } \\
\text { ter alimento, falta de alimentação. Que a maioria das crianças aqui } \\
\text { num tem nem o que comer em casa, né? Vem na creche mais pra comer } \\
\text { mesmo, né?". }\end{array}$ \\
\hline Falta de acompanhamento de saúde & $\begin{array}{l}\text { "Acho que a falta de uma medicação. Porque tem crianças que não } \\
\text { tomam medicação nenhuma. Tem que ter esse acompanhamento. } \\
\text { Por exemplo, quando o bebe nasce tem que tomar aquela vitamina e } \\
\text { tem mãe que num liga pra isso. Acho que isso vai... acho que às } \\
\text { vezes dentro da barriga da mãe, vai ver que num tinha uma saúde } \\
\text { boa, num teve uma alimentação boa, daí o bebezinho nasce já num } \\
\text { tem uma alimentação, ela num faz acompanhamento com } \\
\text { medicação e tudo, né?"/ "(...) às vezes a gente tenta suprir tudo } \\
\text { isso, mas não dá pra curar só com a alimentação, às vezes precisa de } \\
\text { um medicamento, um tratamento mais sério". }\end{array}$ \\
\hline Falta de afeto dos pais & “(...) carinho também né? O carinho dos pais de cuidar direito, né?”. \\
\hline
\end{tabular}

A maioria das educadoras coloca a falta de alimentação adequada como principal causa da desnutrição nas crianças. Como já referido, reconhecem que as condições sócio-econômicas da população que freqüenta a creche são muito precárias, de forma que, muitas vezes, as refeições servidas na creche constituem a única fonte alimentar da criança.

Algumas educadoras relacionam a causa da desnutrição com a falta de um acompanhamento médico adequado e/ou a falta de alguma medicação que a criança e/ou a mãe, na gestação, deveriam tomar.

É evidente que para combater os agravos nutricionais e a morbi-mortalidade infantil são necessárias transformações radicais na estrutura social, política e econômica do país, com melhor distribuição das riquezas, porém a maior efetividade da atuação 
governamental no setor social, é fundamental para atenuar o efeito da renda sobre os determinantes do estado nutricional infantil, como demonstra Monteiro et al. (1992).

A falta de carinho e afeto dos pais para com a criança também foi citada como causa da desnutrição. Embora esse aspecto tenha sido levantado por apenas uma educadora, Silva et al. (1995) observaram componentes depressivos e ansiosos com dificuldade de estabelecimento de vínculos afetivos e sentimento de rejeição em mães de crianças desnutridas, além de responsabilidade unicamente aos pais. Para a autora, interpretar os problemas de saúde dessa forma, sem uma investigação efetiva de seus determinantes, que inclusive podem ser decorrentes da forma como se organizam os cuidados no interior da instituição, dificulta a adoção de medidas de promoção à saúde das crianças e retarda a busca de qualidade nos serviços da creche.

\section{Conseqüências da desnutrição}

Do contexto relativo a essa questão, dois temas foram extraídos das falas das educadoras, para quem a desnutrição tem como conseqüência afetar o desenvolvimento ou o crescimento da criança (Quadro 6).

As educadoras foram quase unânimes em afirmar que a desnutrição afeta o desenvolvimento da criança, embora esse conhecimento seja considerado do senso comum. 
Quadro 6. Conseqüências da desnutrição.

\begin{tabular}{|c|c|}
\hline Temas & Recortes das Falas \\
\hline Retardo no desenvolvimento & 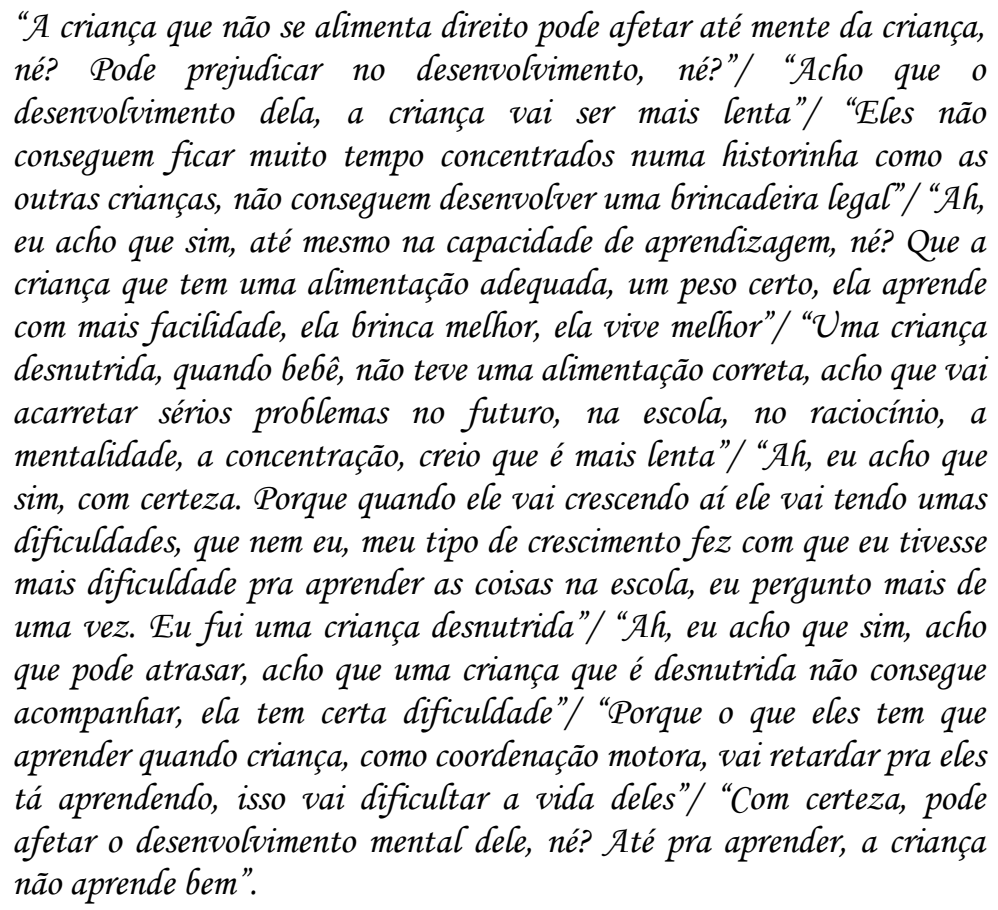 \\
\hline Retardo no crescimento & $\begin{array}{l}\text { "A criança pode num cresce, né?"/ "Com certeza, pode [afetar] no } \\
\text { crescimento dele, né? Pode atingir o crescimento dele". }\end{array}$ \\
\hline
\end{tabular}

O desenvolvimento da criança se processa em ritmo extremamente acelerado nos primeiros anos de vida, e deve, segundo proposta do Ministério da Saúde (2001), ser avaliado periodicamente a partir de alguns marcos. Apesar disso, mesmo profissionais da área da saúde como médicos e enfermeiras da atenção primária, apresentam conhecimentos deficientes sobre desenvolvimento infantil, e não realizam a vigilância do desenvolvimento de forma satisfatória, indicando a necessidade de sensibilizar e capacitar os profissionais para essa prática (Figueiras et al., 2003).

As educadoras é a primeira manifestação detectável da desnutrição, isto é, a consequiência mais visível da desnutrição sobre o organismo da criança. Apesar disso, foi citado somente por duas educadoras. Esse resultado parece estar atrelado a um senso comum cultural de que o tamanho (estatura) da criança depende do tamanho dos pais, 
pois ao se questionar sobre o tamanho da criança, é comum a frase "ela é pequenininha porque os pais também são pequenos e baixinhos".

Todo indivíduo nasce com um potencial genético de crescimento, que poderá ou não ser atingido, dependendo das condições de vida a que a criança esteja submetida desde a concepção até a idade adulta. Assim, o alcance dessa meta biológica depende, da interação entre o potencial genético e a condição ambiental onde se dá o crescimento da criança (Ministério da Saúde, 2001). Dados da Pesquisa Nacional sobre Saúde e Nutrição mostraram que crianças brasileiras do terço superior de renda apresentavam desempenho do crescimento linear, idêntico ao da população de referência (NCHS). Assim, comprovou-se que o potencial genético de crescimento em altura da população brasileira é similar ao de populações de referência, atribuindo-se as diferenças encontradas aos agravos ambientais (INAN, 1990).

\section{Reconhecimento da desnutrição nas crianças (sinais e sintomas)}

Para as educadoras, o reconhecimento de uma criança desnutrida está centrado no crescimento físico, no nível de desenvolvimento neuropsicomotor, na quantidade de alimentos que ela ingere e na freqüência com que fica doente ou não.

No Quadro 7, observa-se que as educadoras reconhecem a desnutrição a partir dos sinais e sintomas, porém estes são utilizados também na definição da desnutrição, ou seja, são as crianças pequenas, magras e baixinhas, que estão sempre doentes, que não conseguem acompanhar as outras crianças nas atividades, ou ainda aquelas crianças sem apetite ou que aparentam não ter o que comer em casa.

Das 15 educadoras entrevistadas, 10 apontaram alguma criança de sua sala como desnutrida, num total de 14 crianças. Dessas, apenas 3 estavam realmente desnutridas, constituindo as únicas 3 crianças da creche com índices antropométricos inferiores a -2 escore Z. Outras 3 crianças encontravam-se em risco de desnutrição, isto é, 
Quadro 7. Reconhecimento da desnutrição nas crianças.

\begin{tabular}{|c|c|}
\hline Temas & Recorte das falas \\
\hline Relacionado ao crescimento & $\begin{array}{l}\text { "Ah, eu vejo assim pela estatura da criança, né? Porque tem criança } \\
\text { que é bem magrinha, nossa! Daí eu vejo mais pela estatura dela" / } \\
\text { "Ah, ela fica magrinha, bem apática" / "Tipo a criança é, eu penso que } \\
e ́ \text { assim, (...) ela tá sempre ab́aixo do peso, ela se alimenta bem, mas } \\
\text { num sei porque não consegue chegar no peso certo, porque a gente vê } \\
\text { pela idade, eu tenho criança com a mesma idade que é bem } \\
\text { desenvolvida, e a outra criança não, ta sempre doentinha, magrinha, } \\
\text { eu penso que é isso a desnutrição (...)" " "Elas são magrinhas, algumas } \\
\text { são baixinhas, tanto magras como baixinhas, e o cabelo da criança é } \\
\text { meio amarelado (...)". }\end{array}$ \\
\hline Relacionado ao desenvolvimento & $\begin{array}{l}\text { "Que nem essa A. mesmo ela fica um pouco assim mais recuada, e as } \\
\text { outras crianças ficam mais soltas, mais abertas" / "Ah, uma criança } \\
\text { que não brinca, muito quietinha, sempre doente" / "...) que da mesma } \\
\text { idade, mas uma se desenvolve bem e outra não, a outra não } \\
\text { acompanha, às vezes até na coordenação é mais atrasadinha mesmo". }\end{array}$ \\
\hline Relacionado à alimentação & $\begin{array}{l}\text { "Eu vejo se ela num ta se alimentando bem, e o tipo de comida que ela } \\
\text { ta comendo (...)" / "...) às vezes eles se alimentam exageradamente, às } \\
\text { vezes, como passam necessidade em casa, chegam aqui e querem comer } \\
\text { mais do que podem, } 2 \text { ou } 3 \text { pratos, mas geralmente as crianças } \\
\text { desnutridas comem pouco, uma ou outra que come demais" / Ah, eu } \\
\text { vejo pela idade dela e também aquela que é difícil de comer, que aqui a } \\
\text { gente não pode tá variando, o que a gente pode fazer é que quando ele } \\
\text { não comeu a gente pega o leitinho ou uma fruta, entendeu?". }\end{array}$ \\
\hline Relacionado às doenças & $\begin{array}{l}\text { "Ah, quando ele num ta comendo, ta dando sempre febre, vômito, } \\
\text { diarréia, ai é quando a gente percebe"/ "(...) ela ta mais gordinha, só } \\
\text { que ela fica mais doente que as outras crianças porque ela é bem } \\
\text { fraquinha, até a voz dela é fraquinha, agora ela ta ficando menos } \\
\text { doente, porque ela ta comendo melhor, a gente a estimula a comer". }\end{array}$ \\
\hline
\end{tabular}

\section{Como aprendeu sobre a desnutrição}

A maioria das educadoras relatou ter aprendido sobre a desnutrição com a experiência na creche, enquanto outras colocaram a experiência de serem mães como facilitadora desse processo. $\mathrm{O}$ Quadro 8 destaca as falas que deram origem a esses temas. 
Quadro 8. Como aprendeu sobre a desnutrição

\begin{tabular}{|c|c|}
\hline Temas & Recortes da s Falas \\
\hline Experiência na creche & $\begin{array}{l}\text { "Aqui mesmo, trabalhando, a gente observando (...)"/ "Aqui mesmo na } \\
\text { creche"/ "Aqui, trabalhando (...)" / "Acho que no dia a dia } \\
\text { trabalhando aqui (...)"/ "(...) porque a gente vai prestando atenção na } \\
\text { criança, a gente tem que prestar atenção pra ver se a criança ta bem } \\
\text { mesmo, porque a gente tem que fazer relatório da criança"/ "(...) e } 5 \\
\text { anos aqui na creche a gente já vai pegando as manhas"/ "Aqui, } \\
\text { trabalhando, com a vida, sei lá!". }\end{array}$ \\
\hline Experiência de ser mãe & $\begin{array}{l}\text { "(..) acho que a convivência com meus filhos" / "Com a vida, com as } \\
\text { minhas crianças (da creche) e com meus filhos, sobrinhos (...)"/ "(..) eu } \\
\text { gosto muito de ler, pesquisar bastante, e assim, eu pesquiso bastante, } \\
\text { quando minha fifha tem algum problema eu vou atrás pra saber tudo } \\
\text { direitinho, por isso que eu aprendo" / "No convivência mesmo, e no } \\
\text { meu caso por eu ser mãe (...)". }\end{array}$ \\
\hline
\end{tabular}

O fato da maioria das educadoras ter obtido conhecimento sobre o assunto, com a própria vivência, seja com as crianças da creche ou com os próprios filhos confirma o pressuposto de baixa qualificação, já apresentado na caracterização das educadoras. Dessa forma, o conhecimento que as educadoras apresentam está basicamente associado às suas concepções de mundo, crenças, costumes e valores que se expressam através do senso-comum (Minayo, 1998).

Realmente, Maranhão (2000), estudando a concepção do “cuidar/educar” para educadoras de uma creche, destaca que a falta de uma definição clara sobre quais atitudes e procedimentos definem o cuidar das crianças no coletivo, atrelada à formação insuficiente das educadoras, pode levá-las a recorrer às suas próprias experiências individuais, tendo como base o próprio trabalho com as crianças, ou a troca de experiências com aquelas que já cuidaram de filhos, sobrinhos e netos, ou que já estão há mais tempo na creche para obtenção de conhecimentos. 


\section{O que faz quando identifica uma criança desnutrida?}

Nesta questão, destacaram-se os seguintes temas: incentiva a alimentação, comunica outro profissional da creche, e estimula a participação nas atividades, conforme apresentado no Quadro 9.

Quadro 9. O que faz quando identifica uma criança desnutrida?

\begin{tabular}{|c|c|}
\hline Temas & Recortes das falas \\
\hline Incentiva a alimentação & $\begin{array}{l}\text { "Olha, a maioria das crianças aqui parece que tem muita fome, né? Daí } \\
\text { a gente deixa a vontade, deixa comer a vontade"/ “...) a gente incentiva } \\
\text { a criança comer, tem criança que não gosta de legume, a criança não } \\
\text { gosta de comer purê, a criança não sabe comer salada. No dia que é } \\
\text { salada a criança não quer comer, a gente fica incentivando"/ "O que a } \\
\text { gente faz, eu procuro estimular a criança a comer, nunca forçar. Eu não } \\
\text { acho certo. Eu tento estimular, canto musiquinha, converso com a } \\
\text { criança sobre a importância dela comer e converso com a mãe pra ela ta } \\
\text { ajudando a gente a estimular a criança a comer, porque é importante pra } \\
\text { criança ela se alimentar bem"/ "Ah, como assim, eu sei que o feijão é } \\
\text { bom daí eu dou o caldinho de feijão, na sala que eu estou. Quando tem } \\
\text { fígado eu dou bastante figado, né? Geralmente aquelas crianças } \\
\text { desnutridas não gostam de comer, né?". }\end{array}$ \\
\hline $\begin{array}{l}\text { Comunica outro profissional da } \\
\text { creche }\end{array}$ & $\begin{array}{l}\text { "Falo pra I., comunico com a mãe que a criança não está se } \\
\text { alimentando" "Ah, eu falo com a I., né? Daí ela toma as providências } \\
\text { dela" / "Ah, eu costumo falar primeiro com a enfermeira, né? Falo pra } \\
\text { ela o problema que ta acontecendo, pra poder chegar na mãe também né? } \\
\text { A gente tem que falar com a pessoa daqui pra depois falar com a mãe, se } \\
\text { ela concordar". }\end{array}$ \\
\hline $\begin{array}{c}\text { Estimula a participação nas } \\
\text { atividades }\end{array}$ & $\begin{array}{l}\text { "Então, dai essas crianças que são mais atrasadas a gente põe pra } \\
\text { trabalhar pra tentar chegar igualar as outras, porque elas são um pouco } \\
\text { diferente, a gente tem que tentar trabalhar mais essas crianças pra } \\
\text { tentar superar essa diferença" "Ah, a gente incentiva ela mais a brincar } \\
\text { com o coleguinha, sempre incentivando, né?". }\end{array}$ \\
\hline
\end{tabular}

Os três temas distintos representam as práticas das educadoras em relação às crianças desnutridas da creche. O incentivo à alimentação, prática mais comum entre as educadoras quando identificam alguma criança desnutrida, e a estimulação da criança nas atividades propostas no grupo, são atitudes relacionadas à uma concepção biológica da desnutrição, ou seja, a concepção de que a desnutrição é causada pela falta de alimentação e tem como conseqüência o atraso no desenvolvimento. Essa prática simplista e restrita à dimensão biológica, apesar de adequada, é paliativa e pode 
dificultar a busca por condições de cuidados mais abrangentes que incluam os determinantes sociais da desnutrição.

Outro aspecto relevante nesta questão, diz respeito à comunicação imediata ao profissional de saúde da creche. Essa atitude demonstra preocupação com a recuperação da criança e respeito pela profissional de saúde, com quem as educadoras parecem partilhar a responsabilidade de cuidar da criança desnutrida. Por outro lado, algumas educadoras parecem atribuir a responsabilidade de cuidar apenas aos profissionais de saúde, não relacionando com as condições e práticas de cuidado do cotidiano que são de sua competência.

Nesse sentido, Maranhão (2000) destaca que a comunicação imediata ao profissional de saúde isenta as educadoras de qualquer atitude e/ou responsabilidade em relação à recuperação das crianças.

Isso ressalta a importância do conhecimento sobre o assunto, para que as ações ocorram de forma homogênea entre os profissionais de saúde, tanto da creche como dos serviços locais, e educadoras, respeitando-se a especificidade de atuação de cada profissional.

\section{O que fazer para combater a desnutrição na comunidade?}

Os principais temas que puderam ser abstraídos das entrevistas nesta questão foram: informação aos pais; alimentação e acompanhamento de saúde; e, ajuda do governo (Quadro 10).

A maioria das educadoras acredita que informação e orientação aos pais a respeito do problema são suficientes para combater a desnutrição. Outras acreditam que um cuidado mais intensivo da alimentação das crianças e um acompanhamento de saúde regular são capazes de combater a desnutrição na comunidade. 
Quadro 10. O que fazer para combater a desnutrição na comunidade?

\begin{tabular}{|c|c|}
\hline Temas & Recortes das falas \\
\hline Informação aos pais & $\begin{array}{l}\text { "Eu faria reuniões pra tá informando os pais, faria bastante reuniões } \\
\text { com os pais né? Porque esses pais é meio assim, né? Daí iria atrás da } \\
\text { família pra ta orientando a família, né?"/ "Chamar os pais pra explicar } \\
\text { pra eles, pq eu acho que é falta de conhecimento também, né?" } \\
\text { "Primeiro tinha que vir aqui pra conscientizar as mães e trabalhar a } \\
\text { importância dos afimentos"/ "(...) então o problema tá na mãe, a mãe } \\
\text { tem que saber que a criança tem que comer todo tipo de legumes, } \\
\text { saladinha, porque comida é costume, se costuma a comer mal, eles vão } \\
\text { ficar a vida inteira comendo mal" / "Passando uns folhetos pros pais, } \\
\text { palestras, porque nem a gente mesmo tem conhecimento, imagine eles } \\
\text { que estão fora assim, né? / "Eu que primeiro daria mais informação, } \\
\text { principalmente é muita falta de informação (...)"/ "Acho que era bom ter } \\
\text { bastante palestra pra conversar com os pais, porque muitos pais não } \\
\text { tem consciência disso, as vezes já vem da gravidez a desnutrição, né?". }\end{array}$ \\
\hline $\begin{array}{l}\text { Alimentação e acompanhamento } \\
\text { de saúde }\end{array}$ & 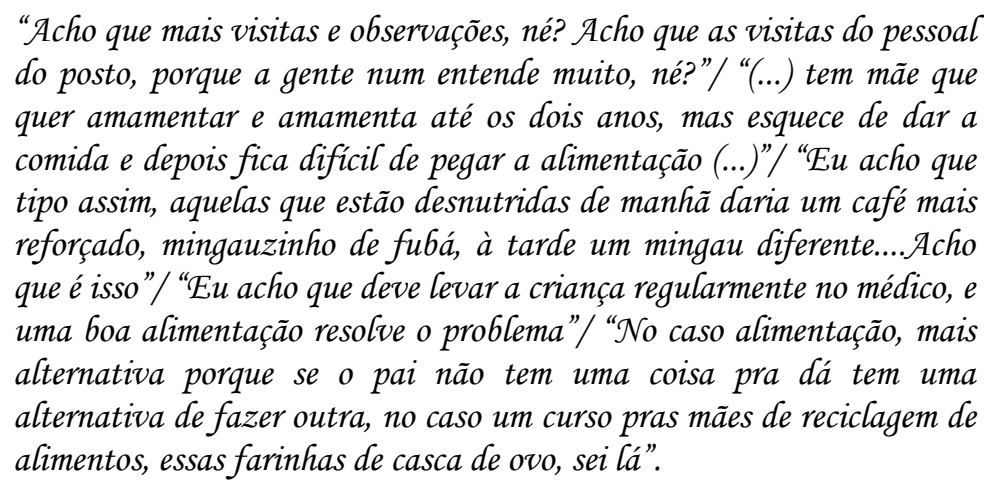 \\
\hline Ajuda do governo & $\begin{array}{l}\text { "Assim, referente a creche, ao meio social, a gente até faz, né? Vm } \\
\text { papel de ajudar as crianças, como aqui já entram crianças } \\
\text { pequinininhas, desnutridinhas, depois saem grandes, fortes, né? Já é } \\
\text { uma ajuda. Agora a ajuda maior que deveria estar sendo feita é do } \\
\text { governo, construir mais creches, mais postos de saúde pra tá } \\
\text { acompanhando as crianças, acho que em termos de ajuda na população } \\
\text { o que poderia ajudar mesmo é mais creches, né? Porque o que ajuda } \\
\text { mesmo são as creches, né?"/ "acho que o governo também devia dar } \\
\text { mais ajuda ao pessoal mais carente que não tem condições de comprar } \\
\text { aqimento, né?". }\end{array}$ \\
\hline
\end{tabular}

Santos et al. (2001), estudou o efeito do aconselhamento nutricional sobre o crescimento de 424 crianças menores de 18 meses de idade, alocadas em dois grupos: um com atendimento usual da rede (grupo controle) e outro com aconselhamento nutricional (grupo intervenção). Os médicos do grupo intervenção foram treinados em aconselhamento nutricional com os guias alimentares, de acordo com a estratégia 
AIDPI, desenvolvida pela OMS/UNICEF, adaptadas para a realidade local. O aconselhamento nutricional teve impacto positivo no crescimento das crianças maiores de 1 ano que ingressaram no estudo: em 180 dias, o ganho de peso foi maior no grupo

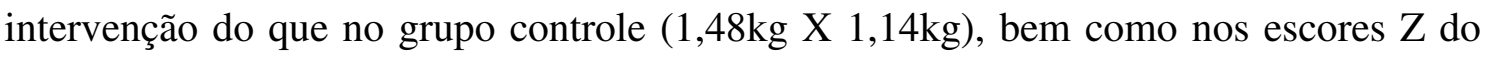
índice peso para idade $(0,25 \mathrm{X}-0,06)$ e peso para altura $(0,40 \mathrm{X} 0,12)$.

Valle et al. (2004) apresentam uma revisão sistemática sobre intervenções nutricionais no crescimento de crianças com menos de dois anos de idade. Os estudos apontam que quando a intervenção utiliza aconselhamento nutricional, há melhora tanto no aporte nutricional, quanto nos percentuais de desnutrição entre as crianças do grupo intervenção, em relação às crianças do grupo controle. Outras melhorias constatadas relacionaram-se às práticas maternas, dieta infantil, redução de anemia e desempenho dos profissionais de saúde.

Esses resultados confirmam que um aconselhamento nutricional pode ser uma medida eficaz para melhorar o estado nutricional de crianças, apesar da desnutrição ser determinada socialmente.

Outro ponto que merece destaque, entre os temas extraídos das falas sobre a questão do combate à desnutrição, é o tema "ajuda do governo". Na concepção de algumas educadoras, o investimento do governo na construção de creches, postos de saúde e programas de alimentação, seria uma medida eficaz para reduzir e recuperar crianças desnutridas.

\subsection{Conhecimentos e práticas das educadoras em relação à anemia}

O Quadro 11 apresenta os temas extraídos das entrevistas com as educadoras a partir das questões norteadoras sobre conhecimentos e práticas em relação à anemia. 
Quadro 11. Temas relacionados aos conhecimentos e práticas das educadoras em relação à anemia.

\begin{tabular}{|c|c|c|}
\hline \multicolumn{2}{|c|}{ Questões Norteadoras } & Temas \\
\hline \multirow[t]{5}{*}{ Sobre Conhecimentos } & O que é? & $\begin{array}{l}\text {-É um problema no sangue } \\
\text {-É uma doença que deixa as crianças fracas } \\
\text {-É uma doença que passa de mãe para filho }\end{array}$ \\
\hline & Causas da anemia & $\begin{array}{l}\text {-Falta de alimentação } \\
\text {-Falta de medicação }\end{array}$ \\
\hline & Consequiências da anemia & $\begin{array}{l}\text {-Pode transformar-se em leucemia } \\
\text {-Pode levar à morte }\end{array}$ \\
\hline & $\begin{array}{l}\text { Reconhecimento da anemia nas } \\
\text { crianças }\end{array}$ & $\begin{array}{l}\text {-Pela cor da pele } \\
\text {-Pelo comportamento } \\
\text {-Pela medicação que toma }\end{array}$ \\
\hline & Como aprendeu sobre a anemia & $\begin{array}{l}\text {-Pela experiência com as crianças da creche } \\
\text { e com os filhos } \\
\text {-Por meio de cursos, treinamento, outros }\end{array}$ \\
\hline \multirow[t]{2}{*}{ Sobre Práticas } & $\begin{array}{l}\text { O que faz quando identifica } \\
\text { uma criança com anemia }\end{array}$ & $\begin{array}{l}\text {-Comunica outro profissional da creche } \\
\text {-Faz algo }\end{array}$ \\
\hline & $\begin{array}{l}\text { O que fazer para combater a } \\
\text { anemia na comunidade }\end{array}$ & $\begin{array}{l}\text {-Informação e orientação aos pais } \\
\text {-Alimentação e acompanhamento de saúde }\end{array}$ \\
\hline
\end{tabular}

Os resultados obtidos a partir dos discursos que geraram os temas são apresentados e discutidos a seguir para cada uma das questões norteadoras, com a construção de quadros em que se destacam os temas que submergiram das falas, da mesma forma como se procedeu em relação à desnutrição.

\section{O que é anemia}

A definição de anemia foi agrupada em 3 temas a partir das entrevistas. O Quadro 12 apresenta os recortes das falas das educadoras que deram origem aos temas.

Para $40 \%(n=6)$ das educadoras a anemia é um problema no sangue causado pela carência de ferro na alimentação e $27 \%(n=4)$ relacionaram a anemia a sinais e sintomas que as crianças apresentam, tais como sonolência, apatia, hipoatividade e palidez cutânea. A transmissão da anemia durante a gestação ou amamentação foi citada por 
$20 \%(n=3)$ delas. É importante destacar que 13\% $(n=2)$ das educadoras afirmaram não saber nada sobre anemia, sendo excluídas dessa parte da entrevista.

Entre as anemias nutricionais, a anemia ferropriva, definida como "estado em que a concentração de hemoglobina no sangue é anormalmente baixa em conseqüência da carência de ferro" (OMS, 1968), parece ser bem difundida no senso comum, uma vez que a maior parte das educadoras relacionou a anemia ao "sangue fraco", algumas até citando a falta de ferro no sangue.

Quadro 12. O que é anemia?

\begin{tabular}{|c|c|}
\hline Temas & Recortes das falas \\
\hline É um problema no sangue & $\begin{array}{l}\text { "É a falta de ferro no sangue, né?" / "Anemia acho que deve ser alguma } \\
\text { coisa no sangue, né?" "Algum problema no sangue que a criança tá } \\
\text { passando, mas eu acho que é o sangue que tá fraco, acho que o sangue } \\
\text { num tá bom, tá fraco,né?" / "...) porque identifica no sangue, né? Não } \\
\text { sei se faltam glóbulos, não sei"/ "Anemia é problema no sangue, agora o } \\
\text { que causa anemia eu não sei"/ "Eu sei que é a falta de ferro, alguma } \\
\text { coisa neste sentido, né?" }\end{array}$ \\
\hline $\begin{array}{c}\text { É uma doença que deixa as } \\
\text { crianças fracas }\end{array}$ & $\begin{array}{l}\text { "Acho que quando uma criança tá anêmica ele tá abatido, né? Tanto na } \\
\text { alimentação como na fisionomia da criança, ele fica abatido, muito } \\
\text { quietinho, num quer se alimentar, acho que com febre" / "...) eu sei que a } \\
\text { pessoa quando tá com anemia ela apresenta muito sono, muita } \\
\text { fraqueza, Só sei que a pessoa fica sonolenta, fraca, só isso que eu sei de } \\
\text { anemia só" / "Olha, sobre anemia eu já sei menos. Apesar de que no } \\
\text { módulo que eu trabalho, lá no berçário, tem um bebê que dorme demais, } \\
\text { daí as meninas falam deve ta com anemia, porque uma das causas é o } \\
\text { sono, a criança dorme muito"/ " (...) aí a mãe conversou com ela pra } \\
\text { levar a menina no médico pq ela tava muito magrinha, muito fraquinha, } \\
\text { pálida, parecia o gasparzinho tal(...)". }\end{array}$ \\
\hline $\begin{array}{c}\text { É uma doença que passa de } \\
\text { mãe para filho }\end{array}$ & $\begin{array}{l}\text { "Olha eu já ouvi falar pq minha menina com } 1 \text { mês deu anemia, pq ela } \\
\text { só mamava no peito, dai acho que eu tava com anemia e passou pra ela, } \\
\text { né?" / Anemia é complicado, pq minha filha sempre foi gordinha e teve } \\
\text { anemia, né? Acho que a anemia eu passei pra ela"/ "(...) também pode } \\
\text { ser hereditário também, né?". }\end{array}$ \\
\hline
\end{tabular}

Os indivíduos portadores de ferrodeficiência, em sua maioria, apresentam manifestações clínicas discretas que podem dificultar a identificação precoce da anemia, como: palidez cutânea, cansaço, capacidade de concentração e aprendizado reduzidos 
(DeMaeyer et al., 1989). Apesar disso, algumas educadoras conseguiram associar a anemia a alguns desses sinais e sintomas.

Outras educadoras, equivocadamente, relacionaram a anemia a um problema de saúde transmissível, ou seja, que a mãe transmite à criança a lactação, ou até de forma hereditária.

Apesar da anemia constituir a principal deficiência nutricional da atualidade e afetar cerca de $43 \%$ das crianças da creche, a análise dos dados revela que as educadoras apresentam um conhecimento do senso comum, baseado em suas próprias experiências pessoais e com conceitos equivocados.

\section{Causas da anemia}

A síntese normal da hemoglobina pode ser comprometida por vários fatores, tais como baixo consumo de alimentos fonte de ferro, infestações parasitárias, doenças infecciosas e genéticas (Barreto, 1992). No entanto, essa abordagem multifatorial apresenta certas limitações para a compreensão do complexo processo de determinação da anemia na população.

Martins et al. (1987), que buscaram caracterizar a determinação da anemia carencial enquanto fenômeno da saúde pública a partir de algumas relações biológicas e sociais, mostraram como as condições para a ocorrência da anemia ferropriva estão atreladas às condições sociais e econômicas de classe, seja pelas deficiências qualitativas e quantitativas da dieta, seja pela precariedade de saneamento ambiental, condições essas típicas das áreas habitadas pelas camadas sociais mais baixas, isto é, a determinação social da anemia pode ser compreendida como resultado de uma espoliação orgânica frente às condições de vida - produção e consumo - em que determinada classe social está inserida. 
Para as educadoras deste estudo, a compreensão das causas da anemia não alcança esse nível de complexidade, ficando ainda muito atreladas ao que Monteiro et al. (2000b) denominam de "determinantes proximais" da anemia. Os autores utilizaram um modelo hierárquico de causalidade como estratégia analítica para determinar a evolução da prevalência da anemia em crianças da cidade de São Paulo. Esse modelo adotou três tipos de determinantes para anemia: proximais, que estariam relacionados às parasitoses intestinais e ao consumo alimentar; intermediários, relativos ao saneamento básico e ao acesso aos serviços de saúde; e, distais, ligados à renda familiar e à escolaridade materna.

Diferentemente do verificado em relação às causas da desnutrição, as educadoras não conseguiram associar a presença da anemia às condições de vida das crianças. Observa-se que para a maioria das educadoras, a causa determinante da anemia nas crianças é a alimentação inadequada ou a falta de alimentação, seguida pela falta de ferro ou vitamina no sangue. Supostamente, para elas, a anemia teria um "agente etiológico" específico, a falta de ferro/vitaminas, seja pela falta de alimentação, seja pela falta de medicação, como apresentado no Quadro 13.

Realmente um consumo alimentar adequado, começando com o aleitamento materno exclusivo até os seis meses e sua manutenção a partir dessa idade, associado posteriormente a uma alimentação complementar quali e quantitativamente apropriada, contribui para manter os níveis de hemoglobina dentro dos parâmetros de normalidade (Assis et al., 2004a).

Entretanto, pesquisa realizada nas capitais brasileiras revelou que a mediana de aleitamento materno exclusivo era de apenas 33 dias (Ministério da Saúde, 2001b). No município de São Paulo, o aleitamento materno exclusivo nos primeiros quatro meses, raramente alcança índices superiores a 30\% (Venâncio et al., 2002). Por outro lado, o 
leite de vaca, na forma líquida ou em pó, que acaba tornando-se a base da alimentação infantil eleva a ocorrência de anemia por apresentar baixa biodisponibilidade do mineral e provocar microhemorragias intestinais se consumido no primeiro ano de vida (LevyCosta \& Monteiro, 2004).

Quadro 13. Causas da anemia.

\begin{tabular}{|c|c|}
\hline Temas & Recortes das falas \\
\hline Falta de alimentação & 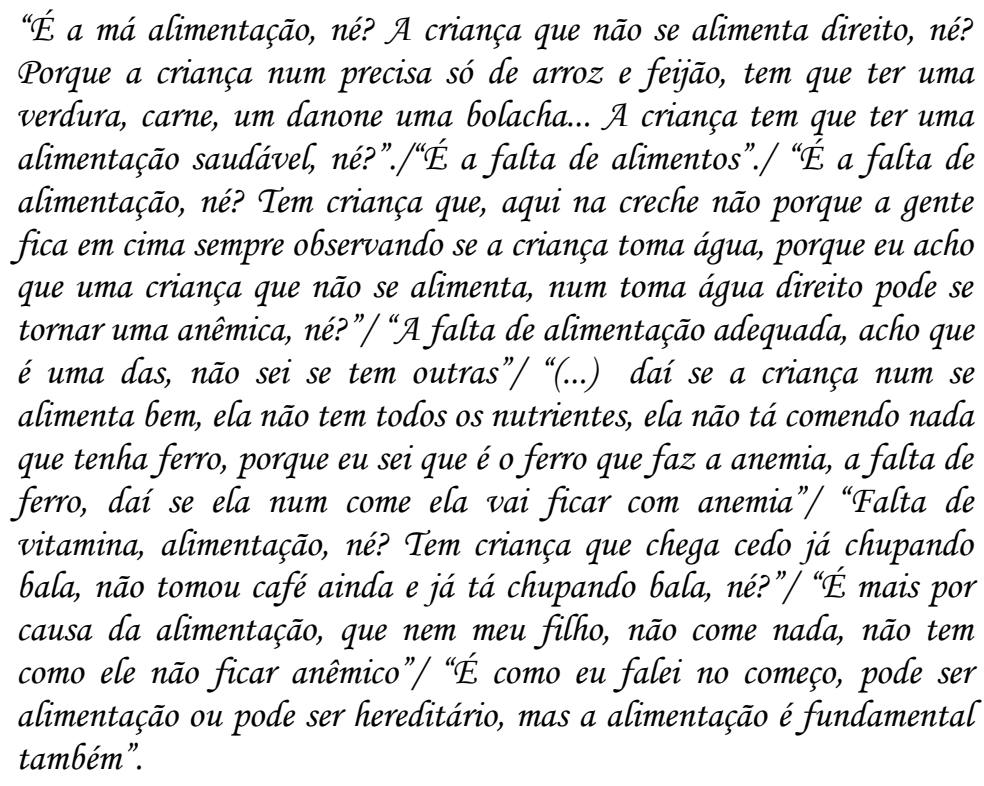 \\
\hline Falta de vitaminas/ferro & $\begin{array}{l}\text { "É a falta de remédios né?"/“Falta de ferro né? Vitamina (..)"/“Não } \\
\text { sei, acho que é alguma coisa no sangue, né? Falta de vitamina no } \\
\text { sangue"/"É a falta de ferro, né" / "Falta vitamina, né". }\end{array}$ \\
\hline
\end{tabular}

Em relação à suplementação de ferro, essa já constitui uma das estratégias preconizadas para combater a anemia ferropriva nos grupos populacionais mais susceptíveis (WHO, 1996). Na cidade de São Paulo, a Secretaria Municipal de Saúde adotou no Programa de Saúde da Família, a estratégia da Atenção Integrada às Doenças Prevalentes na Infância (AIDPI) como protocolo a ser assumido por médicos e enfermeiros capacitados (Secretaria Municipal de Saúde, 2002). Nesse protocolo, o ferro deve ser prescrito a partir do $2^{\circ}$ mês de vida para as crianças prematuras e a partir 
do $6^{\circ}$ mês para as crianças nascidas a termo, de forma continuada até o $24^{\circ}$ mês de vida, em ambos os casos, na dosagem de $2 \mathrm{mg} / \mathrm{kg}$ de peso corporal por dia.

Vale ressaltar ainda que, duas educadoras referiram não saber nada sobre as causas da anemia, além de outras duas que inicialmente foram excluídas dessa parte da entrevista, por afirmarem não saber nada sobre anemia. Assim, para educadoras que cuidam diariamente de um coletivo de crianças, cujo principal problema nutricional é a anemia ferropriva, esse é um dado extremamente relevante a ser considerado e demonstra mais uma vez, a necessidade de educação em serviço.

\section{Conseqüências da anemia para as crianças}

Em relação a essa questão norteadora, dois temas foram extraídos das falas das educadoras, como apresentado no Quadro 14.

Quadro 14. Subcategoria: Consequiências da anemia para as crianças

\begin{tabular}{|c|c|}
\hline Temas & Recortes das falas \\
\hline Pode transformar-se em leucemia & 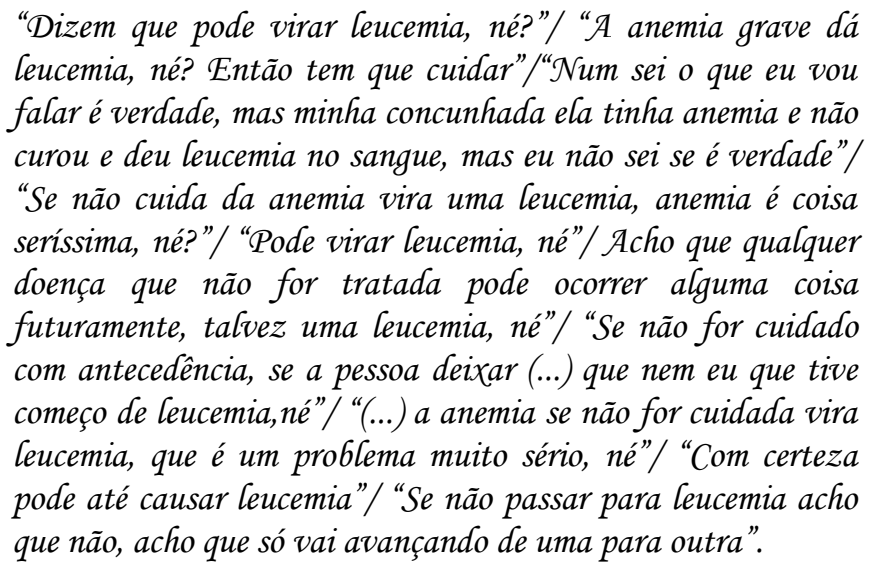 \\
\hline $\begin{array}{c}\text { Pode levar a outros prejuízos para a } \\
\text { criança }\end{array}$ & $\begin{array}{l}\text { "Pode prejudicar tudo, né?" / "Acho que a criança pode até } \\
\text { morrer, né?"/ "Ah, sim com certeza. Principalmente no nosso } \\
\text { berçarinho onde a criança está em desenvolvimento está } \\
\text { começando a engatinhar a andar, eu percebi que há assim um } \\
\text { pequeno atraso, não consegue acompanhar uma criança } \\
\text { normal" / "...) eu penso que pode causar alguma coisa pra } \\
\text { criança, né". }\end{array}$ \\
\hline
\end{tabular}

Dois terços das educadoras responderam que a conseqüência da anemia para a criança é a leucemia, podendo-se dizer que há quase um consenso neste ponto. 
As educadoras reconhecem ainda que a anemia é uma doença muito prejudicial para a criança e que também pode interferir no seu crescimento e desenvolvimento, podendo até levar à morte, segundo algumas.

A leucemia é classificada como um tipo de anemia causada por falta de produção de hemoglobina, decorrente da substituição do tecido hematopoiético normal por um tecido neoplásico, que leva à diminuição da densidade e do número de células hematopoiéticas (Barreto, 1992), ou seja, a leucemia constitui um outro tipo de anemia, que nada tem a ver com a anemia causada pela deficiência de ferro.

O estado anêmico em crianças, por sua vez, realmente representa considerável agravo à saúde, estando associado a maior risco de adoecimento e prejuízos no desenvolvimento psicomotor e cognitivo (DeMaeyer et al., 1989; Walter, 1996; Freire, 1997).

$\mathrm{Na}$ literatura, os dados sobre a relação deficiência de ferro/infecção são conflitantes, com resultados divergentes. Segundo Walter (1996), alguns estudos mostram que uma leve deficiência de ferro é um fator de proteção contra infecções, uma vez que as bactérias necessitam de ferro para seu crescimento. Por outro lado, outros estudos revelam que o déficit de ferro reduz a resposta imune, tornando o organismo mais susceptível às infecções.

O conhecimento das educadoras sobre os efeitos deletérios da anemia é muito importante para que elas se sintam motivadas a combater essa deficiência nutricional na creche.

\section{Reconhecimento da anemia nas crianças (sinais e sintomas)}

Um terço das educadoras referiram não saber reconhecer uma criança com anemia, um quarto referiram reconhecer pelo comportamento da criança, isto é, crianças 
muito quietas e sonolentas. Também reconhecem pela cor da pele, crianças mais pálidas, descoradas. Apenas uma educadora relatou conhecer as crianças com anemia pela medicação que tomam, o sulfato ferroso, conforme apresentado no Quadro 15.

Quadro 15. Reconhecimento da anemia nas crianças (sinais e sintomas).

\begin{tabular}{|c|c|}
\hline Temas & Recortes das falas \\
\hline Pelo comportamento & $\begin{array}{l}\text { "Eu acho que pode ser a } \mathcal{T} \text {., porque ela é muito quietinha, desnutrida, } \\
\text { pequenininha"/"Acho que ser for uma anemia alta, se percebe sim, } \\
\text { porque a criança se comporta diferente das outras, né? Muita } \\
\text { sonolência, num querer brincar, num querer comer, ficar muito quieto, o } \\
\text { verme também, né? Pode ser" "“(..) ele dorme que é uma } \\
\text { maravilha" "Assim, ela fica mais sonolenta, sem muita disposição (...)". }\end{array}$ \\
\hline Pela cor da pele & $\begin{array}{l}\text { "Até a coordenadora fala que acha que ele tem anemia, porque ele é } \\
\text { branco, sabe aqueles brancos, apesar de que a mãe e o pai são brancos, } \\
\text { mas sabe aqueles bem branquinhos? Mas aparentemente você olha pra } \\
\text { ele assim é uma criançona enorme, deve ter nascido de } 7 \text { ou } 8 \\
\text { meses..." /Acho que a cor da pele, às vezes ele fica com os lábios assim } \\
\text { bem pálidos" "Assim, pela cor. A criança bem clarinha, amarela, eu acho } \\
\text { que a M., o K., porque ela é muito palidazinha, porque também tem } \\
\text { criança que é morena e chega a ser amarela, deve ser anemia, não é } \\
\text { possivel que num seja, né?". }\end{array}$ \\
\hline Pela medicação que tomam & $\begin{array}{l}\text { "Eu sei assim pela I. dar o Sulfato ferroso, porque as crianças que } \\
\text { tomam o Sulfato Ferroso têm anemia, né?". }\end{array}$ \\
\hline
\end{tabular}

Estudos realizados em várias regiões do país demonstram que a anemia leve é a forma mais prevalente em nosso meio (Sigulem et al., 1978; Torres et al., 1994; Monteiro et al., 2000b; Osório et al., 2001; Oliveira et al., 2002; Assis et al., 2004a; 2004b). Esse fato justifica a dificuldade em se reconhecer sinais clínicos, que muitas vezes passam desapercebidos pelos próprios profissionais de saúde e pelos pais.

Apesar disso, a maioria das educadoras referiu reconhecer uma criança anêmica a partir de alguns sinais e sintomas como sonolência e cor da pele.

Tendo em vista que o ferro está envolvido na respiração celular, os baixos níveis de hemoglobina interferem no metabolismo energético, podendo afetar o nível de atividade física. No sistema nervoso central, a redução na produção de catecolaminas também provoca alterações no organismo, como apatia, desinteresse, irritabilidade e 
fadiga, o que pode determinar um retardo na capacidade cognitiva da criança. Na pele e nas mucosas, a queda de hemoglobina reflete-se por palidez cutânea, e de mucosas, utilizada para avaliar a presença de anemia em crianças.

O uso do sulfato ferroso como parâmetro para identificar crianças com anemia não é um método seguro, pois seu uso pode ser profilático ou preventivo em menores de 2 anos, como destacado anteriormente.

A maioria das educadoras conseguiu descrever sinais e sintomas da anemia, mas quando solicitadas a identificar alguma criança anêmica, menos da metade conseguiu cumprir essa tarefa. Talvez porque também na creche, a anemia mais prevalente tenha sido a leve (40\%), portanto, de difícil reconhecimento.

Das sete crianças apontadas como possivelmente anêmicas, apenas quatro apresentaram exame recente de sangue, podendo-se comprovar ou não a suspeita das educadoras. Das quatro crianças com exame, nenhuma era anêmica. Por meio da palidez palmar também foram realizadas comparações. Neste caso, apenas uma criança, citada inclusive por duas educadoras, apresentou palidez palmar.

Esses dados revelam que nem sempre as crianças "dorminhocas" e "branquinhas" são anêmicas. O senso comum que permeia o conhecimento das educadoras não é suficiente para um reconhecimento mais preciso da anemia nas crianças, fazendo-se necessário uma distinção de uma criança "dorminhoca" para uma criança hipoativa, e de uma criança "branquinha" para uma criança pálida.

Entretanto, há que se destacar que, detectar a anemia apenas por alguns sinais não constitui tarefa fácil, nem mesmo para profissionais de saúde treinados.

Agências internacionais como a Organização Mundial da Saúde (OMS) e o Fundo das Nações Unidas para a Infância (UNICEF) têm proposto exames baseados em 
critérios e sinais clínicos simples, como palidez palmar e de conjuntivas para triagem da anemia em crianças de 2 meses a 5 anos (Ministério da Saúde, 1999). Entretanto, Spinelli et al. (2003) com objetivo de avaliar a confiabilidade e a validade desses indicadores como métodos para triagem de anemia, realizaram um estudo numa creche municipal com 135 crianças de 3 meses a 6 anos de idade. Foram obtidos os níveis de hemoglobina das crianças através de punção capilar de ponta de dedo e observados os sinais clínicos de palidez palmar e de conjuntivas por uma nutricionista treinada e três funcionárias da creche. Os resultados obtidos, além de indicarem baixa concordância, indicaram também baixa sensibilidade em relação ao diagnóstico da anemia.

Ramos et al. (2004), por sua vez, avaliaram a utilidade da palidez palmar na detecção da anemia em estudo populacional, constatando que essa técnica não foi útil para detectar a anemia na amostra estudada, uma vez que quase a totalidade das crianças apresentou anemia leve.

\section{Como aprendeu sobre a anemia}

Da mesma forma como aconteceu na desnutrição, a maioria das educadoras não recebeu nenhum treinamento sobre o assunto, aprendendo com a própria experiência na creche, ao cuidar das crianças e também a partir da experiência de serem mães. Apenas uma educadora referiu aprendizado a partir de cursos, como demonstra o Quadro 16.

Considerando a elevada ocorrência de anemia na creche e os conhecimentos equivocados e/ou insuficientes apresentados, fica evidente que as educadoras necessitam de capacitação específica sobre o assunto, para que possam prevenir, detectar e controlar essa deficiência nutricional entre as crianças.

Assim, cabe aos profissionais de saúde dos serviços locais e da coordenação da creche instituir medidas de intervenção, na forma de educação continuada, treinamento 
em serviço ou outra ação, que ocupe essa lacuna nos conhecimentos das educadoras e possa, no mínimo, reduzir e controlar a anemia das crianças da creche.

Quadro 16. Como aprendeu sobre a anemia

\begin{tabular}{|c|c|}
\hline Temas & Recortes das falas \\
\hline $\begin{array}{l}\text { Pela experiência com as crianças } \\
\text { da creche e com os filhos }\end{array}$ & $\begin{array}{l}\text { "No dia a dia mesmo, porque também sou mãe e a gente vai } \\
\text { aprendendo" / "Com meus filhos, na consulta que eu levo eles no } \\
\text { médico, aqui que a gente sempre troca informação, né? Daí a I. } \\
\text { sempre explica as coisas pra gente, que a gente sempre tem que dar } \\
\text { comidinha pras crianças direitinho, mas aí a mãe também tem que } \\
\text { saber disso, porque tem mãe que pensa que a criança vive de miojo"/ } \\
\text { "Eu aprendi com as crianças (...)"/ Com a convivência com as } \\
\text { crianças"/ "Aprendi aqui na creche" / "Eu aprendi aqui"/ "Com a } \\
\text { vida mesmo"/ "Com a minha fifha mesmo"/ "Eu aprendi agora com a } \\
\text { minha filha". }\end{array}$ \\
\hline $\begin{array}{l}\text { Por meio de cursos, treinamento, } \\
\text { outros }\end{array}$ & $\begin{array}{l}\text { "Eu aprendi perguntando e lendo, sou uma pessoa bem curiosa"/ } \\
\text { "Lendo, eu sou muito curiosa" / "No escola, informação, os médicos } \\
\text { falam precisa comer alimentos que tem ferro"/ "No curso que eu fiz pra } \\
\text { entra aqui também falou sobre isso". }\end{array}$ \\
\hline
\end{tabular}

\section{O que faz na creche quando identifica alguma criança com anemia?}

Nesta questão destacaram-se os seguintes temas: comunica outro profissional da creche, e, faz algo, conforme o Quadro 17.

De acordo com as falas, a maioria das educadoras, ao suspeitarem que alguma criança apresenta anemia, informam a auxiliar de enfermagem da creche para que providências sejam tomadas, desde comunicação à mãe, até encaminhamento da criança a um serviço de saúde. Apenas $20 \%$ das educadoras tomam suas próprias atitudes, procurando estimular mais a criança nas atividades e observar melhor a alimentação.

Por não conseguirem identificar crianças com anemia, quatro educadoras não foram questionadas sobre suas práticas frente a esse agravo.

Nesse ponto, observa-se que quase um terço das educadoras foram sendo excluídas das questões, no decorrer da entrevista, por não terem conhecimentos mínimos que fizessem com que elas respondessem algo sobre o assunto. 
Quadro 17. O que faz na creche quando identifica uma criança com anemia?

\begin{tabular}{|c|c|}
\hline Temas & Recortes das falas \\
\hline $\begin{array}{l}\text { Comunica outro profissional da } \\
\text { creche }\end{array}$ & $\begin{array}{l}\text { "A gente passa pra I., quando a gente vê algum problema já passa pra I., } \\
\text { né?" / "Ah, não tem o que eu fazer, que nem a I. sempre tá dando o SF } \\
\text { dela, né, cuidando deles com remédio. A gente fala pra I. que a criança } \\
\text { não come, né?"/ "A gente costuma passar pra I., e dai ela toma as } \\
\text { providências, né?"/ "Corro pra I., a gente vê quando não tá comendo, tá } \\
\text { muito páfida, dai ela confere primeiro o que a gente tá falando dai ela dá } \\
\text { o encaminhamento, né?" }\end{array}$ \\
\hline Faz algo & $\begin{array}{l}\text { "A gente faz um cuidado sempre especial, fica olhando se ela tá se } \\
\text { alimentando, o desenvolvimento dela, se ela tá em grupo, se ela tá } \\
\text { brincando, se ela tá quietinha a gente já fica preocupada, a gente fica } \\
\text { sempre observando" "Ah, procuro dar mais alimentação, banho de sol } \\
\text { todos os dias, se der, suco, água e só"/ "Eu pergunto pra mãe se a criança } \\
\text { fez algum exame periódico"/". }\end{array}$ \\
\hline
\end{tabular}

O Boletim Mensal de Saúde da creche, do ano de 2004 (Anexo VIII), apresenta apenas 2 encaminhamentos de criança por motivo de anemia, que foram realizados pela própria pesquisadora na época da coleta de dados.

Isso revela que mesmo que as educadoras comuniquem os casos para a auxiliar de enfermagem da creche, que seria responsável pelo cuidado de saúde mais específico das crianças, nenhuma criança é encaminhada diretamente da creche aos serviços de saúde, em decorrência da anemia.

Os cuidados que as educadoras prestam às crianças que julgam estar com anemia, refletem seus conhecimentos e crenças sobre esse agravo, porém são realizados por uma pequena parcela, fato que indica a necessidade de se programar cursos de reciclagem para que as educadoras possam, pelo menos, estimular corretamente a ingestão de alimentos ricos em ferro e sua associação com alimentos que contribuem para a absorção do ferro. 


\section{O que fazer para combater a anemia na comunidade?}

Nesta questão, dois temas foram abstraídos das falas das educadoras, como se observa no Quadro 18.

Quadro 18. O que fazer para combater a anemia na comunidade?

\begin{tabular}{|c|c|}
\hline Temas & Recortes das falas \\
\hline $\begin{array}{c}\text { Informação e orientação aos pais } \\
\text { sobre alimentação }\end{array}$ & 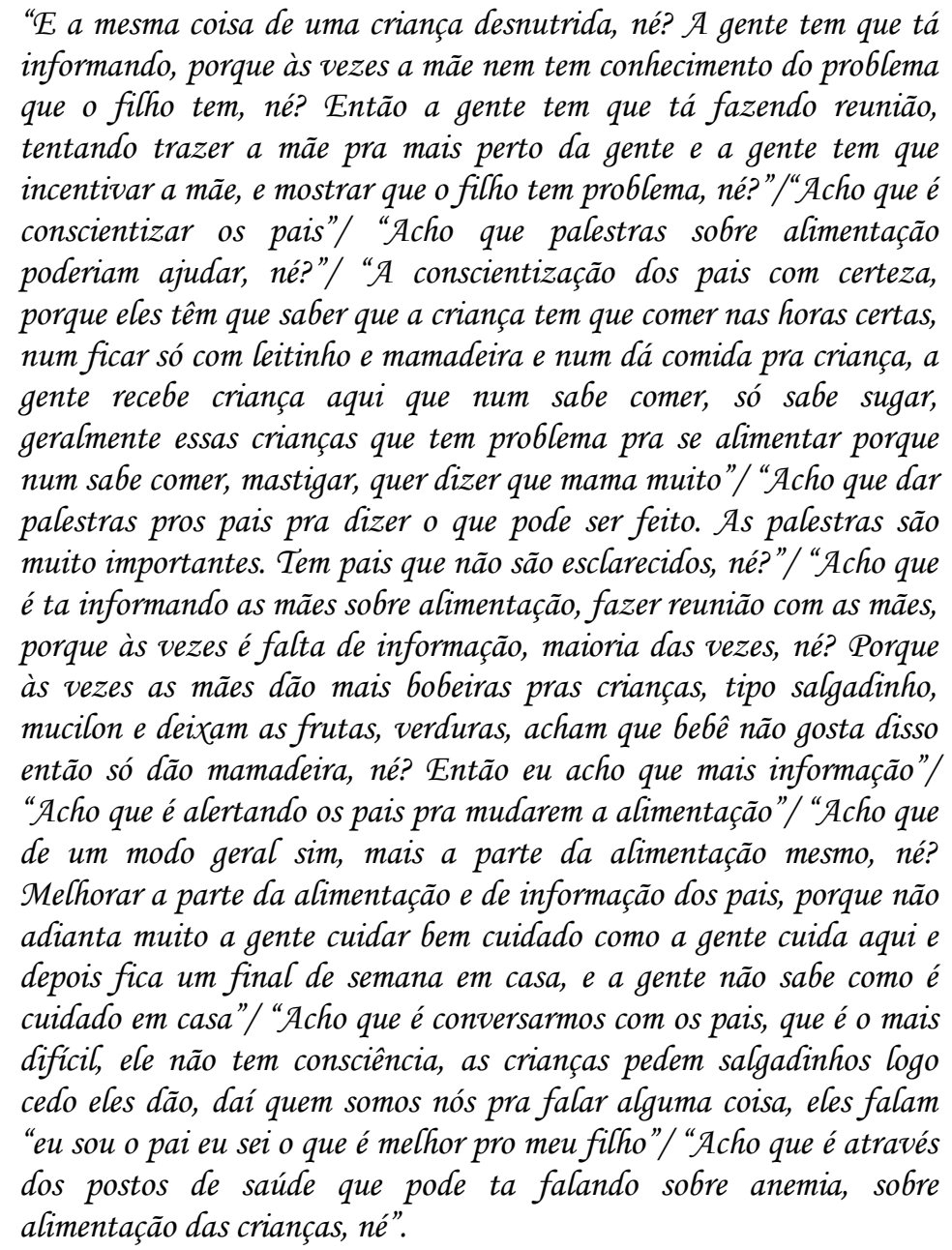 \\
\hline Acompanhamento de saúde & $\begin{array}{l}\text { "Acho que fazer exames pra detectar e daí seria bom a criança tomar } \\
\text { vitaminas, né?" "Acho que mais visitas do posto e sempre observando } \\
\text { as famílias (...) tem que ta pesando e medindo as crianças, né"/ "Isso vai } \\
\text { variar muito, porque tem criança que não come, não adianta, mas } \\
\text { mesmo assim eles tomam o remedinho, e que nem agora meu filho fez o } \\
\text { exame de sangue e não tá dando anemia, mas mesmo assim eu percebo } \\
\text { que ele não se alimenta direito" "Acho que é fazendo exames de sangue } \\
\text { com mais freqüência e orientando mais os pais. Levar a criança mais no } \\
\text { posto, medicação certinha, porque tem mãe que não sabe ver horas. } \\
\text { Então ela falava: é na novela das oito que eu tenho que dar o remédio? } \\
\text { Ela identificava pela televisão, então a criança ir mais no posto, né? } \\
\text { Porque eles vão, vão do jeito deles mas vão". }\end{array}$ \\
\hline
\end{tabular}


$\mathrm{Na}$ concepção das entrevistadas, o problema da anemia poderia ser combatido principalmente por meio de informação aos pais sobre a alimentação da criança. $\mathrm{O}$ acompanhamento de saúde das crianças por meio de medicação e realização de exames, também foi citado como medida de combate à anemia.

No discurso das educadoras fica evidente que para combater e controlar a anemia, a medida mais importante é fornecer informações aos pais relativas à alimentação da criança.

A Organização Mundial da Saúde (DeMaeyer, 1989) coloca como primeira recomendação para o controle e a prevenção das anemias nutricionais, a educação alimentar, seguida da melhoria do saneamento básico e da assistência médica, assim como a criação de programas de suplementação de ferro em doses profiláticas aos grupos de risco.

Alguns estudos mostram que o aconselhamento nutricional tem um impacto positivo sobre o estado nutricional das crianças (Santos et al., 2001; Valle et al., 2004). Assim, as orientações quanto ao aleitamento materno exclusivo até os seis meses de vida, a introdução adequada da alimentação complementar, com a manutenção do aleitamento materno após essa idade devem ser reforçadas, bem como a escolha de uma dieta equilibrada e adequada para cada idade.

A fortificação de alimentos com ferro também pode ser uma medida profilática a médio e longo prazo no combate da deficiência de ferro na população (Bottoni et al., 1997; Fisberg et al., 1999). Entretanto, essa é uma medida preventiva que envolve políticas públicas e exige tempo prolongado de consumo contínuo para que sejam evidenciados seus efeitos. 
No Brasil, o programa de fortificação com ferro das farinhas de trigo e milho, (Brasil, 2002), apresenta uma perspectiva bastante promissora no combate à anemia ferropriva, porém essa perspectiva não aparece nas falas das educadoras.

Tuma et al. (2003) avaliaram o impacto da farinha de mandioca fortificada com ferro em 80 pré-escolares durante 120 dias, na região amazônica do país. Os resultados revelaram que as crianças anêmicas que receberam a farinha de mandioca fortificada foram plenamente recuperadas ao final da pesquisa. Resultados similares foram encontrados por Torres et al. (1995) em 335 crianças menores de 2 anos com o uso de leite em pó integral fortificado com ferro e vitamina C. Após intervenção de 6 meses, os percentuais de anemia entre as crianças reduziram consideravelmente.

Sabe-se que a suplementação medicamentosa também constitui medida profilática importante no combate à anemia, no entanto, essa medida apresenta alguns entraves do ponto de vista operacional. A eficácia dessa intervenção, geralmente, é dificultada por dois fatores: os efeitos colaterais da ingestão de ferro medicamentoso por via oral (náuseas, vômito, cólicas abdominais, obstipação ou diarréia) e a inexistência de sinais e/ou sintomas aparentes que estimulem o uso do sulfato ferroso por um período prolongado.

Torres et al. (1994) estudaram a eficácia da terapêutica com doses profiláticas de sulfato ferroso em 620 crianças de 4 a 36 meses atendidas em duas unidades de saúde do município de São Paulo, constatando melhora do estado nutricional de ferro das crianças, porém, 47,5\% não receberam a medicação corretamente por esquecimento da mãe. Conclui-se que a terapêutica com doses profiláticas de sulfato ferroso, apesar de se mostrar eficiente na recuperação dos níveis de hemoglobina, apresenta sérios entraves do ponto de vista operacional. 
A assistência e o acompanhamento de saúde das crianças, também é uma das medidas recomendadas pela Organização Mundial da Saúde (DeMaeyer, 1989) para combater a anemia na população. Isso significa o acompanhamento desde o pré-natal, com consultas mensais, solicitação de exames periódicos para avaliação da hemoglobina, suplementação com sulfato ferroso e manutenção durante a lactação, orientação alimentar, orientação para o aleitamento materno exclusivo até o sexto mês, e posteriormente, acompanhamento mensal dessa criança durante o primeiro ano de vida, incentivando o aleitamento materno, a introdução oportuna de alimentos, orientando a escolha dos alimentos fonte de ferro, realizando suplementação com sulfato ferroso nos dois primeiros anos de vida, e monitorando a saúde dessa criança de um modo geral.

Para isso, é necessário que se crie uma rede de assistência às crianças, de forma que essa responsabilidade de cuidados e monitoramento, não sejam limitados apenas aos profissionais de saúde, mas também se estendam aos profissionais de creches, aos pais e outros ambientes que prestem cuidados às crianças. 
Considerações finais 


\section{CONSIDERAÇÕES FINAIS}

A proposta deste estudo foi levantar e analisar conhecimentos e práticas de educadoras de uma creche em relação ao estado nutricional das crianças que cuidam, pressupondo-se que seria encontrada uma elevada prevalência de desnutrição e anemia, em virtude da localização da creche estudada, e dificuldade das educadoras em reconhecer e manejar adequadamente crianças com esses distúrbios nutricionais, devido a uma baixa qualificação profissional.

Os resultados relativos à caracterização das crianças mostraram que a maioria havia ingressado na creche devido ao trabalho materno, frequientava a creche há mais 6 meses, vivia com família que percebia menos de 0,5 salário mínimo per capita e possuía cadastro em alguma Unidade de Saúde da Família. Essas informações mostraram que, embora residindo em região de forte exclusão social, as crianças e suas famílias tinham acesso a serviços públicos de saúde, fator que pode modular as condições de saúde das crianças, independente da renda da população.

Os dados relativos à caracterização das educadoras revelaram que a idade média era de 28 anos, a maioria morava na região de Guaianases e possuía filhos. Todas haviam concluído o segundo grau de escolaridade, sendo que 8 haviam cursado o magistério. A maioria não tinha experiência anterior de trabalho em creche e não havia recebido nenhum tipo de treinamento para o trabalho. Contrariando o pressuposto, constatou-se que as educadoras apresentavam boa escolaridade, porém baixa qualificação profissional, com ausência de treinamento específico para o trabalho com crianças, fato que certamente dificulta todo o processo de cuidar e educar, inclusive a prática de prevenir e/ou controlar as deficiências nutricionais mais comuns. 
Quanto ao estado nutricional, a desnutrição não se mostrou um agravo prevalente entre as crianças da creche: apenas 2,7\% apresentaram déficit de peso para idade, $2,0 \%$ déficit de altura para idade e $0,7 \%$ déficit de peso para altura. A anemia, no entanto, afetava $43,3 \%$ das crianças.

O fato das crianças estudadas freqüentarem a creche há pelo menos 6 meses pode justificar em parte a baixa prevalência da desnutrição, pois frequiência a creche tem sido apontada como fator de proteção em relação ao estado nutricional. Outra variável importante que poderia justificar a baixa prevalência da desnutrição é o acesso das crianças aos serviços de saúde, sugerindo que mesmo residindo em áreas de exclusão social, crianças com acesso a serviços de saúde constituem grupo privilegiado no contexto geral da região.

Com relação à anemia, encontrou-se uma prevalência de acordo com o previsto, ou seja, acima de $40 \%$, indicando a urgência de seu controle entre a população infantil, tanto via políticas públicas amplas, como a recente resolução sobre a fortificação de farinhas, quanto por meio de ações específicas do setor da saúde, tais como as parcerias entre unidades locais de saúde e equipamentos sociais, como creches e escolas.

As educadoras apontaram como principais problemas de saúde, os problemas respiratórios e gastrointestinais, ou seja, as deficiências nutricionais não aparecem como problemas de saúde, revelando uma visão distorcida do processo saúde-doença que dificulta a prática de cuidados com a saúde relacionados à promoção e prevenção de doenças. Quanto aos conhecimentos específicos, constatou-se que para as educadoras a desnutrição é caracterizada por crianças pequenas, com atraso no desenvolvimento e que estão sempre doentes; está relacionada, sobretudo, à má alimentação e à falta de um acompanhamento de saúde, tendo como principal conseqüência para a criança, retardo 
no desenvolvimento. Esses conhecimentos foram construídos pela experiência de cuidar de crianças na creche e em casa, ou seja, com os próprios filhos.

Os resultados revelaram que para a maioria das educadoras, a anemia é uma doença no sangue, que pode ser reconhecida pela palidez e hipoatividade; também está relacionada à má alimentação, e tem como consequiência a leucemia. Da mesma forma, tais conhecimentos foram adquiridos no dia a dia, pela vivência de cuidar de crianças na creche e em casa.

Os resultados e as análises obtidas neste estudo permitem concluir que as educadoras possuem conhecimentos superficiais, de senso comum, associados às suas próprias concepções de mundo, costumes, valores e crenças, pois não foram capacitadas nem receberam treinamentos específicos. Muitas apresentaram conceitos errôneos, especialmente em relação a anemia.

Quanto às práticas das educadoras para controlar a desnutrição e a anemia na creche, destacaram-se estimulação à alimentação e à participação nas atividades. Embora fossem capazes de identificar algumas crianças com problemas nutricionais e procurassem contribuir para promover sua saúde, atribuíam aos profissionais e serviços de saúde a responsabilidade por tais ações, não sendo capazes de relacionar com as condições e práticas de cuidado cotidiano na creche, de sua competência.

Para as educadoras, o combate das deficiências nutricionais no âmbito da comunidade não inclui aspectos da determinação social do problema, pautando-se apenas na "educação dos pais", ou seja, em maiores informações aos pais sobre alimentação e acompanhamento de saúde das crianças. Essa perspectiva de conceber o problema de saúde-doença pode dificultar a construção de uma parceria entre educadores e pais em benefício da criança, uma vez que impede a percepção de que os 
problemas são determinados socialmente e não somente decorrentes dos cuidados prestados pela famílias.

O estudo aponta a necessidade de se incluir conhecimentos sobre processo saúde-doença, especialmente anemia e práticas de cuidados com a saúde das crianças, tanto na formação inicial quanto continuada dos educadores infantis. Ao mesmo tempo, indica a importância da parceria entre unidades locais de saúde e creches, com vistas à implementação de ações de promoção à saúde integral da criança. 


\section{Referências bibliográficas}




\section{REFERÊNCIAS BIBLIOGRÁFICAS}

Aerts D, Drachler ML, Giugliani ERJ. Determinants of growth retardation in Southern Brazil. Cad Saúde Pública 2004; 20(5): 1182-1190.

Amaral MFM, Morelli V, Pantoni RV, Rossetti-Ferreira MC. Alimentação de bebês e crianças pequenas em contextos coletivos: mediadores, interações e programações em educação infantil. Rev Bras Cresc Desenvolv Hum 1996; 6 (1/2): 19-33.

Amaral JJF, Menezes AMB, Halpern R, Victora CG, Barros FC. Prevalência e fatores de risco para infecção respiratória aguda em crianças aos seis meses de vida em Pelotas, RS. In: Benguigui Y. Investigações operacionais sobre o controle das infecções respiratórias agudas. OPAS/OMS. Série HCT/AIEPI - 2º ed. Abril, 1997.

Antonio MAGM, Morcílio AM, Piedrabuena AE, Carniel EF. Avaliação nutricional das crianças matriculadas nas quatorze creches municipais de Paulínia -SP. Rev Paulista de Pediatria 1996; 14 (1).

Assis AMO, Barreto ML, Gomes GSS, Prado MS, Santos NS, Santos LMP, Sampaio LR, Ribeiro RC, Oliveira LPM, Oliveira VA. Chidhood anemia prevalence and associated factors in Salvador, Bahia, Brazil. Cad Saúde Pública 2004a; 20(5): 163341.

Assis AMO, Gaudenzi EM, Gomes G, Ribeiro RC, Szarfarc SC, Souza SB. Níveis de hemoglobina, aleitamento materno e regime alimentar no primeiro ano de vida. Rev Saúde Pública 2004b; 38 (4).

Bardin L. Análise de conteúdo. Lisboa, Edições 70, 1979.

Barreto. Como diagnosticar e tratar anemias. Rev Brasileira de Medicina 1992; 49(10): 711-733.

Barros AJD, Gonçalves EV, Borba CRS, Lorenzatto CS, Motta DB, Silva VRL, Schiroky. Perfil das creches de uma cidade de porte médio do sul do Brasil: operação, cuidados, estrutura física e segurança. Cad Saúde Pública 1999; 15 (3): 597-604.

Barros AJD. Child-care attendance and common morbidity: evidence of association in the literature and questions of design. Rev de Saúde Pública 1999; 33(1): 98-106.

Batista Filho M, Sigulem DM, Nóbrega FJ. Nomenclatura e classificação da desnutrição - primeira parte. Jornal de Pediatria 1976; 41(7-8).

Batista Filho M, Rissin A. Deficiências Nutricionais: Ações específicas do setor saúde para o seu controle. Cad Saúde Pública 1993; 9(2): 130-135.

Benício MHA, César CLG, Gouveia NC. Perfil de morbidade e padrão de utilização de serviços de saúde das crianças brasileiras menores de 5 anos - 1989. In: Monteiro 
MFG, Cervini R. Perfil estatístico de crianças e mães no Brasil: aspectos de saúde e nutrição de crianças do Brasil, 1989, Rio de janeiro, IBGE/UNICEF/INAN, 1992.

Bittencourt SA, Magalhães R. Fome: um drama silencioso. In: Minayo MCS. Os muitos Brasis - saúde e população na década de 80. Hucitec, ABRASCO, $2^{\circ}$ ed., 1999.

Bottoni A, Ciolette A, Schmitz BAS, Campanaro CM, Accioly E, Cuvello LCF. Anemia ferropriva. Rev Paulista de Pediatria 1997; 15(3).

Brasil. Constituição da República Federativa do Brasil. São Paulo, Imprensa Oficial do Estado, 1988.

Brasil. Lei n. 9394 de 20 de dezembro de 1996. Lei de Diretrizes e Bases da Educação. Brasília, 1996.

Brasil. Resolução RDC n. 344 de 13 de dezembro de 2002. Áreas de atuação. Alimentos. Legislação específica da área por assunto. Farinhas de trigo e/ou milho fortificadas com ferro. Disponível em http://www.anvisa.gov.br/legis/resol/ 2002/344_02rdc.html. (Acesso em 07 de julho de 2005).

Brown KH. Relações entre infecções gastrointestinais e desnutrição infantil. In: Nestlé Nutrition Workshop series. Nutrição, Imunidade e Infecção na Infância. Programa Pediátrico n.45, Vevey, Suíça, 2001.

Brunken GS, Guimarães LV, Fisberg M. Anemia em menores de três anos que frequientam creches públicas em período integral. J Pediatria 2002; 78(1).

Bueno MB, Marchioni DML, Fisberg RM. Evolução nutricional de crianças atendidas em creches públicas no município de São Paulo, Brasil. Rev Panam Salud Pública 2003; 14(3).

Caldeira AP, França E, Goulart EMA. Mortalidade infantil pós-neonatal e qualidade da assistência médica: um estudo caso controle. J Pediatria 2001; 77(6): 461-8.

Campino ACC. Aspectos sócio-econômicos da desnutrição no Brasil. Rev Saúde Pública 1986; 20(1): 83-101.

Campos MM. Educação infantil: o debate e a pesquisa. Cad Pesq 1997; 101: 113 127.

Campos MM. A mulher, a criança e seus direitos. Cad Pesquisa 1999; 106: 117-127.

Carmo TMD. Pesquisa-ação na relação creche-cuidador familiar em uma instituição comunitária. [Tese]. Ribeirão Preto (SP): Escola de Enfermagem de Ribeirão Preto, Universidade de São Paulo, 2001.

Carraza FR. Distúrbios nutricionais crônicos - Desnutrição. In: Pediatria Básica. São Paulo, Sarvier, 1992. 
Castro AMM, Castro IRR, Branco VMC. A iniciativa "Rio Saudável" no contexto da Promoção da Saúde. Saúde em foco 2002; 23: 9-15.

Chiesa AM. A promoção da saúde como eixo estruturante do Programa de Saúde da Família. I Seminário Estadual: O enfermeiro no Programa de Saúde da Família, São Paulo, 2000.

Chizzotti A. Pesquisa em ciências humanas e sociais. São Paulo: Cortez, 2001.

Conselho Nacional de Credenciamento de creches (Austrália). Priorizando as crianças: sistema de promoção de qualidade e credenciamento. $1^{\circ} \mathrm{ed}, 1993$.

Correa MAS, Gonçalves NNS, Gonçalves A, Leite GPR, Padovani CR. Evolução entre peso e altura e peso e idade em crianças de 3 meses e 6 anos assistidas em creche, Sorocaba (SP), Brasil. Rev Panam Salud Publica 1999; 6(1).

Correa AMS, Gonçalves NNS, Chalita LVAS, Leite GPR, Padovani CR, Gonçalves A. Determinantes da evolução do peso e altura em crianças de 3 meses a 6 anos assistidas em creche: análise por modelo linear não hierarquizado em ensaio quaseexperimental. Rev Panam Salud Publica 2002; 12(1).

DeMaeyer EM, Adiels-Tegman M. The prevalence of anaemia in the world. World Health Stat. Q., 38 (2), 1985.

DeMaeyer EM. et al. Preventing and controlling iron deficiency anaemia through primary healt care. Geneva. WHO, 1989.

Facchini LA. Trabalho materno e ganho de peso infantil. Pelotas, Universitária, 1995.

Farias FTP, Padilha MICS. Educação em saúde: co-participação das educadoras infantis no processo saúde doença no centro de desenvolvimento infantil. Texto e Contexto de Enfermagem 2000; 9(2): 336-347.

Farthing MJG. Anorexia e citocinas na resposta da fase aguda à infecção. In: Nestlé Nutrition Workshop series. Nutrição, Imunidade e Infecção na Infância. Programa Pediátrico n.45, Vevey, Suíça, 2001.

Figueiras ACM, Puccini RF, Silva EMK, Pedromônico MRM. Avaliação das práticas e conhecimentos de profissionais da atenção primária à saúde sobre a vigilância do desenvolvimento infantil. Cad Saúde Pública 2003; 19(6): 1691-99.

Fisberg M, Ferreira AMA, Silva JV, Kliamca PE, Cardoso R, Giorgini E, Faria M, Pedromonico MR, Lemes SO. Nova fórmula láctea infantil: papel na prevenção da anemia carencial. Pediatria, 21 (1), 1999.

Fonseca W, Kirkwood BR, Victora CG, Fuchs SR, Flores JA, Misago C. Fatores de risco para pneumonia em menores de dois anos de idade em Fortaleza, Brasil: um estudo de casos e controles. In: Benguigui Y. Investigações operacionais sobre o 
controle das infecções respiratórias agudas. OPAS/OMS, Série HCT/AIEPI-2, abril, 1997.

Freire WB. Strategies of the Pan American Health Organization/World Health Organization for the control of the iron deficiency in Latin America. Nutr Rev 1997; 55(6): 183-8.

Fuchs SC, Maynart RC, Costa LF, Cardozo A, Schierholt R. Duration of day-care attendance and acute respiratory infection. Cad Saúde Pública 1996; 12(3): 291-96.

Fujimori E, Rezende MA. Assistência/Cuidado à criança com problemas nutricionais. In: Brasil. Instituto para o desenvolvimento da saúde. Universidade de São Paulo. Ministério da Saúde. Manual de Enfermagem. Brasília: Ministério da Saúde, 2001.

Gillespie S, Kevany J, Mason J. Controlling iron deficiency: a report based on an ACC/SCN workshop. Geneva: United Nations/Administrative Committee on Coordination/Subcommittee on Nutrition; 1991.

Goldenberg P. Repensando a desnutrição como questão social. Cortez, 1989.

Gomez F. Desnutricion. Salud Pública de Mexico 2003; 45(supl4).

Guardiola A, Egewarth C, Rotta NT. Avaliação do desenvolvimento neuropsicomotor em escolares de primeira série e sua relação com o estado nutricional. J Pediatria 2001; 77 (3): 189-96.

Guerra CCC, Gomes CET, Carvalho LG, Szauter IH, Rosenfeld LGM, Kanayama RH, Falci M. Prevalência da anemia carencial em crianças albergadas. Boletim 1986; 8 (141).

Haddad L. A creche em busca de identidade. Ed. Loyola, São Paulo, 1991.

Halpern R, Giugliani ERJ, Victora CG, Barros FC, Horta BL. Fatores de risco para suspeita de atraso no desenvolvimento neuropsicomotor aos 12 meses de vida. J Pediatria 2000; 76(6).

Instituto Nacional de Alimentação e Nutrição. Perfil de crescimento da população brasileira de 0 a 25 anos. Pesquisa Nacional sobre Saúde e Nutrição. Brasília, 1990.

Laurell AC. A saúde doença como processo social. In: Nunes EP, (org.) Medicina Social: aspectos históricos e teóricos. São Paulo, Global, 1983.

Lei DLM, Chaves SP, Lerner BR, Stefanini MLR. Retardo do crescimento físico e aproveitamento escolar em crianças do município de Osasco, área metropolitana de São Paulo, Brasil. Cad Saúde Pública 1995; 11(2): 238-45.

Levy-Costa RB, Monteiro CA. Consumo de leite de vaca e anemia na infância no município de São Paulo. Rev Saúde Pública 2004; 38(6): 797-803. 
Lönnerdal B, Dewey KG. Epidemiologia da deficiência de ferro no lactente e na criança. Anais Nestlé, 52, 11-17, 1996.

Luby SP, Kazembe PN, Redd SC et al. Using clinical signs to diagnose anaemia in African children. Bulletin of the World Health Organization 1995; 73(4): 477-82.

Maldonado LA, Castro IRR, Azevedo AMF, Lima EFP, Souza LP, Freire MC, Mendes SR. Avaliação do Projeto "Com Gosto de Saúde": uma iniciativa de promoção da saúde por meio da Educação Nutricional em Escolas. Saúde em Foco 2002; 23: 105-17.

Maranhão DG. O processo saúde-doença e os cuidados com a saúde na perspectiva dos educadores infantis. Cad Saúde Pública 2000a; 16 (4): 1143-8.

Maranhão DG. O cuidado como elo entre a saúde e a educação. Cad Pesquisa 2000b; 111:115-133.

Marins VMRV, Coelho MASC, Matos HJ, Amaral NS, Valle J, Gismondi RC, Almeida RMVR. Perfil antropométrico de crianças de 0 a 5 anos do Município de Niterói, Rio de Janeiro, Brasil. Cad Saúde Pública 1995; 11(2): 246-53.

Martins IS, Alvarenga AT, Siqueira AAF, Szarfarc SC, Lima FD. As determinações biológica e social da doença: um estudo de anemia ferropriva. Rev Saúde Publ 1987; 21: 73-89.

Melchiori LE, Biasoli-Alves ZMM. Crenças de educadoras de creche sobre temperamento e desenvolvimento de bebês. Psicologia Teoria e Pesquisa 2001; 17 (3): 285-292.

Minayo MCS, Sanches O. Quantitativo - Qualitativo: oposição ou complementariedade. Cad Saúde Pública 1993; 9 (3): 239-262.

Minayo MCS. O desafio do conhecimento. São Paulo: HUCITEC, 1998.

Ministério da Educação e Desporto. Censo do Professor. Brasília; 1997.

Ministério da Saúde. Normas para construção e instalação de creches. Brasília, 1989.

Ministério da Saúde. Saúde da Família: uma estratégia para a reorientação do modelo assistencial. Brasília; 1994.

Ministério da Saúde (MS). Atenção Integrada às Doenças Prevalentes na Infância. Avaliar e classificar a criança doente de 2 meses a 5 anos de idade. Curso de Capacitação. Brasília; 1999.

Ministério da Saúde. Acompanhamento do crescimento e desenvolvimento infantil: fundamentos e orientações para profissionais de saúde. Brasília; 2001a. 
Ministério da Saúde. Secretaria de Políticas de Saúde. Área de Saúde da Criança. Prevalência do aleitamento materno nas capitais brasileiras e no Distrito Federal. Brasília, DF; 2001b.

Ministério da Saúde. Os dez passos para uma alimentação saudável: Guia alimentar para crianças menores de 2 anos. Brasília; 2002.

Ministério da Saúde. Agenda de compromissos para a saúde integral da criança e redução da mortalidade infantil. Brasília; 2004.

Miranda AS, Franceschini SCC, Priore SE, Euclydes MP, Araújo RMA, Ribeiro SMR, Netto MP, Fonseca MM, Rocha DS, Silva DG, Lima NMM, Maffia UCC. Anemia ferropriva e estado nutricional de crianças com idade de 12 a 60 meses do município de Viçosa, MG. Rev Nutrição 2003; 16(2): 163-9.

Monteiro CA, Benício MHD’A, Gouveia NC. Saúde e nutrição de crianças brasileiras no final da década de 80. In: Monteiro MFG, Cervini R. Perfil estatístico de crianças e mães no Brasil: aspectos de saúde e nutrição de crianças do Brasil, 1989, Rio de janeiro, IBGE/UNICEF/INAN, 1992.

Monteiro MFG. Baixo peso ao nascer. In: Monteiro MFG, Cervini R. Perfil estatístico de crianças e mães no Brasil: aspectos de saúde e nutrição de crianças do Brasil, 1989, Rio de janeiro, IBGE/UNICEF/INAN, 1992.

Monteiro CA, Conde WL. Tendência secular da desnutrição e da obesidade na infância na cidade de São Paulo (1994-1996). Rev Saúde Pública 2000a; 34(supl.6).

Monteiro CA, Szarfarc SC, Mondini L. Tendência secular da anemia na infância na cidade de São Paulo. Rev Saúde Pública 2000b; 34(supl.6).

Monteiro CA, Mondini L, Souza ALM, Popkin BM. Da desnutrição para a obesidade: a transição nutricional no Brasil. In: Monteiro CA (org.). Velhos e novos males da saúde no Brasil: a evolução do país e de suas doenças. $2^{\circ}$ ed. Hucitec, 2000c.

Moraes MCL. Aspectos de saúde na rotina da creche e o papel do cuidador da criança: relato de experiência. Rev Bras Desenv Hum 1997; 7 (1): 87-92.

Moreira C. Erradicação da pobreza no mundo: uma avaliação das metas no limiar do ano 2000. Observatório da Cidadania, 3, 1999.

Motta MA. A creche: uma instituição a procura de identidade. Rev Bras Cresc Desenv Hum 1996; 6 (1/2): 14-8.

Moysés SJ, Moysés ST, Krempel MC. Avaliando o processo de construção de políticas de promoção da saúde: a experiência de Curitiba. Ciência \& Saúde Coletiva 2004; 9(3): 627-41. 
Neuman NA, Tanaka OU, Szarfarc SC, Guimarães PV, Victora GC. Prevalência e fatores de risco para anemia no Sul do Brasil. Rev Saúde Pública 2000; 34(1).

Nobre LCC. Trabalho de crianças e adolescentes: os desafios da intersetorialidade e o papel do Sistema Único de Saúde. Ciência \& Saúde Coletiva 2003; 9(4): 963-71.

Nóbrega FJ. Desnutrição intra-uterina e pós-natal. São Paulo: Panamed, 1981.

Nóbrega FJ, Campos ALR, Nascimento CFL. Distúrbios Nutricionais e Fraco Vínculo Mãe/Filho. Revinter, 2000.

Oliveira RS, Diniz AS, Benigna MJC, Miranda-Silva SM, Lola MM, Gonçalves MC, Asciutti-Moura L, Rivera MA, Santos LMP. Magnitude, distribuição espacial e tendência da anemia em pré-escolares da Paraíba. Rev Saúde Pública 2002; 36 (1): 26-32.

OMS - Anemias nutricionales. Ginebra, (Série de informes técnicos, n. 405), 1968.

Osório MM, Lira PIC, Batista-Filho M, Ashworth A. Prevalence of anemia in children 6-59 months old in the state of Pernambuco, Brazil. Rev Panam Salud Pública 2001; 10(2): 101-7.

Paine PA, Lisboa AMJ. Fatores que influenciam o baixo rendimento escolar em sobradinho - DF. J Pediatria 1976; 41(7-8).

Paula KA, Palha PF, Protti ST. Intersetorialidade: uma vivência prática ou um desafio a ser conquistado. Interface - Comunicação, Saúde, Educação 2004; 8(15): 331-48.

Prado SRLA, Sigulem DM, Juliano Y, Cury MCFS. Razão de risco de morbidade e estado nutricional em crianças de creche. Rev Paulista de Pediatria 2002; 20(2).

Puffer RR, Serrano CV. Nutritional deficiency and mortality in childhood. Boletín de la Oficina Sanitaria Panamericana 1973; 75: 1-30.

Ramos CA, Fujimori E, Montero RMJM, Minagawa AT, Laurenti D, Oliveira IMV. Utilidade da palidez palmar na detecção da anemia em crianças menores de dois anos. Acta Paulista de Enfermagem 2004; 17(1): 38-44.

Reichenheim ME, Harpham T. Perfil intracomunitário da deficiência nutricional: estudo de crianças abaixo de cinco anos numa comunidade de baixa renda do Rio de Janeiro. Rev Saúde Pública 1990; 24: 69-79.

Rezende MA, Silva CV. Cuidado em creches e pré-escolas utilizando os pressupostos de Mayeroff. Acta Paulista de Enfermagem 2002; 15(4): 73-8.

Rezende MA, Lima FG, Beteli VC, Santos JLF. Habilidades de linguagem e pessoalsocial de crianças de 0 a 3 anos de idade cuidadas em creches. Rev Bras Cresc Desenv Hum 2003; 13(1): 40-52. 
Rezende MA. Uma proposta de cuidado à criança em creches e pré-escolas: a busca de superação dos determinantes históricos e sociais brasileiros. Acta Paulista de Enfermagem 2004; 17(1): 102-7.

Rivera J, Martorell R. Nutrition, Infection and Growth Part I: effects of infection on growth. Clinical Nutrition 1988a; 7: 156-62.

Rivera J, Martorell R. Nutrition, Infection and Growth Part II: effects of malnutrition on infection and general conclusions. Clinical Nutrition 1988b; 7: 163-67.

Rosemberg F. Expansão da educação infantil e processos de exclusão. Cad Pesquisa 1999; 107: 7-40.

Rossetti-Ferreira MC. Políticas de atendimento à criança pequena nos países em desenvolvimento. Cad Pesquisa 2002; 115: 65-100.

Santos LMP, Assis AMO, Baqueiro CM, Quaglia GMC, Morris SS, Barreto ML. Situação nutricional e alimentar de pré-escolares no semi-árido da Bahia (Brasil): I. Avaliação Antropométrica. Rev Saúde Pública 1995; 29(6): 463-71.

Santos I, Victora CG, Martines J, Gonçalves H, Gigante DP, Valle NJ, Pelto G. Nutrition counseling increases weight gain among brazilian children. J Nutrition 2001; 131: 2866-73.

Secretaria Municipal de Saúde. Portaria 3522/2002/SMS- D.O.M. 18/9/2002, pág. 37.

Secretaria Municipal de Saúde. Boletim da Coordenação de Epidemiologia e Informação das Subprefeituras. São Paulo, set/2003.

Shibayama RSV. O conversar com crianças de creches segundo suas educadoras/cuidadoras. [Dissertação]. São Paulo (SP): Escola de Enfermagem da Universidade de São Paulo, 2001.

Sigulem DM, Tudisco ES, Goldenberg P, Athaide MMM, Vaisman E. Anemia ferropriva em crianças do município de São Paulo. Rev Saúde Pública 1978; 12: 16878 .

Silva IF, Campos AL, Nóbrega FJ. Avaliação das características psicológicas de mães de desnutridos internados em enfermaria. Rev Paulista de Pediatria 1995; 13(1): 6-9.

Silva DG, Franceschini SCC, Priore SE, Ribeiro SMR, Szarfarc SC, Sousa SB, Almeida LP, Lima NMM, Maffia UCC. Anemia ferropriva em crianças de 6 a 12 meses atendidas na rede pública de saúde do município de Viçosa, Minas Gerais. Rev Nutr 2002; 15(3).

Silva LSM; Giugliani ERJ; Aerts DRGC. Prevalência e determinantes da anemia em crianças do Porto Alegre, RS, Brasil. Rev Saúde Pública 2001; 35(1): 66-73. 
Silva MV, Sturion GL. Frequência à creche e outros condicionantes do estado nutricional infantil. Rev de Nutrição 1998; 11(1): 58-68.

Silva MV, Ometto AMH, Furtuoso MCO, Pipitone MAP, Sturion GL. Acesso à creche e estado nutricional das crianças brasileiras: diferenças regionais, por faixa etária e classe de renda. Rev Nutrição 2000; 13(3): 193-9.

Silva CS. A escola promotora da saúde na agenda da política do município do Rio de Janeiro. Saúde em Foco 2002; 23: 83-102.

Siviero AA, Anti SMA, Bandeira CRS, Russeff MM, Fisberg M. Intervenção e orientação nutricional no acompanhamento de crianças desnutridas em creches de São Paulo. Rev Paulista de Pediatria 1997; 15(1): 7-13.

Soares NT, Guimarães ARP, Sampaio HAC, Almeida PC, Coelho RR. Estado nutricional de lactentes em áreas periféricas de Fortaleza. Rev Nutr 2000; 13(2): 99106.

Soares NT, Parente WG. Desnutrição e resultados de reabilitação em Fortaleza. Rev Nutrição 2001; 14(2): 103-110.

Souza SB, Szarfarc SC, Souza JMP. Anemia no primeiro ano de vida em relação ao aleitamento materno. Rev Saúde Pública 1997; 31(1): 15-20.

Spinelli MGN, Souza JMP, Souza SB, Sesoko EH. Confiabilidade e validade da palidez palmar e das conjuntivas como triagem da anemia. Rev Saúde Públ 2003, 37(4): 404-8.

Sposati A (org). Mapa da exclusão/inclusão social da cidade de São Paulo. São Paulo: Educ, 1996.

Szarfarc SC, Stefanini MLR, Lerner BR. Anemia nutricional no Brasil. Cad Nutrição 1995; 9: 5-24.

Taddei JA, Cannon MJ, Warner L, Souza P, Vitalle S, Palma D, Nóbrega F. Nutritional gains of underprivileged children attending a day care center in S. Paulo City, Brazil: a nine month follow-up study. Rev Bras Epidemio 2000; 3(1-3): 29-37.

Torres AA, Sato K, Queiroz SS. Anemia em crianças menores de dois anos atendidas nas unidades básicas de saúde no Estado de São Paulo, Brasil. Rev Saúde Pública 1994; $28: 290-4$.

Torres AA, Sato K, Lobo NF, Queiroz SS. Efeitos do uso de leite fortificado com ferro e vitamina $C$ sobre os níveis de hemoglobina e condição nutricional de crianças menores de 2 anos. Rev Saúde Pública 1995; 29(4).

Tuma RB, Yuyama LKO, Aguiar JPL, Marques HO. Impacto da farinha de mandioca fortificada com ferro aminoácido quelato no nível de hemoglobina de préescolares. Rev Nutrição 2003; 16(1): 29-39. 
UNICEF. Situação Mundial da Infância, 1998. Brasília, 1998.

Valle NJ, Santos IS, Gigante DP. Intervenções nutricionais e crescimento infantil em crianças de até dois anos de idade: uma revisão sistemática. Cad Saúde Pública 2004; 20(6): 1458-67.

Vannucchi H, Freitas MLS, Szarfarc SC. Prevalência de anemias nutricionais no Brasil. Cad Nutricionais 1992, 4:7-26.

Venâncio SI, Escuder MML, Kitoto P, Rea MF, Monteiro CA. Freqüência e determinantes do aleitamento materno em municípios do Estado de São Paulo. Rev Saúde Pública 2002; 36(3): 313-8.

Veríssimo MDLOR. O olhar de trabalhadoras de creches sobre o cuidado da criança. [tese] São Paulo (SP): Faculdade de Saúde Pública da USP; 2001.

Veríssimo MDLOR, Fonseca RMGS. O cuidado da criança segundo trabalhadoras de creche. Rev Latino-Americana de Enfermagem 2003; 11 (1): 28-35.

Victora CG, Vaughan JP, Lombardi C, Fuchs SMC, Gigante LP, Smith PG, Nobre LC, Teixeira AMB, Moreira LB, Barros FC. Evidence for protection by breastfeeding against infant deaths from infectious diseases in Brazil. The Lancet 1987; august, 8 .

Victora CG, Gigante DP, Barros AJD, Monteiro CA, Onis M. Estimativa da prevalência de déficit de altura/idade a partir da prevalência de déficit de peso/idade em crianças brasileiras. Rev Saúde Pública 1998; 32(4): 321-7.

Vitória T, Rossetti-Ferreira MC. Processos de adaptação na creche. Cad Pesq 1993; 86: 55-64.

Walter T. Conseqüências não hematológicas da deficiência de ferro. Anais Nestlé, 52: 25-35, 1996.

Weber MW et al. Pallor as a clinical sign of severe anaemia in children: an investigation in the Gambia. Bulletin of the World Health Organization, 75(Sup 1): 113-18, 1997.

WHO. Integrated management of the sick child. Bulletin of the World Health Organization, 1995, 73 (6): 735-40.

WHO. Strategies for the control of iron deficiency in the region. Washington, D.C., 1996.

WHO. Global database on child growth and malnutrition. Geneva, World Health Organization, 1997. 
Woordward B. O efeito da desnutrição energético-proteoca sobre a imunocompetência. In: Nestlé Nutrition Workshop series. Nutrição, Imunidade e Infecção na Infância. Programa Pediátrico n.45, Vevey, Suíça, 2001.

www.prefeitura.sp.gov.br [acessado em 24 de maio, 2004].

Zancan L, Bodstein R. Dlis-Manguinhos como estratégia de Promoção da Saúde. Saúde em Foco 2002; 23: 49-63.

Zucker JR, Perkins BA, Jafari H, Otieno J, Obonyo C, Campbell CC. Clinical signs for the recognition of children with moderate or severe anaemia in western Kenya. Bulletin of the World Health Organization 1997; 75(sup1): 97-102. 
Anexos 
ANEXO I

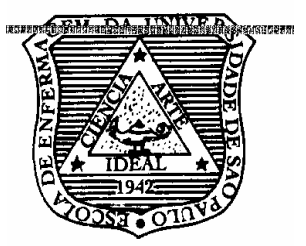

UNIVERSIDADE DE SÃO PAULO

ESCOLA DE ENFERMAGEM

Av. Dr. Eneas de Carvalho Aguiar, 419 - CEP 05403-000

Tel.: (011) 3066-7652 - FAX 3066-7662

C.P. 5751 - CEP 01061-970

Formulário para coleta de dados da criança (entrevista com a mãe) $\mathbf{N}^{\circ}$

IDENTIFICAÇÃO DA CRIANÇA Data da entrevista:

1) Nome :

2) Data de nascimento:

3) Endereço:

4) Área de abrangência da UBS Santa Luzia

$\operatorname{SIM}($ ) NÃO ( )

5) Não, qual?

6) Data de matrícula nesta creche:

7) Motivo de ingresso na creche

( ) Mãe trabalha

( ) Criança com risco nutricional

( ) Família sem condições econômicas

( ) Outras

8) A criança tem outros irmãos matriculados na mesma creche?

$\operatorname{SIM}($ ) NÃO ( ) Se sim, quem?

9) Carteirinha de vacinação atualizada?

$\operatorname{SIM}(\quad) \quad \mathrm{NÃO} \quad(\quad)$

\section{HISTÓRIA DA CRIANÇA E FAMÍLIA}

10) A criança nasceu no tempo SIM ( ) NÃO ( ) 11) Peso ao nascer:

12) Fez pré-natal SIM ( ) NÃO ( )

13) A criança (nome da criança) foi amamentada? $\quad$ SIM ( ) NÃO ( )

14) Se sim, ainda mama? $\quad \operatorname{SIM}($ ) NÃO ( )

15) Mamou ontem? SIM ( ) NÃO ( )

16) Se não, até qual idade?_____ (meses)

17) Com que idade (dias ou mês) começou a dar água?

18) Com que idade (dias ou mês) começou a dar chá? 
19) Coloca açúcar no chá?

$\operatorname{SIM}(\quad) \quad \mathrm{NÃO}(\quad)$

20) Com que idade (dias ou mês) começou a dar outros alimentos (suco/frutas/leite/ mingau/papinha)?

21) Quantas pessoas moram na casa (parentesco com a criança)?

22) Quem trabalha e quanto ganha?

\begin{tabular}{|l|l|l|}
\hline Parentesco com criança & O que faz & Quanto ganha (R\$) \\
\hline & & \\
\hline & & \\
\hline & & \\
\hline & & \\
\hline
\end{tabular}

\section{DADOS RELATIVOS À MORBIDADE}

23) A criança adoeceu nos últimos 15 dias?

SIM ( ) NÃO ( ) Sinais/ Sintomas:

24) Costuma ir ao posto de saúde? $\quad$ SIM ( ) NÃO ( )

25) Se sim, qual?

26) Se sim, qual o motivo para ir ao posto de saúde?

27) Sem sim, qual foi a última vez que procurou o posto de saúde?

28) A criança já ficou internada alguma vez?

$\operatorname{SIM}($ ) NÃO ( )

29) Se sim, quando?

30) Se sim, porque?

31) Está fazendo uso de alguma medicação/vitamina? $\quad$ SIM ( ) NÃO ( )

32) Se sim, qual?

33) Já teve anemia? SIM ( ) NÃO ( ) Não sabe ( ) 
34) Se sim, como descobriu?

de sangue ( ) Outra resposta ( ) qual?

35) Se já teve anemia, qual era a idade da criança?

36) Tratou a anemia? $\quad \operatorname{SIM}($ ) NÃO ( )

37) Ainda está em tratamento? SIM ( ) NÃO ( )

38) Se sim, Como tratou ou está tratando? com alimento ( ) com remédio ( )

39) Se com remédio, qual? por quanto tempo? 


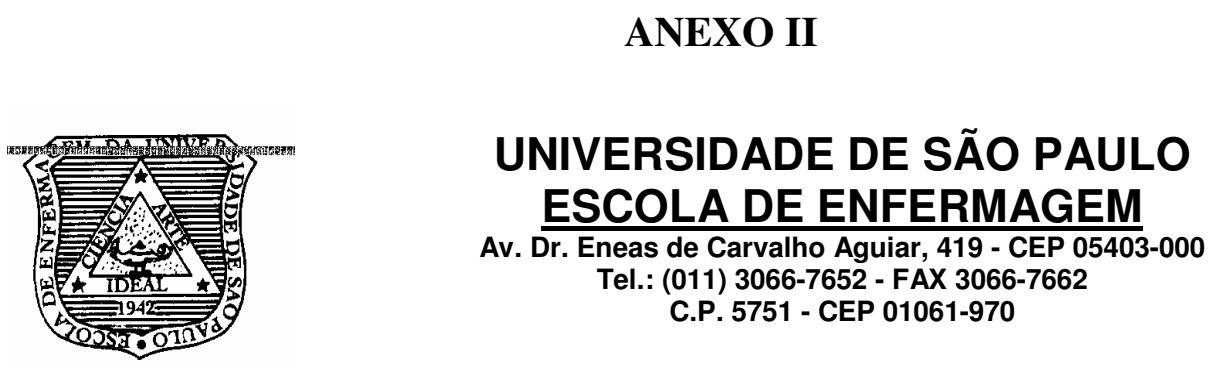

Formulário para coleta de dados das educadoras

\section{IDENTIFICAÇÃO DA EDUCADORA}

Data da entrevista: $N^{o}$ da entrevista:

1)Nome:

2)Idade: anos 3) Região de moradia

4) Profissão:

5) Função exercida:

6) Escolaridade (anos de estudo completos):

7) Tem filhos? NÃO ( ) SIM ( ) Quantos e idade de cada um

8) Há quanto tempo trabalha nesta creche?

9) Com qual grupo etário trabalha nesta creche no momento?

10) Já tinha experiência de trabalho em creches?

NÃO ( ) SIM ( ) Quanto tempo?

11) Recebeu algum treinamento específico para trabalhar na creche?
NÃO ( ) SIM ( )
Onde?

12) Você já cuidou de crianças (filhos/outros)? 


\section{DADOS RELATIVOS À DESNUTRIÇÃO}

1) Quais os principais problemas de saúde que você identifica na creche?

2) Quais os principais problemas nutricionais que você identifica na creche?

3) O que você entende por desnutrição? ( Já ouviu falar/ sabe algo sobre?)

4) Como você percebe que uma criança está desnutrida?

5) Das crianças que você cuida, quais você acha que estão desnutridas? Por quê?

6) Você consegue perceber alguma diferença entre as crianças desnutridas e as outras crianças? Quais?

7) Você acha que a desnutrição pode acarretar problemas ou conseqüências para a criança? Quais?

8) Como você obteve esses conhecimentos?

9) $\mathrm{O}$ que você costuma fazer aqui na creche quando identifica uma criança desnutrida?

10) $\mathrm{O}$ que você acha que causa a desnutrição nas crianças?

11) Quais medidas você acha importante tomar no âmbito coletivo (familiares, bairro, município) para evitar a desnutrição de forma geral?

\section{DADOS RELATIVOS À ANEMIA}

1) O que você entende por anemia?

2) Das crianças que você cuida, quais você acha que têm anemia? Por quê?

3) Você consegue perceber alguma diferença entre as crianças com anemia e as outras crianças? Quais?

4) Você acha que a anemia pode acarretar problemas ou conseqüências para a criança? Quais?

5) O que você costuma fazer aqui na creche quando identifica uma criança com anemia?

6) O que você acha que causa anemia nas crianças?

7) Como você obteve esses conhecimentos?

8) Quais medidas você acha importante tomar no âmbito coletivo (familiares, bairro, município) para evitar a anemia de forma geral? 


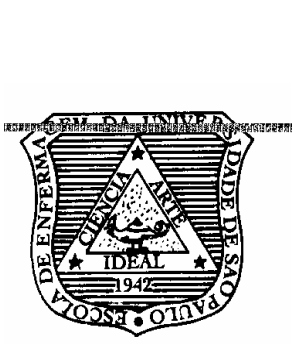

\author{
ANEXO III \\ UNIVERSIDADE DE SÃO PAULO \\ ESCOLA DE ENFERMAGEM \\ Av. Dr. Eneas de Carvalho Aguiar, 419 - CEP 05403-000 \\ Tel.: (011) 3066-7652 - FAX 3066-7662 \\ C.P. 5751 - CEP 01061-970
}

São Paulo, de de 2004

Exma. Sra.

Clarisse Viena da Silva

DD Diretora da Creche Pq. São Jorge

Prezada senhora,

Vimos através desta solicitar autorização para o desenvolvimento da pesquisa científica denominada "Estado nutricional de crianças: conhecimentos $e$ práticas de educadoras de uma creche" que gostaríamos de realizar nesta creche. Esclarecemos que a realização deste trabalho faz parte das exigências do Curso de Pós-Graduação, Nível Mestrado, da Escola de Enfermagem da Universidade de São Paulo. Esta pesquisa tem como objetivo conhecer o estado nutricional das crianças da creche, assim como os conhecimentos e práticas das educadoras em relação à desnutrição e anemia, tendo em vista constituírem problemas importantes de saúde coletiva.

Para isso necessitamos captar dados de caracterização das crianças, bem como verificar o peso e a estatura. Também haverá necessidade de entrevistar individualmente as educadoras e os pais das crianças.

$\mathrm{O}$ estudo permitirá compreender melhor a ocorrência desses problemas e fornecer subsídios para o desenvolvimento de propostas de intervenção que conduzam à melhoria das condições nutricionais de crianças usuárias de creches. Outrossim, salientamos que esta pesquisa não trará nenhum prejuízo ou risco para as crianças e educadoras da creche, requerendo apenas disponibilidade de tempo.

O projeto será submetido a um Comitê de Ética em Pesquisa e todos os aspectos ético-legais serão contemplados conforme a Resolução 196/96, incluindo os termos de consentimento livre e esclarecido tanto para pais quanto para as educadoras, sendo, portanto, a participação na pesquisa, totalmente livre e voluntária.

Comprometemo-nos e garantimos o fornecimento de todas as informações que se fizerem necessárias, pessoalmente ou através do telefone/fax acima discriminado.

Agradececendo antecipadamente a atenção e colaboração, aproveitamos a oportunidade para reiterar nossos protestos de estima e consideração.

Atenciosamente,

Cláudia Nery Teixeira Palombo

Enfermeira - Pós-graduanda

Prof ${ }^{a}$ Dra. Elizabeth Fujimori

Orientadora 


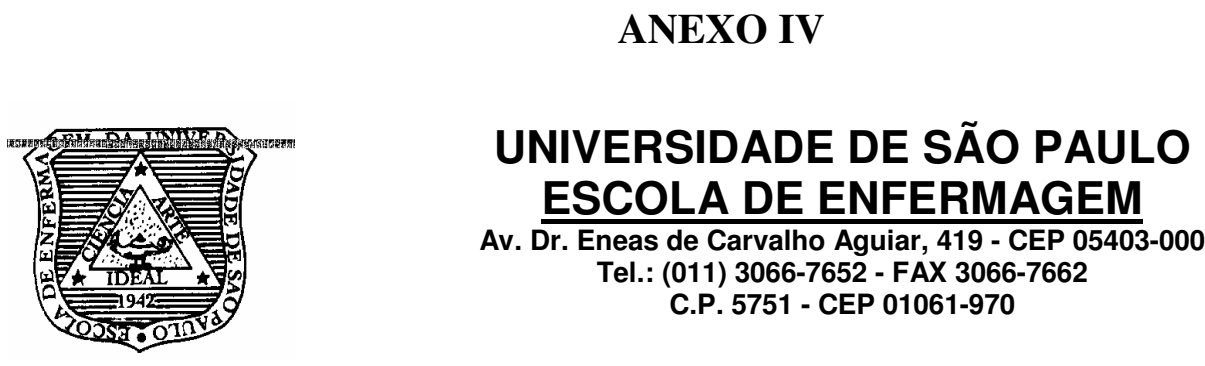

\section{TERMO DE CONSENTIMENTO LIVRE E ESCLARECIDO}

\section{$\underline{\text { Aos Pais/Responsáveis }}$}

Meu nome é Claudia Nery Teixeira Palombo, sou enfermeira e, como estudante do curso de pós graduação (mestrado) da Escola de Enfermagem da USP, sob supervisão da Prof. Dra Elizabeth Fujimori, estou realizando uma pesquisa nesta creche com o objetivo conhecer e avaliar as condições nutricionais das crianças menores de 5 anos e os conhecimentos e práticas das educadores em relação à desnutrição e anemia.

O seu filho (a) está sendo convidado a participar da pesquisa. Para isso, necessitamos que a Sra. autorize a verificação do peso e da altura de seu(s) filho(s), bem como, traga o resultado do último exame de sangue realizado (se tiver) para que possamos identificar se seu filho está/ou já teve anemia.

A Sra. receberá as devidas informações e orientações sobre os achados e, caso seja necessário, o devido encaminhamento para o Serviço Municipal de Saúde.

Garantimos o fornecimento de todas as informações que se fizerem necessárias, pessoalmente ou através do telefone/fax acima discriminado, antes e durante todo o curso da pesquisa.

Os dados obtidos serão confidenciais e só serão divulgados nos meios científicos. Caso a Sra. não queira que seu filho participe da pesquisa, ou queira desistir em qualquer momento, garantimos que não sofrerá nenhum tipo de prejuízo e/ou constrangimento.

$\mathrm{Eu}$,

voluntariamente, após ter recebido todas as informações necessárias de forma clara, concordo que meu filho participe dessa pesquisa.

São Paulo, / 2004. 


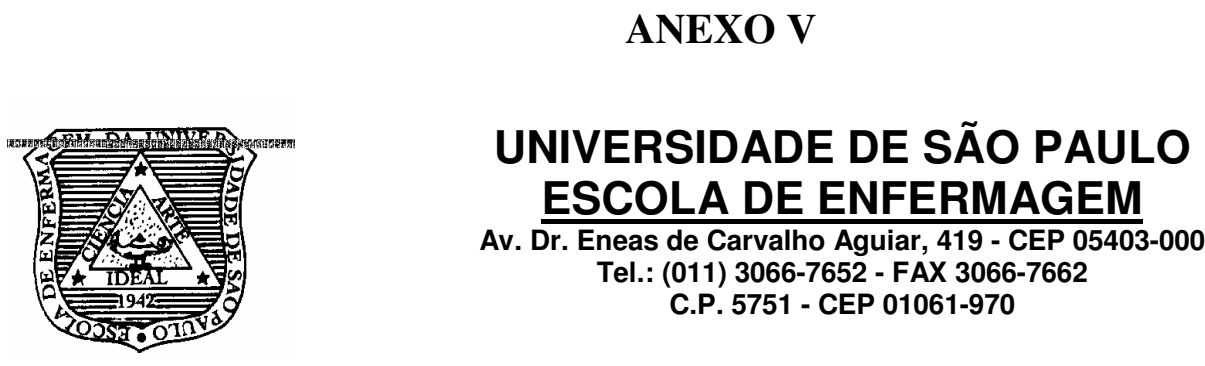

\section{TERMO DE CONSENTIMENTO LIVRE E ESCLARECIDO}

\section{$\underline{\text { Às Educadoras }}$}

Meu nome é Claudia Nery Teixeira Palombo, sou enfermeira e, como estudante do curso de pós graduação (mestrado) da Escola de Enfermagem da USP, sob supervisão da Prof. Dra Elizabeth Fujimori, estou realizando uma pesquisa nesta creche com o objetivo caracterizar as condições nutricionais das crianças e os conhecimentos e práticas dos educadores em às principais deficiências nutricionais.

A Sra está sendo convidada a participar desta pesquisa, que será realizada por meio de entrevista individual (duração média de 20 minutos) que será gravada e depois transcrita e analisada para levantar os conhecimentos e práticas dos educadores em relação à desnutrição e anemia.

Garantimos o fornecimento de todas as informações que se fizerem necessárias, pessoalmente ou através do telefone/fax acima discriminado, antes e durante todo o curso da pesquisa.

Os dados obtidos serão confidenciais e só serão divulgados nos meios científicos. Caso a Sra. não queira participar da pesquisa, ou queira desistir em qualquer momento, garantimos que não sofrerá nenhum tipo de prejuízo e/ou constrangimento. A Sra tem também total liberdade para retirar seu consentimento a qualquer momento da pesquisa, sem que isso implique em penalização.

$\mathrm{Eu}$,

voluntariamente, após ter recebido todas as informações necessárias de forma clara, concordo em participar dessa pesquisa.

São Paulo, / 2004. 


\author{
ANEXO VI \\ UNIVERSIDADE DE SÃO PAULO \\ ESCOLA DE ENFERMAGEM \\ Av. Dr. Eneas de Carvalho Aguiar, 419 - CEP 05403-000 \\ Tel.: (011) 3066-7652 - FAX 3066-7662 \\ C.P. 5751 - CEP 01061-970
}

\title{
RESULTADOS
}

Por ocasião da coleta de dados para a amostra da pesquisa "Estado nutricional de crianças: conhecimentos e práticas de trabalhadoras de uma creche”, os achados encontrados na avaliação da(o) , de acordo com os critérios estabelecidos no projeto e sumariamente descritos, ao final deste impresso, foram:

1. Peso : gramas.

Valor: ( )normal ( )anormal para a idade.

2. Altura : centímetros.

Valor: ( )normal ( )anormal para a idade.

São Paulo, / 2004

Profissional responsável 
ANEXO VII

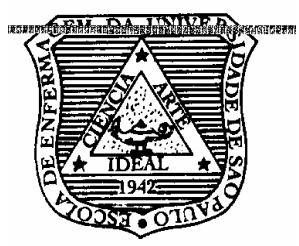

\section{UNIVERSIDADE DE SÃO PAULO}

ESCOLA DE ENFERMAGEM

Av. Dr. Eneas de Carvalho Aguiar, 419 - CEP 05403-000

Tel.: (011) 3066-7652 - FAX 3066-7662

C.P. 5751 - CEP 01061-970

\section{FICHA DE ENCAMINHAMENTO}

São Paulo , de de 2004

PARA:

NOME:

DN: I__

IDADE: anos e/ou meses

SEXO: ( )M ( )F

NOME DA MÃE OU RESPONSÁVEL:

Por ocasião da coleta de dados para a amostra da pesquisa "Estado nutricional de crianças: conhecimentos e práticas de trabalhadoras de uma creche", de acordo com o projeto supra citado, encaminhamos o paciente para avaliação e conduta pertinentes à área de saúde.

Motivo do encaminhamento:

Profissional responsável 